\title{
Marcela Freire Rangel
}

\section{Variações sobre 0 preto e o negro na pintura moderna}

Tese apresentada ao Programa de Pós-Graduação em Artes, Área de Concentração: Artes Plásticas, Linha de Pesquisa: Poéticas Visuais, da Escola de Comunicações e Artes da Universidade de São Paulo, como exigência parcial para obtenção do Título de Doutor em Artes, sob a orientação do Prof. Dr. Marco Garaude Giannotti 
Marcela Freire Rangel

\section{Variações sobre o preto e o negro na pintura moderna}

Tese apresentada ao Programa de PósGraduação em Artes, Área de Concentração: Artes Plásticas, Linha de Pesquisa: Poéticas Visuais, da Escola de Comunicações e Artes da Universidade de São Paulo, como exigência parcial para obtenção do Título de Doutor em Artes, sob a orientação do Prof. Dr. Marco Garaude Giannotti 


\section{Observação: As imagens não disponíveis na versão digital do trabalho}


Membros da Banca Examinadora

Prof. Dr.

Prof. Dr.

Prof. Dr.

Prof. Dr.

Orientador: Prof. Dr. Marco Garaude Giannotti. 



\section{Resumo}

Esse estudo trata de seis variações do preto na pintura. $O$ trabalho apresenta telas de Edouard Manet, Vincent van Gogh, Henry Matisse, Iberê Camargo, Eduardo Sued e Pierre Soulages.

A pesquisa das obras e procedimentos poéticos desses pintores visa a indicar para diversas maneiras como o preto, não mais usado para 0 sombreado, se transforma em áreas de cor e como esses campos cromáticos atuam nas pinturas.

A análise mostra que a cor preta, na qual há variações de tonalidade e saturação, pode ser usada como um meio de tensão cromática na superfície pictórica, como um elemento expressivo, ou para criar uma nova espacialidade para além do plano do quadro. Vale a pena notar que esses usos não são mutuamente exclusivos e, por exemplo, o preto que cria a tensão cromática pode ser expressivo e criar uma nova espacialidade.

Palavras chave: pintura moderna, cor preta, Edouard Manet, Vincent van Gogh, Henry Matisse, Iberê Camargo, Eduardo Sued, Pierre Soulages 


\begin{abstract}
This essay deals with six variations of black in painting. Reaserch on the production and poetic procedures by Eduoard Manet, Vincent van Gogh, Henry Matisse, Iberê Camargo, Eduardo Sued and Pierre Soulages, indicates several manners where black, contrary to it's use as a shadowing component, transforms itself in areas of color.

The manner in which the cromatic fields act upon the painting is analised and show that the color black, with it's variations in tone and depth, may be used as an element of expession; as a means for chromatic tension over the picture's surface or for the production of a new spaciality beyond it's surface.

These uses are not mutually exclusive and, as where black creates chromatic tension, it may also be expressive and generate a new spaciality.
\end{abstract}

Key words: modern painting, color black, Edouard Manet, Vincent van Gogh, Henry Matisse, Iberê Camargo, Eduardo Sued, Pierre Soulages 


\section{Agradecimentos}

Uma tese é um trabalho individual que se torna exeqüível graças à colaboração de diversas pessoas. Essa pesquisa não seria possível sem a atenção e informações dadas por Eduardo Sued, todas as vezes que eu the procurei, nem sem a acolhida e apoio de Elisa Malcon, Lisiane Antunes Cardoso, Giovanna Ellwanger (Equipe de Catalogação e Pesquisa), Eduardo Haesbaert (Equipe de Acervo e Ateliê de Gravura) e Dona Maria Coussirat Camargo, todos da Fundação Iberê Camargo em Porto Alegre. Devo citar como imprescindíveis a orientação e o constante incentivo do Prof. Dr. Marco Garaude Giannotti. Importantes, também, foram as respostas passadas por Dr. Ella Hendriks, chefe do Departamento de Conservação, e Dr. Hans Luijten, chefe do Projeto Cartas de Van Gogh, do The Stichting Van Gogh Museum de Amsterdã, e por Pauline de La Grandière, restauradora de uma obra de Pierre Soulages, assim como o conhecimento transmitido pelos professores: Prof Dra. Sônia Salzstein, Prof. Dr. Luciano Migliaccio, Prof. Dr. Agnaldo Farias, Prof. Dr. Evandro Carlos Jardim, Prof. Dr. Manoel Lello Belloto, Prof. Dra. Neide Marcondes, ao longo da pós graduação, além das conversas com Caetano Ferrari Célia Euvaldo, José Bernnò, Sérgio Sister, Eurico Lopes, Ricardo Bezerra. Agradeço às minhas irmãs Tereza e Luciana Rangel, pelas revisões do texto e da bibliografia respectivamente, e aos meus pais Tereza e Mário pelo apoio logístico. Não posso deixar de mencionar a paciência dos meus filhos, Marina e Pedro, e de meu marido Eduardo ao longo de todo o processo.

Essa pesquisa foi feita com o apoio de Bolsa da FAPESP. 


\section{Sumário}

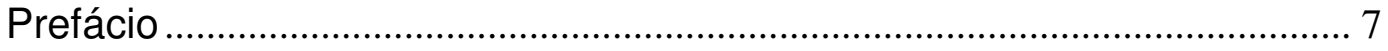

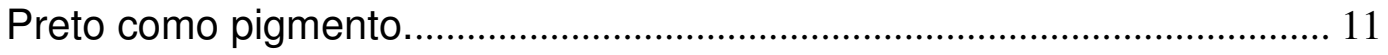

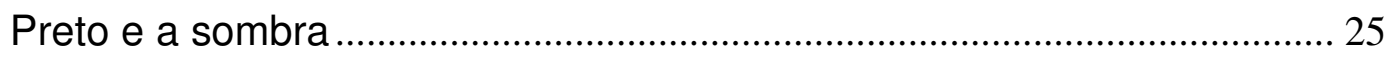

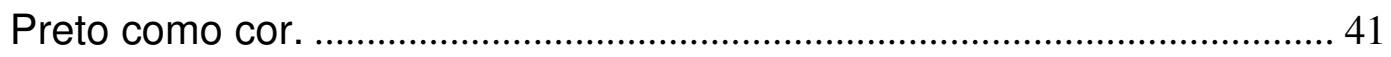

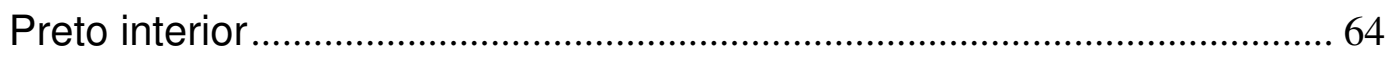

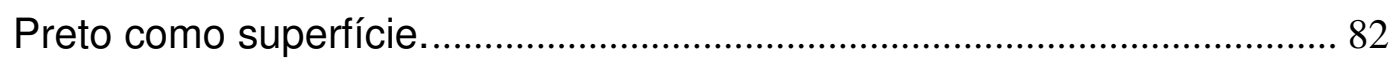

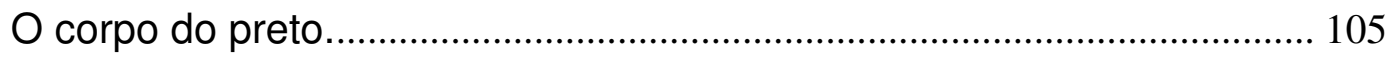

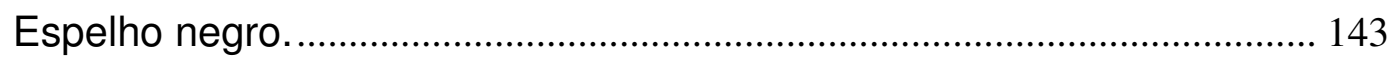

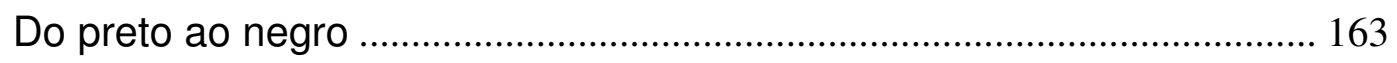

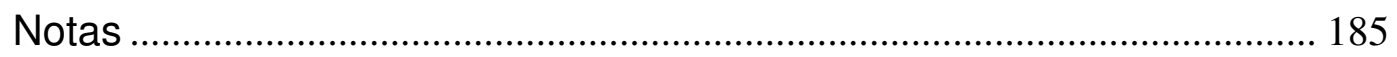

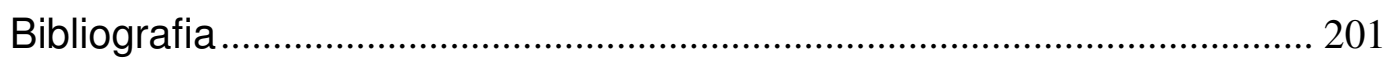

Anexo: Entrevista com Eduardo Sued ....................................................... 206 


\section{Prefácio}

"Quando mantemos os olhos abertos num quarto totalmente escuro, sentimos uma certa ausência. O órgão, retraindo-se, é abandonado a si mesmo."

Goethe

Preto, ao longo da história da arte, foi inicialmente associado à sombra e à escuridão. A partir de meados do século XIX, foi usado como uma cor como outra qualquer. Em alguns casos, em vez de ser um tom que cria o escuro, produz luminosidade. Nesse ensaio, não se pretende abranger todas as manifestações dessa cor, mas apontar para algumas variações de seu uso na pintura. O foco principal do estudo é a análise do modo como seis artistas transformam a tinta preta em campos cromáticos e como essas áreas atuam em seus quadros. Alguns desses pintores fazem figuração, outros abstração. Uns aplicam o preto puro, outros aplicam o preto com várias cores.

Distinguiremos, nesse trabalho, o preto do negro, apesar de serem sinônimos em português. A primeira palavra será usada em obras nas quais o preto funciona como um anteparo, uma barreira que impede o olhar de vagar pelo interior da cor, trabalhando na superfície. Negro será usado nos casos em que se cria uma profundidade, uma espacialidade não contida no plano do quadro. O olhar pode adentrar no campo de cor sem encontrar o fundo.

$\mathrm{Na}$ antigüidade, diferenciava-se a cor preta por seu brilho ou opacidade. Havia dois conceitos. Em latim, duas palavras diferentes, uma para cada caso, eram usadas. ${ }^{2}$ Niger, que nomeava o preto brilhante, originou o substantivo 
negro, em português, e. Ater, que significava o preto opaco, sem brilho, inquietante, deu origem à palavra atrabílis ${ }^{3}$. Nesse estudo, não é o brilho que caracteriza o negro. A cor deve estar em sua máxima saturação e as relações criadas na pintura devem dar a ilusão de profundidade na cor e não pela sobreposição de planos cromáticos ou por construção baseada no desenho. ${ }^{4} \mathrm{O}$ negro é intenso e parece ter luz própria. O preto precisa das relações de contraste com as outras cores do quadro para se tornar luminoso.

Os capítulos Preto como pigmento e Preto e a sombra servem de breve introdução ao uso do preto na pintura. O primeiro trata de questões materiais do plano pictórico - entendido como uma superfície bidimensional, na qual é depositado um pigmento misturado a um aglutinante. Diversos pigmentos pretos que têm sido empregados pelos artistas na pintura ocidental são apresentados. O segundo capítulo traça, em linhas gerais, como o preto foi usado ao longo da história da arte, desde a associação dessa cor às sombras que, pelo contraste com a luz, modelavam os objetos representados na pintura e davam a ilusão de volume, ao uso como cor pelos pintores do século XX.

O capítulo Preto como cor analisa obras de Edouard Manet. O artista transgrediu várias das regras da pintura acadêmica, em meados do século XIX. Deixou de aplicar a perspectiva linear para criar uma ilusão de espaço tridimensional no quadro, reduziu a criação de volume pelo sombreamento, usou cores mais chapadas. Manet iniciou o processo que levou à autonomia do preto enquanto cor.

O capítulo Preto interior aborda o uso do preto por Vincent Van Gogh, não como arrombo expressivo ingênuo, mas como resultado de uma prática 
somada à reflexão, ao estudo de teorias das cores e observação crítica de obras de outros artistas.

Preto como superfície é o capítulo no qual são discutidas algumas pinturas de Henry Matisse, um dos maiores coloristas do início do século XX, em cuja obra reverbera tanto o uso inovador e radical das cores de Van Gogh, quanto o uso do preto por Manet. O pintor não o utilizava como escuridão e sim como uma cor luminosa que, como outra qualquer, cria contrastes com as outras cores dispostas na composição. O preto, nas obras analisadas, não funciona como sombra, indicador de volumetria, mas como elemento que mantém a composição no plano.

O corpo do preto trata de Iberê Camargo, pintor que, apesar de ter "horror ao preto como cor”, no início da década de 1950 passou a utilizá-lo em algumas de suas obras. Seus pretos são um amalgamado de cores numa massa de tinta densa. A alternância entre colocação e raspagem, criação e apagamento, move sua pintura.

Espelho negro descreve tanto obras de Eduardo Sued, nas quais o preto é um campo cromático, quanto aquelas em que a tinta preta brilhante cria áreas que funcionam como espelhos. Na superfície em que se apresenta refletida a imagem do ambiente surge um espaço virtual para além do plano do quadro, o negro.

Do preto ao negro expõe diversas obras de Pierre Soulages. Apresenta sua busca - experimentações com piche, tinta a óleo, acrílica etc. - de uma luz gerada a partir da escuridão. A luz surge do contraste entre o preto e o branco 
ou nas telas que, pintadas com um único pigmento, transformam-se em cor negra que salta para frente do quadro e provoca uma nova espacialidade.

O ensaio não ambiciona estabelecer um conjunto de afinidades nem de oposições entre as produções dos seis protagonistas, não propõe gerar conexões elucidativas e conclusivas sobre a aplicação do preto e do negro. Mas refletir sobre essas ocorrências da cor preta na pintura. 


\section{Preto como pigmento.}

"o material da obra de arte participa da síntese do objeto estético"

Vigotski

Caetano Ferrari, consultor de tecnologia artística, especialista em materiais de pintura, disse que o conhecimento e a experimentação são essenciais para o artista criar e domar seu material ${ }^{7}$. Citou o exemplo do pintor Raoul Dufy que, em 1937, para pintar a obra Fée Electricité composta por 250 painéis de $1,5 \times 2 \mathrm{~m}$, teve ajuda da indústria de tintas artísticas Lefranc \& Bourgeois, e o apoio do, então, diretor industrial Marc Havel, para criação de uma tinta especial para sua pintura ${ }^{8}$.

A experiência técnica, devotada à arte da pintura, levou Havel a escrever, na década de 50, um livro sobre materiais artísticos, ${ }^{9}$ no qual ele defende o domínio técnico como uma ferramenta essencial para possibilitar a transformação da idéia em forma artística. Mas ele cometeu, segundo Caetano Ferrari, ao menos um grande erro: ele previu que os materiais empregados para a pintura a ser feita no final do séc. $X X$ seriam completamente diferentes daqueles de então. Porém, ao longo desse tempo, apesar das inserções de tintas industriais, de elementos oriundos do cotidiano, de agregados matéricos nas obras de arte, muitos pintores ainda lançam mão de algumas das mesmas substâncias usadas para pelos grandes mestres.

O plano pictórico é o local no qual o pintor trabalha para converter a matéria em criação. A superfície bidimensional do suporte é transformada em 
campos de cor que se comportam de maneiras diferentes dependendo da base, da técnica empregada, da tinta, do modo de aplicação dessa tinta e da luz incidente nessa superfície. De uma maneira geral, uma pintura é composta por uma estrutura formada pela sobreposição de camadas de substâncias com naturezas químicas e físicas diferentes. A face visível da pintura, na qual surgem as formas e as cores, é constituída pelas camadas mais superficiais, que podem ou não ser o verniz, mas certamente possui a tinta. Essas camadas serão deitadas sobre uma base preparada sobre o suporte, que pode ser tela, madeira, metal ou outro material.

Todos os extratos são importantes para a aparência final da pintura, mas nos deteremos, aqui, na tinta. Ela é composta por três elementos principais: o pigmento, o aglutinante ou excipiente e a carga. Os pigmentos, responsáveis pela cor, são substâncias que se conservam como partículas discretas, quando moídos para ficar numa suspensão, no meio de um aglutinante. Possuem propriedades óticas singulares, além de terem características físicas únicas. Há aqueles com arestas e irregularidades, outros, porém, poder ser suaves e arredondados. Alguns absorvem muito óleo durante a moagem e, por conseqüência, demoram mais a secar que aqueles que absorvem apenas uma pequena quantidade. Essas diferenças fazem com que cada pigmento requeira procedimentos específicos durante o processo de trituração. Como veremos mais adiante, há diversos pigmentos para obtermos a cor preta, cada qual terá suas peculiaridades e servirá de maneira específica ao artista.

O excipiente para a cor, ou aglutinante, serve em primeiro lugar para transportar e cobrir o pigmento. Isto é, para a obtenção da cor, o pigmento deve estar devidamente envolvido pelo aglutinante. Ou seja, o meio deve estar 
livre de impurezas e o pigmento uniformemente dispersado e suspenso para permitir que o pintor trabalhe a cor, de modo consistente pela superfície. Em segundo lugar, será o responsável pela aderência da cor à superfície. Isso ocorre pela formação duma película uniforme e estável. Por exemplo, na técnica da têmpera pode-se usar como aglutinante uma emulsão de água e gemas de ovo, ou ovos inteiros, ou cola ou caseína. Na encáustica usa-se cera. Na pintura a óleo, podemos encontrar o óleo de linhaça.

Algumas vezes uma carga ou um aditivo deve ser incluído para alterar determinada característica da mistura entre o aglutinante e o pigmento. Esse pode ter a função de alterar a viscosidade da tinta, melhorar o tempo de secagem, dar transparência etc.

Desde a distante pré-história, tem-se triturado, moído, misturado e aplicado pigmentos em superfícies, para criar pinturas e desenhos. As primeiras pinturas das quais temos notícia foram feitas nas paredes ásperas de cavernas. Antes das civilizações começarem a ensaiar seus primeiros passos, alguém penetrou numa caverna escura e criou as primeiras pinturas figurativas, ele utilizou uma paleta baseada em vermelho, amarelo, branco e preto. As imagens incluem cenas com animais, esboços antropomórficos, mãos contornadas em negativo. De uma maneira geral, as análises efetuadas em diversos sítios ao redor do mundo revelaram que os pigmentos pretos utilizados eram constituídos basicamente por pastas à base de carvão vegetal ou animal e, em alguns casos à base de óxido de manganês. O pigmento, além de ficar mecanicamente preso na pedra porosa, aderia à superfície, pois, o aglutinante - que podia ser barro, saliva, óleos vegetais e até mesmo sangue - secava e o fixava. 
Nossos antepassados remotos produziam seus pigmentos pretos e os misturavam a pigmentos brancos para criar tons de cinzas. Por exemplo, na Caverna de Chauvet, França, há várias figuras pretas, criadas, principalmente, pela aplicação de matéria vegetal carbonizada. Estudiosos concluíram que, além da clara função de ser fonte de luz, diversas fogueiras foram acesas com o objetivo de gerar quantidade suficiente de carvão, para ser usado como pigmento. Nessa caverna há várias figuras cuja ilusão de volume foi criada pelo uso de variações de tons de cinza, obtidos pela adição de argila ao carvão. ${ }^{10}$

Assim como nos sítios arqueológicos do Piauí, Brasil, cujas imagens apresentam representações antropomórficas. São cenas de caça, danças, rituais, sexo etc. Os pigmentos pretos aplicados, por exemplo, na Serra da Capivara, foram elaborados a partir de ossos animais queimados e triturados, além do carvão vegetal. O ligante utilizado foi água da própria região, enriquecida com cálcio. Há figuras, inicialmente pintadas com carvão vegetal, que após serem recobertas por um depósito silificado, tornaram-se azuladas. Já o cinza foi obtido pela mistura de um vermelho (hematita) com um branco (calcita).

Os homens pré-históricos possuíam certa prática na obtenção dos carvões para utilizá-los em suas pinturas, mas conseguiam também criar seus pretos com outros produtos naturais. Por exemplo, em Lascaux, empregaram além de óxido de ferro, compostos de óxido de manganês.

No berço da civilização Egípcia, cerca de 3000 anos antes da era cristã, às margens do Nilo e em seu Delta, os egípcios já usavam a cor como complemento decorativo. Ao longo de sua civilização, que durou três milênios, eles foram hábeis coloristas. A pintura egípcia antiga pode ser dividida em duas 
categorias: aquelas criadas com fins religiosos, associadas a práticas de cura ou rituais funerários, e aquelas usadas com propósitos decorativos. Nas primeiras, a paleta estava limitada a seis cores: branco, amarelo, vermelho, azul, verde e preto, que eram aplicadas respeitando seu caráter simbólico. Nesse caso, as cores deviam ser justapostas, jamais misturadas sob pena de perder seu significado. Afinal, as cores revelavam pistas sobre a natureza dos seres que estavam sendo pintados. Para os antigos egípcios, preto (cujo nome arcaico era kem) estava associado à morte, às profundezas e à noite, mas também à ressurreição e à fertilidade. Os dois últimos aspectos relacionam-se às inundações anuais do Nilo, cujo lodo negro transbordante escurecia e fertilizava o solo, e deu origem ao nome pelo qual o país era conhecido na antigüidade: "Terra preta" (kernet). Branco era a cor da pureza, das coisas sagradas e simples. Verde representava nova vida, crescimento, e assim como o preto, fertilidade. Vermelho, a cor do caos e da desordem, a cor do deserto infértil, era o par oposto ao preto. Amarelo simbolizava aquilo que era eterno e indestrutível como o sol e o ouro. Azul estava tanto para os céus quanto para as águas.

Quando a obra tinha uma finalidade estritamente decorativa, o pintor podia usar outras cores, como rosas, violetas, marrons etc. Essas podiam ser obtidas pela utilização de outros pigmentos ou por mistura ou sobreposição das seis relacionadas anteriormente. Quando pintavam coisas laicas que se sobrepunham, eles lançavam mão de cores variadas, para diferenciar os objetos.

Os egípcios inovaram nos materiais sobre os quais pintaram. Decoraram estatuetas de pedras, caixas de alabastro, sarcófagos feitos de madeira, 
papiro. Cada qual exigia técnicas específicas de preparação do suporte. Por exemplo, a base das pinturas em alguns sarcófagos era uma pasta de gesso ${ }^{11}$. A utilização de aglutinantes apropriados no preparo das tintas, que garantissem a durabilidade da obra, também mereceu atenção especial. Os pigmentos, finamente moídos e triturados, eram, em muitos casos, misturados a uma cola de origem vegetal.

Para obter a cor preta, os egípcios utilizavam os mesmos pigmentos que se utilizam atualmente, ou seja, madeira carbonizada (carvão vegetal), ossos calcinados (carvão animal), fuligem que emanava de lampiões a óleo e, mais raramente dióxido de manganês. Os vermelhos e amarelos, mais comumente usados, eram oriundos dos ocres, terras abundantes no deserto, naturais ou queimados. Para o vermelho, usava-se também óxido de ferro natural, além de um sulfeto de arsênio, conhecido por realgar ${ }^{12}$. Um amarelo-real ${ }^{13}$, obtido com o emprego de sulfito de arsênio, e um amarelo ácido pálido feito com jarosita ${ }^{14}$ também faziam parte das pinturas.

Além das obras, nas quais foram feitas as análises para determinar a composição dos elementos que compunham as pinturas, o conhecimento que se tem sobre algumas das técnicas empregadas pelos antigos é oriundo de dois conjuntos de papiros. Os Papiros $X$, da coleção Leiden, que contém detalhes sobre pigmentos e ligas metálicas. E os Papiros de Estocolmo que enfatizam a arte de tingir tecidos, seus corantes e mordentes, e a imitação de pedras preciosas.

A pintura era importante também na Grécia antiga, apesar de serem raríssimos os exemplares de pintura mural ou de painéis que chegaram nos dias atuais ${ }^{15}$. Muito da informação que temos deriva de escritos sobre a época. 
Sabe-se que usavam o afresco, a encáustica e a tempera. Podemos considerar - livro XXXV, do tratado de História Natural do escritor, historiador, administrador e oficial romano Plínio, o Velho, uma das principais fontes sobre as técnicas e materiais usados pelos pintores da antigüidade. Outras fontes importantes são Marco Vitruvio Pollone, autor do tratado De Architectura e Teofrasto de Lesbo, discípulo de Platão e Aristóteles, a quem se atribui $D e$ coloribus (Sobre as Cores).

Plínio, o Velho, afirmou que a grande pintura antiga, aquela feita por Apeles, Polignoto, Nicomaco e Zeuxis, usava uma paleta econômica. Era uma paleta de quatro cores: melinum para o branco, Attic sil para o amarelo, Pontic sinopis para o vermelho e atramentum para o preto. ${ }^{16}$

O preto presente nessas pinturas era oriundo de pigmentos obtidos principalmente por combustão. Apeles (séc. IV a.C) descobrira o negro-demarfim, obtido da calcinação de presas de elefantes (elephantinum, Plínio, xxxv 42). Polignoto ( 475 e 447 a.C) e Mícon (V. séc a.C) produziam seu pigmento da queima do mosto. Usava-se também a fuligem obtida da queima de uma resina (nosso negro de fumo), ou galhos de videira incinerados (preto de vinha). Plínio menciona um pigmento preto natural não identificado, que poderia ser turfa, um óxido de ferro ou um óxido de magnésio. Entretanto, o melhor preto chamava-se atramentum Indl.um, provavelmente Nanquim (negro de fumo chinês) que chegou no ocidente através da Índia. ${ }^{17} \mathrm{O}$ texto de Plínio cita uma variedade de pigmentos, o que faz supor que a qualidade cromática do pretos variasse de acordo com o componente utilizado. Além da cerâmica, quase nada restou da pintura grega. Mas há algumas evidências que apontam para possibilidades de paletas. Sabe-se, por exemplo, que pintores antigos no 
séc.III. AC usavam, entre outras cores, três pigmentos pretos para pintar as lápides em Volos, na Grécia.

Algumas informações sobre os pigmentos e corantes usados na Idade Média derivam de diversos tratados técnicos e artísticos escritos entre o primeiro e o décimo quinto século. Dentre os quais podemos citar: De diversis artibus, escrito pelo abade alemão Teofilo (XII século d.C.) e o "livro de arte", de Cenino Cennini (1390). Os pigmentos mais comuns utilizados na Idade Média podem ser agrupados em quatro categorias: terras, minerais, pigmentos fabricados e orgânicos. As cores principais eram azuis feitos de azurite ou lápis lázuli, verdes de cobre e terra, amarelo de ocre e de arsenico, vermelho de ocre e de vermelhão ${ }^{18}$, pretos de terra e de carvão de origem animal ou vegetal. Muitas das pesquisas sobre química e tecnologia de pigmentos eram feitas por alquimistas, cujas técnicas e descobertas eram escritas numa linguagem repleta de metáforas e simbologias, para se manterem secretas. $\mathrm{Na}$ Idade Média o preto de lâmpada era feito ao deixar que a fumaça da chama de uma vela de cera de abelha, ou de uma lamparina com óleo de linhaça, ou de oliva, ou com um insenso incandescente, depositasse numa superfície fria. A qualidade do pigmento variava de acordo com o material usado na combustão.

A descoberta de novos pigmentos fez com que a paleta usada no século $\mathrm{XV}$ fosse muito mais rica que as dos séculos precedentes. A pintura, com a introdução da perspectiva atmosférica, passou a requerer uma maior experimentação de cores. Os artistas da Renascença manipulavam-nas para criar ilusões de volume. Há várias fontes bibliográficas, dentre as quais podemos citar "Da pittura" (c1435) de Leon Alberti, "Tratado da pintura" (1492) de Leonardo da Vinci. Apesar da introdução de novos pigmentos, os pretos 
continuavam a ser produzidos com os mesmos métodos e materiais utilizados desde a antigüidade. Pretos feitos à base de carvão mineral ou animal e pretos minerais.

Vale a pena apontar que o conhecimento sobre os pigmentos e materiais pictóricos era muito importante para os artistas. Um jovem que desejasse tornar-se pintor, na Itália renascentista, passava por um ritual de aprendizagem. Após ser aprovado por um mestre já estabelecido e reconhecido, num processo de avaliação que durava um ano, o jovem passaria doze anos sob a tutela desse mentor. Durante os seis primeiros anos, sob um juramento de não divulgar os segredos, ele exercitaria as funções de triturar, misturar os pigmentos, preparar tintas e o suporte, e outras tarefas mecânicas relacionadas à arte da pintura. Nos seis últimos anos, aprenderia a pintar. ${ }^{19}$

Os italianos, assim como os flamengos, holandeses e franceses dedicavam um cuidado especial na escolha, purificação e preparo dos pigmentos. A qualidade era muito importante. Os mestres preocupavam-se, entre outras coisas, com as capacidades secantes do pó, e pesquisavam maneiras para controlar essa característica. Os pretos, por exemplo, possuem secagem muito lenta. Além disso, requerem maior esforço no seu preparo, pois, como embolotam, devem ser moídos com mais força e por mais tempo que outras cores. Cennino Cennini dedica um parágrafo de seu tratado para o preparo do pigmento preto, no qual ele afirma que o pintor deve pegar algum preto do tamanho de uma noz, colocá-lo no pórfiro e quebrá-lo em pedaços pequenos. Feito isso, deve adicionar um pouco de água limpa, e triturar o pigmento por tanto tempo quanto for possível, mas deve-se ter em mente que, se formos triturá-lo "por um ano, mais negra e melhor será a cor". ${ }^{20}$ 
Os textos antigos apresentam diferenças entre os materiais. Relatam que um mesmo pigmento preto não podia ser aplicado em todas as situações que necessitassem dessa cor, seja a aplicação em uma superfície uniforme, seja misturá-lo a outras cores para escurecê-las. O que ocorre, na realidade, é que uma substância pode produzir um efeito ótimo se aplicada em uma pequena superfície, mas parecer sem vida, se a área pintada for grande. Por isso, havia uma diferenciação dos pigmentos pretos utilizados, cujos nomes remetiam ao material que Ihe dava origem. É interessante observar como, em diversos textos antigos, escreve-se sobre as diferenças da cor preta obtida mediante a utilização de determinado material. Alguns dos pigmentos, relacionados desde os primórdios da arte pictórica, continuam a ser utilizados nos dias de hoje.

Entre as várias substâncias à base de carbono, temos:

Negro de fumo ou de lâmpada produzido a partir da fuligem, aquela fumaça espessa, exalada de corpos resinosos em estado de combustão. Muitos autores recriminam sua utilização em obras de arte, pois é um preto avermelhado, muito difícil de molhar, com uma secagem muito lenta, e não tão permanente. Recomendam-no para aplicações artesanais. Mas é um pigmento que desde a antigüidade tem sido aplicado em pintura artística, desde que tratado com cuidado. Nesse caso, para obter um melhor resultado, ele era lavado, para separar as impurezas, e reduzido ao estado de carvão puro. ${ }^{21}$

Com relação ao preto obtido com carvão de origem animal, vários autores distinguem o negro de marfim do negro de osso, pois o primeiro é intenso e transparente, e se for bem preparado jamais desbota. O segundo é obtido pela calcinação de ossos de vários animais. Havia quem preferisse ossos de porco e carneiro, outros citam cornos de cervos. Mas o preto obtido é um pouco 
avermelhado e se, a calcinação for interrompida antes do tempo devido, pode tornar-se um pigmento marrom.

Há vários pretos feitos com carvão vegetal. Dependendo da origem podem ser um pouco menos intensos que o de marfim. Um dos melhores pretos é obtido pela incineração de galhos novos de videira, conhecido também, por preto-azul. Criava-se, também, um preto pela queima do mosto de vinho, o produto já em fermentação cujo tanino é lavado antes da combustão. Em alguns textos esse pigmento é nomeado preto de Frankfurt, apesar de ser produzido também na França. Havia um pigmento obtido pela queima de caroço de pêssego que, ao ser misturado com branco, dava um tom azulado. Queimavam também nozes, amêndoas, cortiça, pinho, café, sementes de cereja, de uva etc.

Existem também pretos de origem mineral. Os italianos retiravam terra nera, um pigmento natural untuoso, de diversos lugares, entre eles Piemonte, Roma, Veneza e Verona. Já a terra nera di Campana era feita de uma crosta que se formava nos moldes usados para a fundição de sinos e armas, foi usada num pequeno período, pois desbotava e estragava as pinturas. Nero di schiuma di ferro era obtido da mistura de ferro com terra verde moída finamente. Havia o negro da Prússia ou da Rússia, um ocre preto. Além disso, podem-se obter pretos compostos, por exemplo, com uma mistura de um azul escuro com um siena queimado.

O azul da Prússia que foi inventado em 1704 é um dos marcos na história dos materiais da pintura. Aponta para o início da produção de pigmentos sintéticos e as futuras alterações nas paletas empregadas. No século XVIII, foram descobertos vários elementos como, por exemplo, o cobalto e o 
tungstênio. A produção industrial de pigmentos começou e, até meados do século XIX, uma gama variada de cores surgiu. Equivalentes sintéticos das antigas terras negras, preto de marte, um óxido de ferro, e o preto de manganês foram comercializados. Além disso, azul de cobalto, azul e violeta ultramar, branco de zinco, vermelho de cromo etc. passaram a estar disponíveis. Dessa forma, as possibilidades de pretos compostos aumentaram.

Ainda no século XIX, a tinta à óleo, cuja utilização remonta ao século XV, foi industrializada e, em vez de comercializada em bexigas de porco, passou a ser vendida em tubos metálicos. Os artistas podiam carregar com facilidade suas tintas para pintar ao ar livre. Apesar de não terem de preparar suas tintas, os artistas dividiam uma preocupação quanto à tendência do óleo, em certas cores, acumular na superfície e formar uma película que amarelaria devido à oxidação. Van Gogh deixou instruções para que uma tela fosse lavada várias vezes com água fria e recebesse depois uma camada forte de verniz quando a massa estivesse totalmente seca, para que os pretos não tivessem uma aparência suja quando o óleo migrasse para a superfície ${ }^{22}$. Em várias fontes bibliográficas do século XIX encontram-se recomendações para se lavar ou desengordurar a superfície de uma camada de pintura, antes da aplicação da camada posterior ou do verniz. ${ }^{23}$.

A partir do século $X X$, a implantação das inovações dos materiais artísticos foi mais lenta. Houve, a introdução de alguns novos pigmentos na tecnologia de pintura automobilística, imobiliária, eletrônica etc. Mas, por questões mercadológicas, demoram muito a serem adotados pela indústria de produtos para a fatura de arte. $\mathrm{O}$ advento da tinta acrílica, ocorrido na década de 1950, foi a única mudança dramática ocorrida no século XX. 
Muitos dos pigmentos pretos utilizados pelos artistas de hoje são os mesmos usados desde a antigüidade. Um dos produtos mais comumente encontrado é o negro de osso, muitas vezes chamado de negro de marfim, ele é constituído por partículas grosseiras e irregulares, algumas delas são transparentes e outras um pouco avermelhadas. Alguns fabricantes oferecem também o preto de carbono, chamado preto de lâmpada.. Encontram-se também equivalentes sintéticos, desenvolvidos em meados do século XIX, das antigas terras negras: o preto de marte, óxido de ferro sintético, e o preto de manganês. Podem ser encontrados, mais raramente, preto de vinha e de cereja, negro de marfim autêntico. ${ }^{24}$ Há quem ofereça um preto composto, criado pela mistura de cores complementares. ${ }^{25}$ Dos produtos disponíveis atualmente, há duas novidades que migraram da indústria aplicada para a de materiais artísticos o negro spinel e o perylene. O primeiro é um preto sintético composto por uma estrutura cristalina de cobre, manganês e ferro, cujo preço equivale aos dos amarelos de cadmium. E o preto perylene, um novo pigmento orgânico, sintetizado a partir das fórmulas oriundas das substâncias que fazem com que pelos dobs animais sejam negros.

A afirmação da necessidade de revermos as questões técnicas que envolvem a pintura pode parecer uma ode a um formalismo estrito. Porém, se considerarmos que forma, matéria e conteúdo estão engastados, que a escolha de determinada técnica em detrimento de outra, por si só, já está carregada de significado, veremos que, apesar de ter sido desprezado nos últimos anos, o conhecimento técnico pode ser muito útil ao artista. Um pintor sem o domínio técnico, diferentemente de um poeta analfabeto, cujos poemas não passariam de idéias, não será impedido de pintar, porém talvez restrinja sua obra. 


\section{Preto e a sombra}

As cores são ações e paixões da luz. Nesse sentido, podemos esperar delas alguma indicação sobre a luz. Na verdade, luz e cores se relacionam perfeitamente, embora devamos pensá-las como pertencentes à natureza em seu todo: é ela inteira que quer se revelar no sentido da visão.

Goethe $^{26}$

A sombra está associada ao mito da origem da representação artística. Segundo Plínio, o velho, apesar das disputas e incertezas a respeito do nascimento da pintura, todos concordavam que sua gênese fora o contorno de uma sombra humana projetada numa parede. Segundo o romano, a pintura evoluiu para representações monocromáticas nas quais o contorno era preenchido. Exemplos dessas pinturas monocromáticas não chegaram aos nossos tempos, mas podemos fazer uma analogia com as decorações de vasos e ânforas nas quais, freqüentemente, temos a figura humana, muitas vezes representada de perfil, preenchida por preto ou vermelho. Quando alcançou sua fase mais desenvolvida, a pintura passou a ser feita com efeitos de variações de luminosidade, pelo uso de contrastes e harmonizações de cores. Existem raros exemplos gregos, mas tanto as pinturas murais de Pompéia (fig.a) quanto os mosaicos romanos antigos dão pistas sobre como era a representação pictórica de então. O preto podia ser pintado como fundo ou como os sombreados, no modelado dos corpos, ou nas sombras projetadas. $^{27}$ 
Se de um lado os pintores usavam as cores, de outro os pensadores tentavam decifrar o fenômeno cromático. Aristóteles cunhou uma hipótese que foi utilizada até o século XVII, por Goethe. Afirmou que as cores surgiam quando diferentes proporções de luz e ausência de luz ou sombra (Skieron) incidiam sobre os objetos. Portanto, as cores surgiam da mistura da escuridão com a luz.

Durante a Idade Média, a luz foi revestida de um caráter metafísico. Os pintores suprimiram as sombras projetadas e reduziram a modelagem dos corpos, pois as obras não visavam a espelhar a realidade, mas a transmitir a idéia do sagrado. Adotou-se um método mais simplificado de representação, que permitiu maior liberdade na composição, pois as formas não deviam ser subordinadas ao mundo visível externo, podiam ser organizadas hierarquicamente, conforme a importância dentro do quadro. Apresentavam seres incorpóreos, leves e transparentes, que não possuíam carne nem projetavam sombras. Como o espaço criado na pintura medieval era um espaço simbólico, o preto era geralmente associado a uma carga negativa, às trevas, à morte, ao inferno e ao mundo subterrâneo. Em meio às cores vibrantes usadas pelos pintores e ilustradores da Idade Média, alguém vestido de preto estaria representando o isolamento da vergonha (fig.b), por exemplo.

Na Renascença, a pintura passou a espelhar o mundo do ponto de vista do homem. Buscaram-se artifícios para que a imagem na tela fosse semelhante à que era enxergada por uma visão monocular, e fixa. Brunelleschi formulou as regras da perspectiva linear, um método que, pautado na geometria, cria um espaço virtual da tela a partir do desenho. 
Alberti em seu tratado Da pittura, além de relatar os procedimentos de Brunelleschi para se construir a pirâmide visual da perspectiva linear, separou o conceito de luminosidade do de matiz e explicou como criar a ilusão de volume na superfície do quadro:

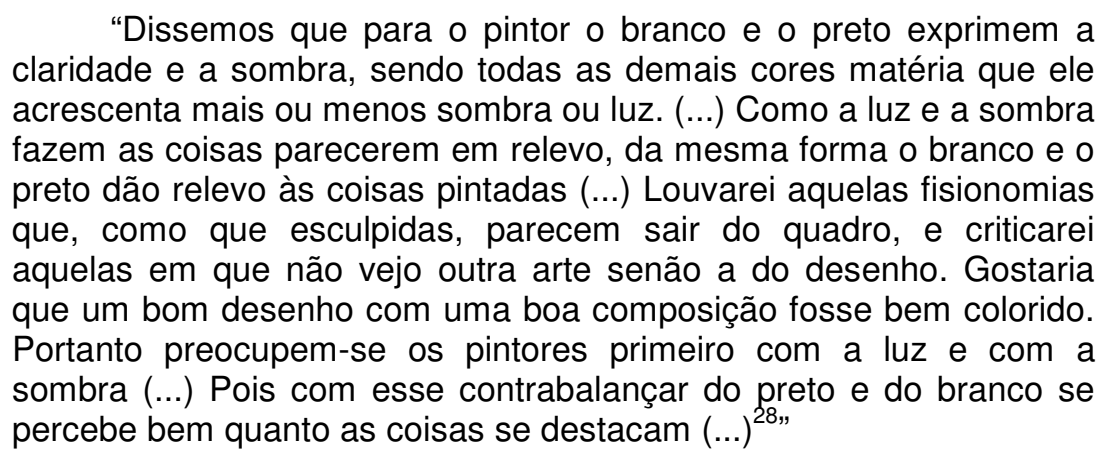

Dessa forma Alberti enunciou os princípios que vigoravam na pintura renascentista, ou seja, criar um espaço virtual baseado num bom desenho perspectivo e com escorço, para posteriormente ser colorido com boa gradação de luz e escuridão, ou seja, chiaroscuro. A cor fica dessa forma subordinada ao desenho. ${ }^{29}$

Ao final do Renascimento a rigidez da perspectiva linear foi substituída por outras formas de criação de espaço no quadro. O ponto de vista único coincidente com o ponto de fuga foi trocado por pontos de vistas múltiplos. Leonardo Da Vinci que aplicava o esfumato (sfumato), na qual os contornos das figuras eram diluídos, e uma área colorida mesclava-se com a outra, utilizava um chiaroscuro mais esfumaçado como uma das principais ferramentas para a modelagem das formas. ${ }^{30}$.

Da Vinci redigiu um tratado pautado na observação das cores na natureza. Escreveu detalhadamente sobre o comportamento das sombras, inclusive sobre o fenômeno das sombras coloridas, da interferência mútua 
entre as cores dos corpos. Além disso, formulou a perspectiva aérea, na qual os objetos mais distantes têm sua cor natural corrompida e tornam-se mais azulados. Ou seja, a profundidade virtual podia ser criada pela variação das cores e não somente pela linha (fig.c). Com isso, a antiga disputa entre a primazia do desenho (disegno), atribuída aos pintores de Florença, e a cor (colore) da pintura veneziana começou a enfraquecer.

A modulação pelo contraste entre a luz e sombra foi ampliado pelo tenebrismo, um estilo de pintura que, pautado na escuridão, surgiu em Roma. no início do século XVII. Caravaggio foi o seu maior expoente. O artista usava a luz e as sombras arbitrariamente, não somente para realçar os volumes, mas também para dar forma às trevas (fig.d). Reduziu a quantidade dos objetos retratados. Concentrava-se nas cores sombrias, nos contrastes, focos de luz realçados pela escuridão circundante, e na atmosfera da cena. $O$ uso desse claro-escuro, a simplificação da composição e a remoção dos supérfluos alterou a espacialidade do quadro. Antes as composições eram mais complexas. Para haver a ilusão da profundidade, pintavam-se vários planos paralelos, que pareciam sobrepostos. O olhar pulava de plano para plano para entender a pintura. Caravaggio criou um bloco único, muito semelhante ao enquadramento fotográfico. A cena era recordada a partir de um ponto de vista mais individual, subjetivo, restringia-se ao essencial. Um dado peculiar é que Caravaggio usava um fundo sempre raso, muito escuro, por vezes potencialmente preto. Se, por um lado, a drástica redução da paleta foi adotada por pintores dos países do norte como Rembrandt (fig. f), e alguns espanhóis, entre eles Goya (fig. g), nos séculos seguintes, por outro, sempre houve os que 
preferiam uma paleta luminosa, nas quais o preto era usado com muita parcimônia.

Vale a pena lembrar que para fazer o sombreado na pintura, o preto era misturado às outras cores, usado para alterar-Ihes a luminosidade. Se por um lado, o preto puro foi praticamente eliminado nas representações da paisagem, por outro, começou a aparecer nas vestimentas dos retratos. O preto era do luto, mas também estava associado com uma cor moral, podia significar justiça nos juízes, humildade nos nobres, penitência nos pecadores, honestidade nos mercadores. A Reforma declarara guerra aos tons claros e vivos e professara uma ética de austeridade e de sobriedade. Os grandes reformistas foram retratados vestindo preto. Mas o preto foi uma cor que vinha sendo usada, não somente por eclesiásticos mas também por reis e comerciantes ${ }^{31}$.Por isso os pintores como Ticiano, Franz Hals (fig.e) e Velásquez (fig.h) tiveram de desenvolver um olhar sutil e uma técnica refinada para retratar variações das nuances pretas nas vestes, chapéus e mantos.

Goethe, segundo quem, no início do século XIX, os homens cultivados tinham "aversão às cores"32 nas roupas e se vestiam de preto, contribuiu com o entendimento da visão colorida. Escreveu a Doutrina das $\operatorname{cores}^{33}$, na qual analisou o fenômeno cromático a partir de sua manifestação na retina. Ele discordava da concepção física, segundo qual a luz branca se decompõe no espectro cromático. Para Goethe, a luz era indivisível ${ }^{34}$. Em seu entendimento, o fenômeno primordial da cor ocorria quando se enxergava a mistura entre a luz e a sombra (Skieron). Escreveu: 
desenvolvem a partir desses opostos com a ajuda de sua mediação, como que num antagonismo, cuja alternância remete imediatamente a algo comum. ${ }^{35}$

Nesse caso, a cor não é uma prerrogativa dos objetos, mas sim daquilo que "vemos", ou seja, é a retina que exerce atividade fundamental na produção das cores. O mundo colorido existe a partir de um olho vivo e ativo. Desse modo, as cores alteram a percepção espacial "um objeto escuro parece menor que um claro do mesmo tamanho" ${ }^{\text {"36 }}$. Goethe também tratou de cores que, mesmo não presentes no mundo exterior, eram criadas no olho. Citou as misturas aparentes, devido às quais, por exemplo, "listras amarelas e azuis, a distância, produzem uma superfície verde" ${ }^{, 37}$. Além de ter mencionado os pares de cores complementares, ${ }^{38}$ escreveu também que na perspectiva aérea os objetos mais distantes, não só parecerem mais desbotados mas ficavam menos nítidos que aqueles mais próximos. ${ }^{39}$ Todos esses conceitos coincidem com processos que alteraram a espacialidade pictórica para um ambiente criado pelas cores. A tela deixou de ser uma janela transparente para o mundo, vista a partir de um olho ideal, na qual aparecia com igual nitidez tanto os objetos próximos quanto os distantes.

Se a tela pode revelar a percepção do artista, os objetos podem ser apresentados com graus diferentes de nitidez dependendo, não somente da distância, mas também do centro focal. Isso é, ao se focalizar um ponto, o restante da cena, a visão periférica, parece desfocado ${ }^{40}$. Por isso, na tela $O$ balcão (1868-1869) de Manet, cujo foco central é a mão da moça que segura o leque, todo o restante torna-se mais desfocado conforme as áreas ficam mais distantes desse ponto. Portanto, no rosto da outra moça, não se distingue 0 nariz, e menos nítido ainda é o rosto do homem. O branco e o preto nessa tela 
não foram usados para modelar as formas, mas, para criar planos cromáticos que se afastam ou aproximam pela cor. $\mathrm{O}$ branco traz para frente as figuras femininas, e o vestido mais alvo parece mais próximo que o que é um pouco azulado. Já o preto, afasta a figura masculina. Manet, em meados de 1860, abandonou a perspectiva linear e eliminou de sua pintura a criação o modelado pelo chiaroscuro, pelas as gradações de cinza. Intensificou o contraste entre áreas de cor. As cores apareciam como planos cromáticos mais intensos, dessa forma, preto era usado como uma cor, e não mais sombra.

Os impressionistas, paralelamente, ao buscarem fixar a percepção visual de um instante, fizeram pinturas compostas de áreas coloridas cujas fronteiras foram embaçadas, nas quais o preto praticamente não era usado. Signac e Seurat criaram um método que funcionava pela mistura aparente das cores prismáticas, ou seja, a cor percebida seria a sintetizada na retina a partir daquelas distribuídas na superfície do quadro, por pequenas pinceladas. O que ocorria nesse último caso é que as cores, em vez de se realçarem, neutralizavam-se, e os matizes prismáticos, que tinham saído dos tubos em tons intensos e vibrantes, eram percebidos no quadro como tonalidades atenuadas, quase cinzas. Cézanne, para que sua pintura não sucumbisse à planaridade física da tela, na tentativa de restituir a volumetria ilusória, fragmentou os objetos em pequenos planos com contrastes de cores frias e quentes, que de certa forma funcionavam como um sombreado cromático. A imagem era formada por percepções sucessivas desses fragmentos.

Van Gogh, para que as cores mantivessem a intensidade e o brilho que tinham ao sair do tubo, evitando a neutralização do método pontilhista, além de servirem para expressar com violência suas idéias, após refletir sobre teorias 
das cores e obras de outros artistas, passou a usar as cores mais arbitrariamente, isso é, sem mimetizarem a cor do modelo, e em grandes planos que se realçavam mutuamente. A relação entre as cores, e não mais o tema retratado, devia produzir as emoções.

Matisse, no início do século $X X$, aplicou as cores com grande arbitrariedade, usou-as para criar tensão na superfície e simultaneamente estruturar os espaços. Empregou o preto como uma cor qualquer. Matisse construiu as formas pela interação entre cores avizinhadas, cada qual com um valor próprio dentro do quadro, não mais subordinadas ao tema ou a forma. Pois, as cores não foram mais escolhidas em função da forma, mas a forma construída a partir da cor. A interação entre as cores ativava o espaço da tela, cuja superfície, que já não era análogo à janela renascentista, deixou de ser equivalente à retina impressionista.

Picasso e Braque preocupados na criação de uma ilusão escultórica usando meios pictóricos, em encontrar equivalentes planares aos aspectos volumétricos, criaram o cubismo. Sistema que em sua primeira fase dispunha de uma paleta reduzida e visava a decompor o objeto em pequenos fragmentos de planos sombreados que se interceptavam e criavam arestas de cubos virtuais (fig. i). A dissecação das figuras em pequenos planos era feita mesmo ao preço de sacrificar a verossimilhança. Por isso o preto, ao ser aplicado com gradações de cinza, surgia como sombreado e restituía a ilusão de relevo aos pequenos planos facetados. Mesmo separado das formas do modelo, mesmo altamente fragmentado, as variações de luminosidade tinham uma capacidade de vincar os pequenos planos, dando-Ihes profundidade. Após a introdução da colagem, os pequenos segmentos de cubo foram sobrepostos aos campos 
formados pelo material colado, e foram sintetizados em áreas maiores e planas de cor para manter a integridade da superfície do quadro (fig.j). O sombreado era usado incisivamente e dava um efeito geral de baixo relevo. Mas, justamente por serem tão contundentes, essas grandes áreas escuras passaram a existir por si só, apartaram-se do modelo, passaram a não ter uma função de iludir volume e acabaram por se tornar "formas independentes constituídas por pretura e acinzentado puros". Essa transformação, além de contribuir para a ambigüidade entre o plano do quadro e a ilusão de volume dessas colagens, "serviu para reduzir o sombreamento a um mero componente do desenho da superfície e do esquema de cromático". Ele perdeu sua capacidade de modelagem e virou uma forma per-se. "Quando o sombreado torna-se isso, todas as outras cores tornam-se cores mais puras." Por isso a paleta de Picasso e Braque abandonou a tendência monocromática para incluir matizes mais vivos, por volta de $1913 .{ }^{41}$

Juan Gris fez uma série de pinturas, entre 1915 e 1918, nas quais as sombras passaram a ocupar o lugar das formas (fig.k), e como escreveu Greenberg:

"As formas pretas sólidas simples e assepticamente contornadas, nas quais Gris confiou tanto, nessas pinturas representam sombras fossilizadas e padrões fossilizados de sombreamento. Todas as gradações de valores estão sumarizadas em um único e essencial tom preto plano opaco - um preto que se torna uma cor tão sonora e pura quanto qualquer outra cor do espectro e confere às silhuetas seu enchimento e um peso muito maior que as formas de tonalidades claras que essas silhuetas deveriam sombrear" ${ }^{\text {,42 }}$ 
De Chirico inverteu a utilização das sombras, pautou-se nas regras da perspectiva linear para esgarçar a profundidade virtual construída matematicamente. Em seu emblemático Melancolia e Mistério (1914) (fig.I), criou uma separação patente entre duas áreas de contraste. Uma está mergulhada numa sombra profunda. A plena luz do sol ofusca a outra. A diagonal que cruza a imagem da esquerda para a direita e liga essas áreas anuncia um encontro futuro. Na parte inferior esquerda, há a imagem de uma garota que ingressa no plano do quadro correndo, enquanto empurra uma roda. No extremo oposto da diagonal, jaz imóvel uma sombra, cujo corpo que a gera está oculto por de trás da arquitetura. A sombra que parece a de um profeta é, no contexto da obra de De Chirico, a de uma estátua. (A mesma estátua que está retratada no quadro O enigma de um dia (1914) (fig.m)). Como a menina na tela aparenta ser feita da mesma substância imaterial de que é feito o vulto parado no ponto antagônico, ela aparece como uma sombra. Se fosse sombra estaria no plano horizontal, nesse caso, a figura do canto oposto deveria estar na vertical, haveria uma inversão dos eixos do quadro. Mas, para manter o quadro na orientação dada pelos prédios, deve-se encarála como menina. De Chirico joga com as normas da representação tradicional, ao retorcer as convenções da perspectiva linear. Há uma incongruência entre as linhas de fugas das duas construções que apontam para linhas de horizonte diferentes, uma nega a outra. Além disso, a sombra do prédio à direita parece feita por um foco de luz diferente daquele que projetou o pequeno traço sob o corpo da menina. A sombra em vez de reafirmar a ilusão volumétrica põe em xeque a ilusão e cria uma espacialidade impossível de se realizar fisicamente, 
um ambiente que não é regido pelas leis naturais nem da física, o espaço metafísico.

Nesse mesmo período, na Rússia, Kasimir Malévitch excluiu completamente a representação e transformou as antigas sombras em um Quadrado preto sobre fundo branco ${ }^{43}$ que, apresentado em 1915, é um dos marcos da pintura moderna. Quadrado preto não referencia, não copia nem alude a um quadrado existente fora do plano do quadro. Na verdade, nem um quadrado é, mas um quadrilátero que se aproxima de um quadrado. Ele é uma construção de tinta sobre tela que existe de forma independente. Não está restrito ao vocabulário da pintura. Afinal, o quadrilátero é uma invenção da mente humana, forma bidimensional por definição, criada abstratamente. Pode ser desenhado por qualquer pessoa, não exige habilidade "artística". "Não é uma forma do subconsciente. É uma criação da razão intuitiva" ${ }^{44}$,segundo o pintor. Ancora-se no conceito de que as artes visuais são autônomas em relação ao mundo real existente fora da obra.

Após a segunda guerra mundial, muitos artistas passaram a utilizar 0 preto e a abstração em suas obras. Clement Greenberg, ao analisar esse fenômeno no expressionismo abstrato, cunha uma hipótese que pode ser ampliada para outros casos. Para o crítico, o extenso uso do "preto e branco tem a ver, de todo modo, com algo mais significativo para a arte pictórica ocidental do que para a oriental". O uso do preto da década de 1950 seria uma reação, e não uma afirmação, da eliminação progressiva da modelagem pelos contrastes entre a luz e sombra, o principal recurso, "muito mais importante do que a perspectiva, para gerar uma ilusão convincente de profundidade e volume" Representam, segundo o crítico, "um daqueles exageros ou apoteoses 
que revelam um temor de perder seus objetos". O uso do preto e branco visaria a compensar a perda da antiga referência, do sombreado no objeto representado como, que guiava o olhar entre os planos do quadro. Seria uma tentativa de conservar e manter, "mediante medidas extremas, um recurso técnico cuja capacidade de produzir forma e unidade convincentes está prestes a se esgotar" 45

O crítico David Sylvester escreveu que o preto era, para os expressionistas abstratos, "seu lápis-lazúli; eles fizeram dele uma mística, em parte talvez por causa de sua austeridade, em parte talvez porque houvesse algo de esplendidamente viril em ser capaz de produzir um preto bem forte". ${ }^{46}$ O preto, na verdade, passou a ser empregado de formas diferentes, como uma cor em meio a outras ou recobrindo totalmente a superfície por vários artistas do mundo. 
Fig.a

Vila dos mistérios Pompéia
Fig.b

Detalhe dosestatutos de l'Ordre du Saint Espirit séc XII
Fig. C

Tintoretto

Ecce Homo ou Pilatos Apresenta Cristo à Multidão (1546-1547)

óleo sobre tela, $109 \times 136 \mathrm{~cm}$,

Museu de Arte de São Paulo
Fig. d

Caravaggio

Judite e Holoferne (1599)

Óleo sobre tela 145x $195 \mathrm{~cm}$

Galeria Nacional de Arte Antiga - Roma 
Fig. e

Frans Hals

Marie Pietrsdochter Olycan

(1635-40)

Ólen cnhre tela $84 \times$ K7
Fig. $f$

Rembrandt

Retrato de Jovem com Corrente de Ouro (Auto-Retrato com Corrente de Ouro), 1635

óleo sobre madeira; 57 × $44 \mathrm{~cm}$, Museu de Arte de São Paulo

Fig. $\mathrm{h}$

Velásquez

Retrato do Conde-Duque de Olivares 
Fig.i

Picasso,
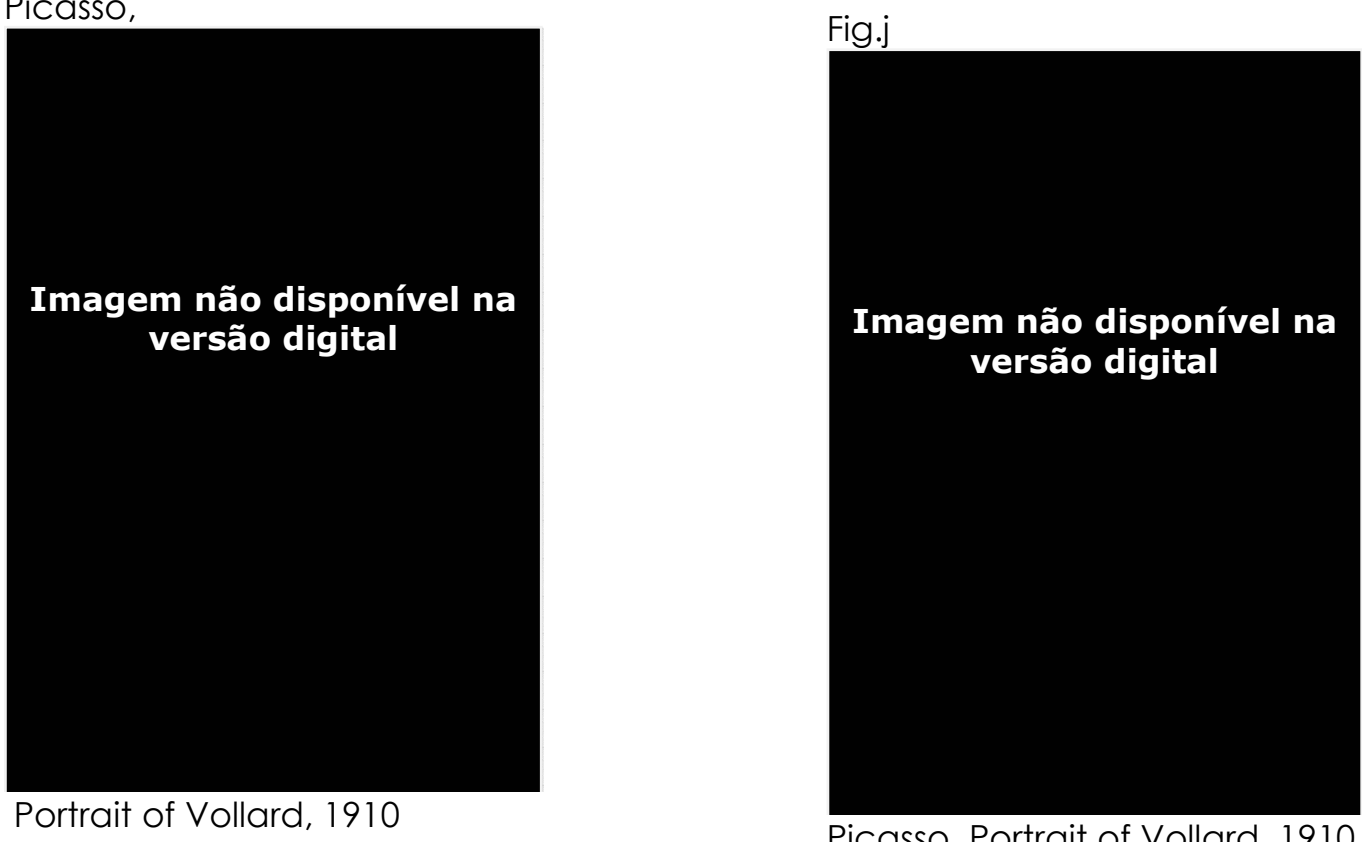

Portrait of Vollard, 1910

Picasso, Portrait of Vollard, 1910

Fig.k

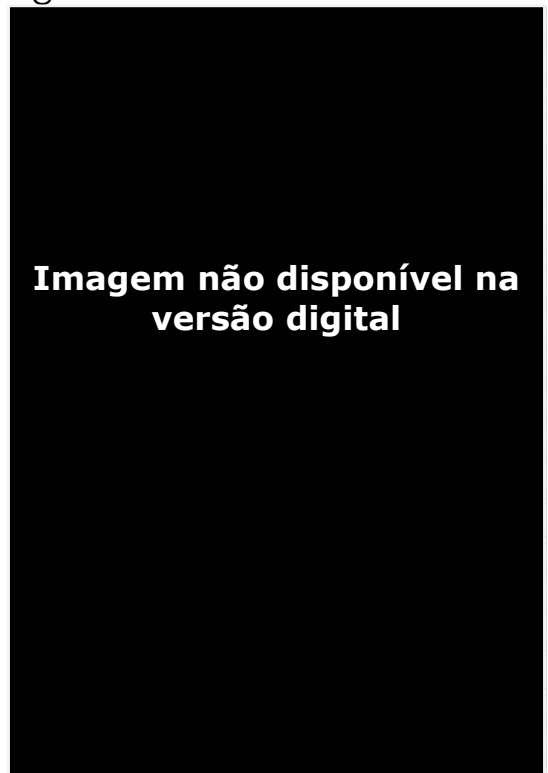

Fig.I

Juan Gris, Le Journal, 1916

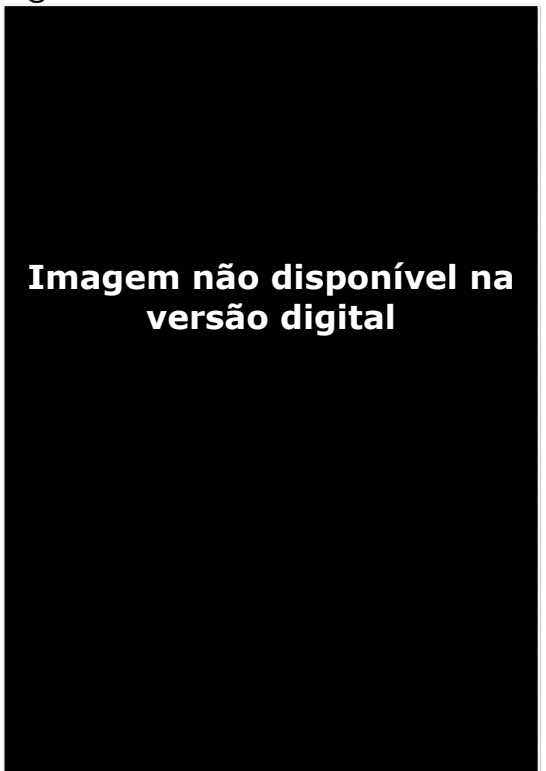

Fig.m

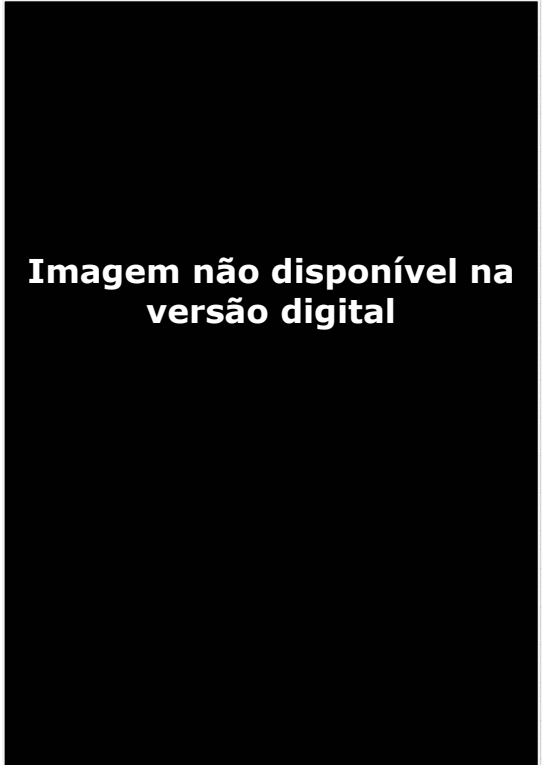

De Chirico

O enigma de um dia(1914) 


\section{Preto como cor.}

"[...] o preto, o preto absoluto de um pequeno chapéu de luto, com suas fitas que se misturavam aos cabelos castanhos, nos quais surgiam reflexos róseos de luz, esse é um preto que podia ser somente de Manet. Preso ao chapéu um largo laço preto dobrado, que surgia por trás da orelha esquerda, circulava e envolvia-lhe o pescoço de uma maneira estranha; um pequeno chalé cobria os ombros para revelar sutilmente a pele clara sob a gola de linho branco.

Essas transições surpreendentes entre pretos intensos emolduravam e enfatizavam uma face cujos olhos demasiadamente escuros possuíam uma expressão distraída e quase ausente."

Paul Valery 47 .

No final do século XIX, na França, diversos artistas se voltavam para o ar livre, buscando capturar as impressões causadas pela luz na retina. Tentavam fixar os instantes fugazes do mundo, ao transformá-los num conjunto colorido e luminoso. Era o impressionismo, que partia da idéia do registro da sensação visual, do registro do modo que se percebe a ação da luz no mundo. Para os impressionistas, a luz revelava o mundo através das cores, da imensa variedade de tons. Sem luz, as cores, e conseqüentemente as formas, esvaecem. Os artistas estavam interessados em registrar a aparência do mundo sob determinada luz, e os efeitos das diferentes atmosferas. Pintavam um mundo cambiante, que não era fixo, mas mutável, pois as cores alteram-se conforme a iluminação, ao longo do dia.

Consideravam a cor composta pelos mesmos elementos do espectro solar, essa variedade de cores devia ser seguida pelas paletas. Procuravam as 
inúmeras variações cromáticas. Destituíram as palavras linha e cor, usadas pelos clássicos e pelos românticos, e substituíram-nas pela palavra "tons", que, analogamente à música, referia-se a uma escala de luminosidade dentro de certo matiz ${ }^{48}$. Um tom não poderia ser analisado isoladamente, devia estar atuando em conjunto, criando contrastes ou harmonias. As cores surgiam, na pintura, por uma mescla ótica das manchas depositadas na tela, e não mais pela mistura de pigmentos na paleta. Os impressionistas pintavam um mundo regido pela luz, no qual até as sombras deixavam de ser a ausência luz, para se tornarem uma luz modificada, com tons baixos, coloridos e não mais compostos de preto. Meyer Schapiro, referindo-se à pintura, escreveu:

"Os impressionistas não estavam interessados no preto. Parte do seu programa era eliminar completamente o preto da tela, como uma cor ausente no espectro, portanto antiluminosa, e nunca usá-la como meio de sombrear ou modelar cores para obter uma tonalidade mais baixa. Era, como os cientistas tinham ensinado, uma não-cor e, portanto parecia incompatível com o ideal de um colorido e luminosidade espectrais naturais. É verdade que Renoir usou o preto como cor local na década de 1860 e no começo da década de 1870 , mas em seu trabalho posterior o dispensou"49

Em meio à fascinação pela luz dos pintores franceses do final do século XIX, Edouard Manet construía seus quadros pela organização de figuras formadas por planos cromáticos. A modernidade industrial modificava a paisagem, as carruagens pretas abarrotavam as ruas, as locomotivas lançavam reflexos ebâneos na paisagem, o carvão era utilizado para manter em movimento a engrenagem industrial e a fumaça cobria a cidade. Manet utilizava o preto para apresentar esse escurecimento que se alastrava pelo mundo. Criava uma obra na qual a casaca, o chapéu e o vestido pretos deixavam de ser roupa, e viravam recortes que, postos numa superfície, transformavam o preto numa cor que potencialmente produzia claridade. 
Para T.J.Clark ${ }^{50}$, Manet revelava a modernidade, não só pelas imagens escolhidas, mas também pela maneira que as pintou. Segundo o crítico, a planaridade, tão marcante nas obras do francês, deixa de ser uma questão puramente formal para ser o enunciado da desconexão entre o que a pintura apresenta e seu modo de apresentação. Foi o modo pelo qual o pintor acusou a modernidade de estar dominada pelas aparências. As superfícies facilmente organizáveis refletem as ambíguas conseqüências da mobilidade e do anonimato da modernidade. Apresentam a frieza, imobilidade, apatia e o aprisionamento como sendo o contraponto da aparente liberdade da nova cidade. A pintura de Manet seria também uma resposta às conseqüências do plano urbanístico do barão Haussmann, que visando a evitar a formação das barricadas em eventuais revoltas populares, transformou Paris num grande canteiro de obras e numa cidade cortada por bulevares. Nessa nova cidade, a vida privada expunha-se pelas grandes janelas de vidro dos magazines e nas mesas dos cafés. As delimitações entre as classes e sexos foram de tal forma esgarçadas que a cidade confundiu-se com um grande espetáculo. Segundo Clark, essa estética do movediço e do indefinido declarou o moderno como o marginal e a verdade da percepção como a superfície das coisas. Indicou ainda que os espetáculos e classes tornam-se formas específicas de visualização. Por isso, a economia visual da pintura, nas obras de Manet, designou sua desconfiança ante a modernidade, se por um lado ele se apropriou dos traços da vida moderna, por outro ele os conjugou com uma profunda exterioridade ${ }^{51}$. Segundo Clark - que vê nas obras de arte um objeto capaz de revelar, na composição formal, as relações históricas e sociais - as telas de Manet revelam a dualidade existente na imagem dos dois princípios que 
caracterizaram a modernidade: de um lado a padronização introduzida pelos processos industriais, do outro, o profundo esvaziamento provocado nas relações sociais.

Manet é considerado um dos primeiros pintores modernos. Mas não foi senão na segunda metade do século $X X$, que o pintor foi elevado a essa condição. Em seu tempo, alguns críticos reclamavam não entender a razão de determinada figura de seu quadro ou espantavam-se com a artificialidade da cena pintada. Vale a pena citar o prefácio escrito em terceira pessoa pelo próprio Manet, para o catálogo de sua exposição individual de 1867. Ele escreveu que os artistas de sua época não chamavam o público para ver obras sem falhas, mas sim "obras sinceras". Ainda afirmou ter se espantando com o fato de acharem que sua pintura fosse algum tipo de protesto, pois ele não protestava ao pintar. "Pelo contrário, bradaram contra ele, e ele não esperava isso. Protestos surgiram porque há um modo tradicional de ensinar as formas, métodos e aspectos da pintura." ${ }^{\text {22 }}$ Complementou que havia, por parte dessas pessoas, tal intransigência, que se oporiam e jamais admitiriam nada que rompesse com as regras pré-estabelecidas.

As normas vigentes determinavam o que era a boa pintura na época. $O$ quadro devia ser uma janela transparente para o mundo. A cena pintada devia estar completamente contida no quadro, ou seja, não devia expandir-se para além da superfície pintada e em hipótese alguma uma personagem poderia encarar o observador. Os pintores deviam lançar mão de uma série de artifícios que direcionassem o olhar do espectador para os pontos-chaves do quadro. Desse modo forneceriam os meios para uma leitura clara da narrativa 
encerrada na tela. Além disso, havia uma hierarquia entre os tipos de pintura, que determinava a escala a ser adotada. Reservavam-se telas grandes às pinturas históricas, religiosas e mitológicas. Lançavam mão da perspectiva linear para criar um espaço virtual contido na superfície delimitada pela moldura.

Manet transgredia esses princípios. Por isso, seus opositores se indignavam ao ver seus quadros. Ao analisar essa reação, Alberto Tassinari não se surpreende com assombro do público pelo "aspecto superficial, e tão pouco instigador de devaneios, da pintura de Manet”. Para o crítico, o pintor transformara sua obra no espelho que refletia o próprio público. "E dava início a esse permanente desajuste - que marca até hoje a história da arte moderna — entre o público e a arte, entre o artista e o mundo."53

As obras de Manet desconcertaram o público não somente pela crua exposição dos meandros da vida moderna, mas também por suas escolhas de composição formal. Apresentava essas relações inovando a linguagem pictórica - a composição de seus quadros remete às colagens, nas quais as figuras são dispostas para atender a uma necessidade interna do quadro e não representar fielmente a realidade externa. Vale a pena frisar que as necessidades internas do quadro, no caso específico do pintor francês, não obedeciam obrigatoriamente às fronteiras geométricas delimitadas pela moldura. Ou seja, Manet criava artifícios para envolver o espectador e extravasar o espaço do quadro, invadindo o espaço real. Com esses vários procedimentos ele criava fissuras no entendimento buscado pelo público, 
pessoas que queriam encontrar na tela emoldurada uma estória, cuja narrativa clara fornecia uma leitura óbvia.

Manet transgrediu essas normas e trouxe questões intrínsecas à linguagem pictórica. Isto é, se antes os grandes mestres - apesar de reconhecerem a materialidade da tela e a tensão entre o espaço ilusório e o plano bidimensional - não queriam deixar explicitas essas questões ${ }^{54}$, Manet, pelo contrário, as explicitou. Michel Foucault ${ }^{55}$ afirmou ter sido Manet, ao subverter o regime clássico de visibilidades, o precursor de toda a pintura do século XX. Manet rompeu com a tradição da arte ocidental, surgida após o quattrocento italiano, fundada no renascimento, de tentar obliterar, mascar ou se esquivar do fato da pintura ser inscrita em um espaço retangular feito de matéria. Manet descartou o dogma que usava linhas oblíquas e espiraladas para esconder o fato de o quadro estar inscrito num quadrilátero de ângulos retos. Suas pinturas assumiam o plano na qual se inseriam. O espaço não era criado pelos códigos da perspectiva linear ou pela ilusão de uma volumetria produzida por variações de claro e escuro. A iluminação das pinturas de Manet coincidia com a posição do observador, vinha de fora do quadro. Era completamente diferente da iluminação clássica oriunda de uma fonte que, para negar a luz do espaço real, raiava de algum local no interior do próprio quadro. Esses quadros desancoravam o espectador, que não tinha mais um ponto de vista fixo.

Manet, o primeiro a deixar transparecer a materialidade da tela, a romper com a ilusão da imagem, o primeiro a incluir a iluminação externa e o primeiro a forçar o observador a percorrer a pintura, segundo Foucault, inventou, ou 
reinventou, o quadro-objeto ${ }^{56}$. Foi o início da autonomia da pintura, o quadroobjeto assume as características objetivas e materiais da tela física. Recusa a profundidade da perspectiva linear, é uma pintura governada pelos eixos verticais e horizontais do suporte, impele a representação para o espectador. 0 quadro-objeto destitui o caráter ideal ou divino de uma fonte de iluminação interna à representação. Instaura um novo foco externo, posiciona a luz no mundo real. No quadro-objeto a representação fomenta a movimentação do observador, que passa a explorar as características físicas da tela. O quadroobjeto está inserido no mundo, e revela os jogos da representação. Por isso, a cor preta inicia seu processo de autonomia. Manet, ao romper o elo entre o aspecto mundo real e a aparência pictórica, faz com que o preto possa ser visto independentemente do objeto retratado.

Se por um lado, Manet se afastava e rompia com a tradição da pintura, por outro, utilizava-a de modo a estabelecer relações deliberadas. Ou seja, o pintor bebeu diretamente na fonte da tradição, para renová-la e para esgarçar os cânones pictóricos da academia. Por exemplo, quando aludia às pinturas dos mestres do passado, ele impregnava seu quadro de toda a história da arte, e isso funcionava para reafirmar que aquilo era um quadro e não aspirava a ser um retrato fiel da realidade. Além de expor os meios de criação da imagem, ele realçava as relações existentes com todo o passado da arte. Alberto Tassinari nos lembra que Manet, inaugurou a arte moderna, ao transmutar o Concerto Campestre de Giorgione, usando um olhar urbano, na tela Almoço sobre a relva. O pintor dispôs, em seus quadros, referências à pintura espanhola, holandesa e italiana, mas devido a seu tratamento inovador, criou relações que transformam e alteram o significado das imagens apresentadas. Declarou 
abertamente a influência exercida e sua admiração por Velásquez, de cujas telas emprestava referências visuais e técnicas deliberadamente, entre elas a valorização do preto e do cinza. Para o francês, o espanhol era o pintor dos pintores, cujas obras o encantavam profundamente, vislumbrá-las "Ihe havia enchido de esperança e coragem de continuar pintando", pois correspondiam às suas próprias idéias de pintura ${ }^{.57}$

Manet descreveu o retrato de um ator da corte de Philip IV, de Velásquez, que em sua opinião era a obra mais extraordinária de todos os tempos. Uma figura vestida de preto, sobre um fundo que desaparece. Velásquez criara uma atmosfera nesse quadro que fez com que a figura aparentasse estar envolvida por nada além do ar. ${ }^{58}$

Manet experimentou criar esse espaço no quadro $O$ Tocador de Pífaro (1866)(fig.1). Pintou uma figura com áreas de cor plana, sem volume, suspensa no espaço dúbio do fundo. A pintura causou tamanho estranhamento que fez com que Coubert afirmasse que uma pintura não deveria assemelhar-se a uma carta de baralho. A planaridade deliberada de Manet opunha-se à ilusão de volumetria da pintura vigente na época, ele rejeitava a ilusão da tridimensionalidade. Por isso retrucou que todos sabiam que o ideal de Courbet era o volume de uma bola de bilhar $^{59}$. No quadro, as duas faixas pretas da calça remetem a grossos traços de uma pintura, transformam o que deveriam ser pernas em duas listras verticais, funcionam como contorno pintado na parte inferior do retratado. São simultaneamente o debrum da calça e a linha de tinta larga que desenha as pernas. Há uma tensão constante entre a figura e fundo. Não é uma relação harmoniosa. A figura parece ter sido recortada de algum 
outro local e posteriormente transferida para o quadro. Por isso a figura flutua, não se ancora, está posta de uma maneira forçada, num espaço sem gravidade. O pequeno rastro de sombra, uma forma cinza sob o pé, não é suficiente para ancorar a figura. A silhueta, assim colocada nesse campo pictórico evanescente, revela o processo de construção da tela: a escolha do objeto, seu enquadramento, a criação do espaço do quadro, a superposição de diversas camadas de tinta.

A assinatura do pintor - colocada quase na diagonal do canto inferior direito do quadro, paralelamente à pequena sombra - funciona como uma indicação dos artifícios usados para dar a ilusão de profundidade, baseados na convergência de linhas para um ponto, na perspectiva linear. Transformada num segmento de reta inclinado, solto no espaço, aponta para uma direção. Sinaliza, mas não completa a ilusão de profundidade, pois o ponto de fuga inexiste. As letras que formam seu sobrenome misturam-se à pintura.

No quadro, o olhar do garoto direcionado para além do espectador transgride o plano pictórico e invade o espaço real. O jaleco é uma superfície preta espessa de tinta. Não há modelagem, não há variação de luz, não há volume. O foco luminoso - que na pintura tradicional seria explicado pela existência de uma janela aberta, uma vela, um lampião, ou qualquer outro artifício - não está no espaço da tela. Os indícios apontam para uma fonte exterior. A sombra, esboçada na mão do menino, é paralela à flauta. Indica, desse modo, uma luz que incide quase perpendicular ao plano do quadro. Ou seja, ela emana do local no qual se localiza o espectador. 
Essa e outras pinturas tinham um aspecto superficial. O pintor usou cores planas, eliminou tanto os claro-escuros quanto os relevos. Ele não iluminava os corpos de maneira a suavizar as formas. "Meios-tons são para os gravadores do Magasin Pittoresque",60, afirmou Manet certa vez. Utilizou uma luz frontal que partia do observador, transformando-o em voyeur. A iluminação tinha a função de fundir personagens e espaço físico num contexto único.

Manet também lançou mão dessa ambigüidade espacial na tela $O$ Artista, retrato de Marcellin Desboutin ${ }^{61}$ (1875),(fig.2) mas diferentemente de o Tocador de Pífaro, no qual a figura digladia com o fundo, aqui há um tipo de suspensão. A pintura foi construída com e por meio da cores sombrias. A figura de corpo inteiro aparece sobre um fundo escuro, criado por uma mistura de preto com ocres, marrons, tons terrosos, do lado direito, e preto e verde, do lado esquerdo. Um olhar mais atento revela uma pequena área, do lado oposto ao cão, na qual aparecem pinceladas alternadas vermelhas, azuis e amarelas. Assim de um lado há pretos mais quentes que paulatinamente se revertem nos pretos frios do lado oposto. Um espaço incerto, no qual não há sequer um esboço de linha do horizonte, nem sequer uma indicação de algum canto de parede. A tela de $192 \times 128 \mathrm{~cm}$ nos parece ser maior, e faz com o boêmio surja como um gigante de olhar absorto a fitar o mundo.

As cores escuras criam um estranho ar noturno. O traje e chapéu pretos reforçam a obscuridade da tela. Somente quebrada pela gola alva e pela iluminação do rosto, das mãos e do cão e dos sapatos pretos que emergem numa luz oxidada, num dourado esverdeado. A cartola inclinada possui reflexos cinza azulados, de um dos lados, destaca-se da cabeleira grisalha, do 
outro, sua sombra faz com que se misture ao cabelo. No traje há diversos pretos. Manet demonstra sua habilidade ao harmonizar tons sombrios com os matizes azul-esverdeados de pretos contra outros pretos. Na manga da mão sem o anel, há uma grossa camada de tinta que dá o limite entre a curva do punho e o resto do paletó. Aqui é a espessura, a matéria pictórica que define as fronteiras entre um e outro preto. As calças, nas quais se percebem as variações de inclinação das pinceladas, foram pintadas sem volume, planas. Formam duas faixas verticais pretas. Uma possui um tom azul mais esverdeado muito escuro, que vai se destacando do fundo mais claro, no qual está o cão. A outra, cuja parte superior é de um preto avermelhado, torna-se um preto azulado abaixo do joelho. Em toda a sua extensão pipocam alguns reflexos cinza-azulados. O preto era a cor eleita para roupas utilizadas tanto pela boemia, quanto pela burguesia parisiense no final do século XIX. Surgiam nos bailes, nos cafés, nos enterros, nas repartições públicas. ${ }^{62}$ Se por um lado, as roupas pretas estavam associadas à sobriedade, ao anonimato - os indivíduos fundiam-se, uns aos outros, criando uma grande massa amorfa uniformemente escura - por outro, estavam também relacionadas à moda, trajes de festa ou ao inconformismo. Mas com Manet, a cor transcende a representação e torna-se um plano carregado de significado: a obra foi alvo de escárnio pela crítica da época que a acusou de ser “... preto de um extremo ao outro, como o retrato de um carvoeiro". ${ }^{63}$

O pintor utilizava o preto como unidade cromática, e a fuligem da modernidade revelava-se em diferentes pretos. Manet afirmou que:

"Cor é uma questão de gosto e sensibilidade. Acima de tudo, você deve ter algo a dizer, senão esqueça. Você não é um pintor a não ser que ame pintar mais que qualquer outra coisa. E um punhado de técnicas não é suficiente, tem de haver um impulso emocional. 
Ciência é muito grandiosa, mas para o artista, imaginação é mais importante. (...) Um dia voltando de Versailles, eu subi numa locomotiva, ao lado do maquinista e do foguista. A visão desses dois homens era magnífica, tão calma e imperturbável, tão estanque! È um trabalho estarrecedor e tanto eles, quanto homens como eles são os heróis verdadeiros do nosso tempo. Quando estiver melhor, pintarei em um quadro com eles"... ${ }^{64}$

Maquinista, foguista, locomotiva, carvão são figuras da modernidade. 0 preto para Manet está no limite entre o escuro reluzente da locomotiva e o carvão. O preto que surge como uma superfície autônoma de cor reforça essa dualidade, essa tensão entre as promessas da modernidade e a o custo a ser pago pelo progresso.

No quadro "As banhistas" (c1882) (fig.3), há duas figuras femininas na superfície: uma maior, sentada no canto esquerdo, e outra menor, que está no meio do quadro. Formas femininas parecem estar arbitrariamente dispostas. A alteração da dimensão das figuras que, quando segue a proporção da perspectiva linear, é um dos instrumentos utilizados na pintura tradicional, para criar a ilusão de profundidade; aqui cria uma estranheza. O campo ilusório não se completa, inexiste qualquer distância para dentro do quadro. Manet lança mão da técnica, usada pelos pintores anteriores ao quattrocento, de diminuir as figuras para criar uma hierarquia, uma distância que é simbólica e não perceptual. A figura maior possui cabelos pretos intensos que emolduram o rosto róseo e caem sobre seu ombro e braço pálidos. Criam uma superfície preta que interrompe o braço esquerdo, destacando-o do resto do corpo. O preto nesse quadro foi usado como uma espécie de solda, que fixa a figura no fundo, e elide a ilusão de profundidade. A cor desse canto da tela mescla o que deveria ser a cabeça, cujo contorno é indistinguível, com o que deveria ser paisagem. Conforme se aproxima da parte inferior, a superfície toma outro 
nuance, passa por pretos esverdeados até transformar-se num castanho. Esse castanho escuro vai transmutando na faixa horizontal inferior: recebe nuances amareladas, que se transformam em esverdeadas, que perdem o amarelo e tornam-se azuladas. Escurecem até alcançar o preto no canto inferior direito. Uma faixa escura horizontal, com pretos, castanhos e cinzas, que ocupa um terço da tela, surge na parte superior, em cujo vértice vêem-se os traços de uma pincelada vigorosa.

Não há distinção entre a íris e a pupila nos olhos pretos. Manet eliminou a subjetividade da figura retratada, como se tivesse apagado a modelo, para criar a forma plástica. As pernas são planas e não se consegue distinguir o volume do rochedo na qual se apóiam. Os pés são formas triangulares, quase autônomas. Se fossem separados da tela, seriam ftriangulos. Há o indício de um pentimento, a posição da perna pintada à esquerda foi alterada, era um pouco mais vertical. Coabitam na pintura o rastro da posição inicial com a posição definitiva, como ocorre em pinturas de Matisse.

A forma feminina menor parece um recorte colocado na composição, seu contorno é bastante arredondado e não guarda as proporções de um corpo humano. O perfil, com o olhar voltado para a direita, expande a pintura para além dos limites da moldura. Diferentemente das banhistas de Cézanne, que estão contidas na estrutura geometrizante do quadro, as de Manet liberam-se para o espaço. Nelas há muito das banhistas pintadas por Matisse, o corpo feminino que se transforma em plástica, proporções que obedecem a urgências construtivas e não representacionais 
Mme. Lefebvre, na tela "A Amazona" (1875)(fig.4) é outra figura feminina cujo preto merece distinção. Rosto róseo e cabelos louros são realçados pelo chapéu e vestes pretas. A aba do chapéu é feita por um tom preto com reflexos ocre. A roupa é chapada, pintada em preto com tons azulados. Não há o menor esboço de volumetria, é uma grande mancha preta. Insinua-se como uma a sombra de um rosto de perfil. Um perfil aquilino e duro, cujo espectro aterroriza a cena. Ao mesmo tempo em que é esboço de uma face é roupa. Porém, quando o observador vê a casaca, tanto o perfil, quanto a superfície pictórica desaparecem. Quando se visualiza a superfície pintada, a casaca some. Mas, ao se ater nessa mancha preta por mais alguns instantes, surge o perfil aquilino, e todo o resto do quadro desvanece. Resta um eco fraco. ${ }^{65}$

A silhueta do cavalo, com a cabeça em diagonal, remete a uma figura eqüestre de Velásquez, o cavalo sem o cavaleiro espanhol à direita do quadro A rendição de Breda. Manet, porém, usa um enquadramento fotográfico: corta o cavalo e a amazona. O conjunto transborda do quadro, a mulher e o animal são projetados para frente, sobre o espectador, no ambiente.

O francês cria também um forte contraste entre o acabamento delicado da figura montada e o tratamento dado ao fundo. A paisagem possui um aspecto não finalizado. Os troncos das árvores, criados por linhas verticais, e a folhagem, formada por pequenos traços horizontais, continuam para além da moldura e criam uma trama que parece uma tapeçaria. É como se o retrato tivesse sido criado num cenário. O chicote na mão da amazona parece roçar essa estampa, assim os cavaleiros na paisagem não parecem distantes, mas sim esboços dispostos quase no mesmo plano da mulher. 
Outro retrato feminino pintado de uma maneira peculiar é Berthe Morisot à l'éventail,(c.1875)(fig.5) no qual a moça está sentada com o rosto escondido sob um leque. Esse leque obstrui a face da modelo e impede que o observador preste atenção naquilo que poderia indicar ou a identidade ou o perfil psicológico da retratada. A sobreposição do leque cria um espectro cadavérico.

A superfície foi preenchida por pinceladas largas e ralas. Há uma urgência no gesto que criou, num movimento rápido e alternado, a superfície marrom do fundo. Ele não diferenciou o plano horizontal, que seria o chão, daquele vertical, que seria a parede. Há somente uma pequena alteração no tom usado, com mais vermelho que o resto, que pode ser tanto essa linha de união entre os planos, quanto uma mancha indefinida de cor. A cadeira, representada somente por parte de uma das pernas e do encosto, não possui indício algum da tridimensionalidade. O segmento aparente do armário - cuja linha diagonal da parte inferior não é suficiente para dar a ilusão de profundidade, pois a linha da parte superior repousa na horizontal - parece um retângulo escuro.

O que mais sobressai nessa tela, composta por manchas marrons e pretas, é um par de formas claras, um par de pés pequenos em relação ao corpo. O vestido, em pinceladas rápidas e ralas de várias nuances de preto, realça a característica bidimensional da tela. São pretos que se sobrepõem e se realçam. Uma das características particulares desse e de alguns quadros de Manet é o fato de que as reproduções fotográficas, talvez pelo fato de homogeneizarem as características materiais da tela, atenuam a planaridade da pintura e, por mais contraditório que possa parecer, deduzem a tensão entre a planaridade e a ilusão de profundidade. A fotografia fixa um instante e o 
comportamento da luz exterior é congelado. Vê-se, portanto, somente uma versão das transformações que a aparência da superfície sofre sob influência da iluminação. Os reflexos luminosos passam a ser na fotografia, uma alteração cromática. Tornam-se, nas reproduções fotográficas, variações de luminosidade que criam a modelagem.

Berthe Morisot foi modelo de várias outras pinturas, entre elas $O$ balcão (1868-1869)(fig.6). Manet deu um tratamento inovador para Las Majas em El Balcon, de Goya. Duas mulheres e um homem estão na cena, cada um olha para um ponto diferente fora do espaço delimitado pela moldura, o que expande o espaço da tela para o entorno, mas, também, passa uma idéia de isolamento: mesmo em grupo, o sujeito está sozinho na sociedade moderna. Manet usou uma iluminação frontal, oriunda de fora do quadro. As três personagens no balcão são expostas a uma luz tão intensa que, além de não haver sombras modeladoras, o interior do aposento às suas costas, que está à penumbra, cobre-se duma escuridão quase intransponível. O vazio é preenchido com opacidade, da qual emergem somente o vulto de um garoto e indícios de alguns poucos utensílios. Existe uma desconexão entre o mundo luminoso na frente da tela e seu interior recoberto de trevas. Manet pintou o interior com vários tons de preto e conseguiu diferenciar o preto sólido da roupa da figura masculina dessa massa escura. Em vez de simular a terceira dimensão pelo jogo do claro escuro, velou o interior e criou uma espacialidade mais rasa e dúbia.

Três cores dominam a tela, verde, branco e preto. Foucault disse que, nesse quadro, o esquema cromático da pintura clássica foi invertido ${ }^{66}$. Antes o 
preto, branco e cinzas eram usados para criar os volumes arquitetônicos, já o colorido era aplicado nas roupas dos personagens. Aqui Manet usa o verde para os elementos arquiteturais, tanto na veneziana quanto no gradil. Aplica o branco nas roupas femininas e o preto na masculina. Além disso, retira da cor preta o caráter de sombreado que produz volumetria e lhe dá opacidade. Assim aplica a ferramenta, antes usada para dar a ilusão escultural da terceira dimensão, para criar profundidade com meios cromáticos, exclusivamente pictóricos, os brancos aproximam e o preto afasta. Inicia o processo de tirar a transparência da janela aberta para o mundo e torná-la uma superfície opaca, formada de tinta sobre um suporte. Sua pintura, uma coisa mental, deflagrou 0 processo que permitiu a criação arte não representativa, ao esgarçar a representação. Apesar de haver ainda a ligação entre as cores do quadro e as cores locais, iniciou o processo que as libertou da representação para serem elementos construtivos. Essa tela, incompreendida no final do século XIX, ecoou fortemente em outras obras da arte do século XX. Matisse retirou os sujeitos, apagou a grade e pintou a Porta-Janela a Collioure. Já Marcel Duchamp converteu o "quadro-objeto" num objeto, fechou de vez a janela e transformou-a numa viúva recente, a Fresh Widow.

Toda a pintura de Manet é figurativa. Mas, também, pelo modo como é executada, sem elidir as qualidades materiais da tela, cria um jogo perene entre a materialidade pictórica e a imagem pintada. Um jogo de presença e ausência, de visibilidade e invisibilidade. Ou seja, ao se perceber a figura deixa-se de ver a materialidade. Quando, porém, a materialidade é focada, apaga-se a referência. Mas, o jogo entre a materialidade e a imagem, tão forte 
na obra, é atenuado e, por vezes, desaparece das fotografias tiradas dos quadros.

Na reprodução fotográfica de Portrait de Nina de Callias,(fig.7) vê-se uma mulher deitada num divã. Há vários leques japoneses colocados na parede. Sua roupa preta remete a um leque, como aquele que cobre o rosto de Berthe Morisot no quadro comentado anteriormente. No lado esquerdo, uma sombra invade o divã e a parede. Mas não há nenhum outro personagem na cena, essa é, portanto, uma sombra de alguém que está fora do espaço do quadro. Manet, ao incluir sua própria imagem delineando-a frontalmente, retirou quaisquer singularidades que permitiriam a associação entre a mancha e ele. Uma sombra de perfil mostra detalhes, o nariz, testa, queixo etc., que pode indicar para um sujeito. Uma sombra frontal não apresenta singularidades, pode ser a de qualquer um.. ${ }^{67}$ Pode ser tanto o pintor, quanto do observador. Essa sombra não tem foi pintada para criar ilusões de profundidade, mas para unir o espaço do observador com a superfície da tela. No mundo físico, o efeito da sombra projetada é a eliminação do volume dos corpos. É a transposição direta de um mundo tridimensional para o bidimensional.

A tinta preta da roupa foi depositada com pinceladas largas e espessas, cria um campo brilhante e profundo, tão intenso, que é negro. Um campo que cria luz e parece invadir o espaço do espectador. Ao observarmos esse negro, o resto da tela perde o foco. A luz negra vibra e apaga a modelo e a cena pintada. Mas ao focarmos o quadro como todo, o negro torna-se saia preta e a matéria some. A matéria é assentada em zig e zag. As pinceladas amplas 
deixam o rastro das cerdas do pincel, e é nessas ranhuras que a luz brinca com o negro e, em vez de ser absorvida, jorra para o ambiente.

Manet realça as feições femininas, ao contrastar as peles rosa-pálidas com negros intensos. E o charme inesperado de uma "jóia rosa e preta"68 reverbera em outros quadros, como no retrato Berthe Morisot e o buquê de violetas (1872)(fig.8). A paleta escura, a habilidade de harmonizar pretos sobre pretos, considerada pelos detratores uma falha, uma cópia imperfeita dos espanhóis ${ }^{69}$, para outros era reconhecida como trunfo. Paul Valery elogiou essa capacidade de criar uma riqueza de pretos. Afirmou que o que mais o impressionara nessa figura de olhar vago e pensamentos inatingíveis fora, acima de tudo o preto absoluto, que só poderia ser de Manet, naquele pequeno chapéu. ${ }^{70}$.Para Valery, o pintor fez poesia com a utilização de pretos poderosos que contrastam com a pele pálida ${ }^{71}$.

Os pretos contrastam tanto com os tons róseos da pele, quanto com os tons violeta-azulados do fundo - um espaço claro que possui faixas verticais de luminosidade difusa, cada qual de intensidade diferente. Além disso, a massa pictórica faz com que a luz incidente, em vez de ser dragada e absorvida pelo preto, ricocheteie e volte para o ambiente, luzindo.

A capacidade de criar diferentes pretos pode ter relação com uma experiência de viagem que tivera na adolescência. Manet afirmou tinha aprendido muito sobre pintura na sua viagem ao Brasil, na qual passara "infindáveis noites olhando o jogo de luzes e sombras da esteira do navio", e aprendera a capturar um céu ao observar durante todos os dias o horizonte a partir do deck superior ${ }^{72}$. Manet, aos 16 anos, tinha aprendido coisas sobre 
pintura ao observar o rastro do navio no mar e o encontro distante do mar com o céu. Um mar que, à noite, se torna uma superfície negra, com ondulações que reagem à incidência de luz, apresentando reflexos fugidios das mais variadas tonalidades. $\mathrm{O}$ jovem revelava assim sua sensibilidade às nuances pretas, aos jogos de luz e escuridão que agem numa superfície e criam o negro. 
Fig. 1

Manet

O Tocador de Pífaro(1866)

Óleo sobre tela

Musee d'Orsay Paris
Fig.2

Manet

O Artista, retrato de Marcellin Desboutin , ( 1875) óleo sobre tela

Museu de Arte de São Paulo - MASP
Fig,3

Manet

As banhistas (c1882)

óleo sobre tela

Museu de Arte de São Paulo - MASP
Fig.4

Manet

A Amazona(1875)

óleo sobre tela

Museu de Arte de São Paulo - MASP 
Fig.5

Manet

Berthe Morisot à l'éventail(c.1875)

Óleo sobre tela

Musee d'Orsay Paris
Fig.6

Manet

O balcão (1868-1869)

Óleo sobre tela $169 \times 125 \mathrm{~cm}$

Musee d'Orsay Paris

Fig.7

Manet

Portrait de Nina de Callias(1873-1874)

Óleo sobre tela $113 \times 166 \mathrm{~cm}$

Fig.8

Manet

Berthe Morisot e o buquê de violetas(1872)

Óleo sobre tela $55 \times 38 \mathrm{~cm}$

Musee d'Orsay Paris 


\section{Preto interior}

Tornar-se pintor é como tatear o caminho num quarto escuro atulhado de coisas. Quando começa a andar, ele tropeça no sofá de outra pessoa, muda de direção para colidir com a cômoda de alguém, depois tromba com uma mesa de trabalho que não pode ser desarrumada. Tudo tem seu uso e seu usuário e nenhuma necessidade dele.

\section{Leo Steinberg ${ }^{73}$}

Van Gogh é um artista que deixou seus pensamentos bem documentados, em diversas cartas escritas no final do século XIX. Porém, o teor dramático de sua vida é geralmente o viés usado para a leitura de suas missivas. Enfatiza-se a versão de um pintor ensandecido, cuja visão distorcida do mundo era retratada, violentamente, pelo uso intuitivo de cores. A loucura é um tema muito mais explorado do que sua cultura sobre a essência da pintura. Van Gogh era um pintor culto, lia sobre arte e freqüentava museus. Possuía um profundo conhecimento das teorias das cores vigentes na sua época. Refletia e aplicava esse conhecimento em seus quadros.

Em cartas de 1882, enquanto ainda pensava que um pintor devia retratar as cores locais, defendeu a aplicação do preto na pintura. Van Gogh pensava no preto como modo de escurecer outras cores, de criar cinzas. Apesar de concordar com a inexistência do preto absoluto na natureza, em sua opinião o preto e branco poderiam ser usados na composição de várias cores. O uso do preto permitia a criação de cinzas diferentes em tom e em força. Bastava observar que na natureza viam-se muitos desses tons e sombras. Pela adição de branco e pretos às outras cores, tem-se cinzas avermelhados, cinzas 
azulados, cinzas amarelados, cinzas esverdeados. Adicione-se a variedade infinita de variações dentro de cada um desses cinzas para ter uma paleta. Para ele, o conhecimento das regras básicas da mistura de cores pigmento valia mais que ter ao seu dispor muitos tubos de cores diferentes. Afinal, muitas cores poderiam ser criadas com as seguintes regras simples:

"existem, porém, três cores fundamentais: vermelho, amarelo e azul; as compostas são laranja, verde e violeta. Ao adicionar preto e um pouco de branco obtêm-se infinitos cinzas: um cinza avermelhado, um cinza esverdeado (...), ${ }^{, 74}$

Para Van Gogh, nessa época, o bom colorista deveria ser capaz de identificar a composição de uma cor na natureza, e saber, por exemplo, "que aquele verde-acinzentado é amarelo com preto e azul" ${ }^{75}$ Van Gogh, numa época na qual a luz fascinava os pintores, vislumbrava as possibilidades de uma paleta escura, capaz de retratar os interiores claustrofóbicos e empoeirados. Ele havia lido, "Maitres d'Autrefois" do pintor e escritor francês Eugène Fromentin, um livro que tratava questões sobre as cores. Van Gogh retirou dessa leitura respostas para as dúvidas sobre o uso uma gama cromática mais rebaixada, como o esquema que tinha ouvido do pintor holandês Israëls no Museu Hague. Por isso, cogitou as possibilidades de usar o preto para clarear cores escuras, para expressar, enfim, a luz por oposição a escuridão. Contrariou a opinião do irmão Theo que compartilhava a opinião dos impressionistas de que não se deve usar "muito preto". Em 1884, Van Gogh ainda não havia visto as obras dos impressionistas, por isso afirmou que o modo de pintar dos impressionistas não Ihe comovia nem lhe interessava. As pinturas antigas, mais escuras, mais densas, sim. O pintor lamentava que os pintores, seus contemporâneos, o privassem do bistre e do betume. Afirmava que, apesar das dificuldades de utilização, esses materiais engrandeciam o 
colorido. Estava conseguindo utilizá-los, após um ano de tentativas. Van Gogh, nessa época, nem sempre empregava o preto puro, apesar de defender seu uso. Aplicava um tom de betume e bistre para dar o claro-escuro quente de um ambiente fechado e empoeirado. Misturava azul da Prússia com o siena queimado, que criavam tons mais profundos, dependendo do efeito desejado. ${ }^{76}$.

Van Gogh começou a afirmar que as cores da pintura não devem ser obrigatoriamente as cores locais, e, portanto, mesmo sem haver preto na natureza, um colorista pode lançar não dessa cor. Ele não estava convencido que um céu nublado, por exemplo, devesse ser sempre pintado em tom local. Citou por exemplo que Ruysdael , Dupré e Corot não usavam cores locais ${ }^{77}$

Van Gogh estudou teorias da arte, vale a pena transcrever um trecho um pouco longo de uma carta - na qual ele pede ao irmão para comprar livros de arte, que tratem de questões teóricas e técnicas da arte:

"Eu pretendo estudar seriamente a teoria. Não penso que isso seja inútil, e eu creio que aquilo que sentimos por instinto ou intuição fica geralmente mais definido e claro se nos fundamentarmos em textos realmente práticos.

Mesmo que haja somente uma ou poucas coisas nesse tipo num livro, vale a pena não somente lê-lo, mas inclusive comprá-lo, principalmente hoje em dia.

Na época de Thoré e Blanc existiam pessoas que escreveram coisas que já estão sendo esquecidas. Para lhe dar um exemplo:

Você sabe o que significa um tom-inteiro e um tom-rompido ${ }^{78}$ ? Claro que você pode vê-los num quadro, mas você poderia explicar aquilo que vê? O que se quer dizer com rompido? Há algumas coisas que devemos saber teoricamente também, seja numa atividade prática de pintor ou ao discutir as cores como um especialista.

A maioria das pessoas atribui-Ihes significados subjetivamente aleatórios, mesmo que essas palavras tenham uma definição muito específica.

As leis das cores são de uma beleza inefável, simplesmente por não serem acidentais. Da mesma maneira que, atualmente, as 
pessoas não acreditam mais em milagres fantásticos, não acreditam mais em um Deus que voe caprichosa e despoticamente de um lugar a outro, mas começam a sentir mais respeito, admiração e fé na natureza- do mesmo modo, e pelas mesmas razões, creio que em arte, a idéia fora de moda de um gênio inato, inspiração etc., - não quero dizer que devam ser excluídas, mas devem, sim, ser reconsideradas completamente, verificadas e modificadas enormemente. Entretanto eu não repudio a existência do gênio, mesmo inato, Mas, certamente eu rejeito a inferência que a teoria e a erudição sejam, nesse caso, sempre inúteis" ${ }^{79}$

Van Gogh passou a citar explicitamente os livros Lês Artistes de mon temps e Grammaire dês arts du dessin, de Charle Blanc, cuja leitura influenciou tanto sua opinião sobre arte, quanto sua prática pictórica. Após a leitura de Blanc, o pintor passou a explorar e usar conscientemente questões relacionadas às cores, ao contraste simultâneo pela aplicação de cores complementares, o uso de sombras coloridas. Passou a desprezar o uso das cores locais. Verbalizou essa mudança de opinião, por exemplo, quando transcreveu um trecho de Lês Artistes de mon temps no qual Blanc citou um encontro com Delacroix, no qual ambos comentaram sobre a grandeza de não se retratarem os tons locais e Delacroix apontara o chão sujo e disse que se pedissem para Veronese usar esse cinza sujo para pintar uma mulher loira "ele a pintaria, e seria uma mulher loira em sua tela"80.

Nas cartas, Van Gogh defendia uma autonomia cromática para a pintura, as cores não deveriam ser miméticas, mas servir às questões e leis próprias da pintura, mas nesse período em 1885, as cores de sua pintura ainda não estão livres do modelo:

"Como eu the contei, achei muito boa sua carta sobre o preto, e aquilo que você diz sobre não usar as cores locais está certo. Mas isso não me convence. Em minha opinião, há muito mais por trás de não usar tons locais. Les vrais peintres sont ceux qui ne font pas la couleur locale [os verdadeiros pintores são aqueles que não ligam para as cores locais] - foi o que afirmaram, certa vez, Blanc e Delacroix (...) Eu mantenho da natureza a seqüência e correção para colocar os tons, eu estudo a natureza, para não fazer coisas tolas, para me manter coerente. Entretanto, não ligo se as minhas cores 
não correspondem exatamente, desde que pareçam tão bonitas na minha tela,quanto na natureza., ${ }^{\prime}$

Van Gogh encontrou, no uso das cores complementares opostas, uma maneira de criar uma pintura com cores vibrantes, que ao mesmo tempo fossem harmônicas. Aos três pares de opostos de cores complementares: amarelo e violeta, vermelho e verde, e azul e laranja, ele acrescentou os opostos de luminosidade: o branco e o preto. O pintor associava o uso do preto ao contraste de claro e escuro, interpretou o preto e o branco como uma quarta gama de cores, mesmo que fossem cores neutras. Assim, o branco poderia ser considerado a mais alta combinação entre os mais luminosos vermelhos, azuis e amarelos. Já o preto seria a mais alta combinação entre os mais escuros vermelhos, azuis e amarelos. Portanto, o tom do claro e do escuro, no que diz respeito à sua luminosidade, está em relação direta com esta quarta escala do branco ao preto.

\begin{tabular}{|c|c|c|}
\hline Gama 1 & do amarelo & ao violeta \\
\hline Gama 2 & do vermelho & ao verde \\
\hline Gama 3 & do azul laranja \\
\hline Soma & BRANCO & PRETO \\
\hline $\begin{array}{l}\text { (aquela gama dos tons } \\
\text { neutros, vermelho+ azul+---------- } \\
\text { amarelo) }\end{array}$ & (vermelho+azul+amarelo, (Vermelho+azul+amarelo, \\
muito claros) & mais profundamente \\
\hline
\end{tabular}

82

Van Gogh concordava com seu irmão que o preto não existia na natureza, e em momentos de dúvida cogitava se o preto existiria ou não na cor. Em 
momentos de certeza, lembrava que os coloristas usavam preto misturado com outras cores. Mostrava como o emprego do preto criava tensão cromática. Referia-se ao comentário de Charles Blanc em Les Artistes de mon temps sobre os cinzas frios e incolores empregados por Velásquez em suas sombras, que eram oriundos de mistura de um pouco de preto com branco e, justamente por serem tão neutros, realçavam qualquer pingo de vermelho empregado. ${ }^{83}$.

O pintor estudou as possibilidades de utilização do preto como cor. Ele analisou a riqueza cromática dos pretos de Frans Hals, que criara não menos que 27 pretos, entre os quais, um preto chapado e dois pretos-violáceos: um preto-violeta-avermelhado e um preto-violeta-azulado. Van Gogh concluiu que tanto o preto quanto o branco têm sua razão em existir, e tentar suprimi-los seria um erro terrível. Bastava ver o uso que Rembrandt, Hals e Velásquez fizeram do preto. $^{84}$ Vincent apresentou o esquema cromático de Os pescadores de Zandvoort de Israëls - pintado com vermelho, azul, amarelo, com preto e um pouco de branco sujo com marrom, todos misturados e quebrados. Observou que Israëls não excluiu o preto de sua paleta, que por mais escura que fosse, criava sombras pretas-coloridas. ${ }^{85}$

"Você - que está olhando para as sombras escuras em algum lugar - pensa que está tudo errado quando as sombras estão escuras, isso é pretas, certo? Eu discordo. Por exemplo, estariam errados o Dante de Delacroix, ou Pescadores de Zandvoort. Pois na verdade eles possuem os mais vigorosos preto-azulados ou pretovioláceos. Rembrandt e Hals não usaram preto? e Velásquez?

Não um somente, mas vinte e sete pretos, eu garanto. Portanto, você sabe o significado da afirmação 'o preto não deve ser utilizado', ou o que você deseja com ela? Realmente, reflita cuidadosamente e você concluirá - como creio que o fará - que você aprendeu e interpretou erroneamente as questões sobre os tons, ou aprendeu superficialmente e entendeu vagamente, assim como a maioria das pessoas. Mas com o tempo, Delacroix e outros de sua época farão com que você entenda"86 
Sua paleta estava escura, nota-se grande influência de Israëls, Rembrandt e Frans Hals, na segunda metade de 1885. "Por falar em preto - quanto mais eu vejo as pinturas que tem um esquema cromático frio e infantil, mais eu fico feliz de que achem meus estudos muito pretos" ${ }^{\text {"87 }}$ escreveu Van Gogh. Afirmou ter utilizado deliberadamente, numa pintura de ninhos, o preto como um fundo pictórico e não como reprodução fiel da natureza. Ele criou esboços com o fundo preto que "possuem sua alta luminosidade posta numa escala de cores mais baixa que as da natureza",88.

Van Gogh, influenciado pela leitura de Blanc, acreditava que questões relacionadas às cores complementares, contraste simultâneo e a neutralização dos complementares fossem as principais questões da pintura. Seguidas das questões relacionadas à mútua influência de cores análogas, como por exemplo, a influência do carmin sobre o vermilion, ou de um violeta-rosado sobre um violeta azulado. E por último deviam ser pensadas as questões sobre a luminosidade de um mesmo matiz, ou seja, um azul claro, sobre o mesmo azul mais escuro.

O artista começava a pregar o uso de cores autônomas nas pinturas, mas o enunciado em cartas não surgia traduzido nas obras. Ele usava ainda tons focados nas cores locais, e modelava a pintura baseando-se nas alterações de luminosidade. O preto estava presente em sua paleta, mas está ainda a serviço das sombras ou da cor local, ainda que esboçasse alguma autonomia. Mesmo ocupando uma grande área do fundo o preto ainda é sombra em Carroça com boi branco e vermelho (1884)(fig.9) e na Natureza Morta com três ninhos de pássaros (1885).(fig.10) O preto, mesmo criando tensão com o pote branco é 
garrafa e sombra na Natureza morta com quatro garrafas de pedra, Frasco e tigela branca (1884)(fig.11) e na Natureza morta com prato vasos e flores (1884-1885) (fig.12)

Van Gogh escreveu sobre os princípios que orientavam sua prática, mas há uma defasagem entre 0 momento da formalização verbal e da transformação em obra de arte. Enquanto tentava racionalmente inserir os princípios de sua da teoria em suas pinturas, sua paleta era vassala do tema, tributária ao que estava sendo retratado. O preto do retrato de uma mulher com fita vermelha (1885)(fig.13) é cabelo:

"a cor de pele cheia de variações tonais, um pouco mais bronzeada no pescoço, cabelos pretos intensos, preto que eu tive de fazer com carmim e com azul da Prússia; um quase branco para a blusa, um amarelo muito mais claro que o branco para o fundo. Uma nota de fogo nos cabelos de pretos intensos....89.

Van Gogh saiu do interior da Holanda, foi para Antuérpia e depois para Paris, onde ficou de 1886 a 1888. Freqüentou exposições. Mantinha-se atualizado com as questões estéticas de sua época, lia bastante e participava de conversas com vários artistas, entre eles, Signac, Pissarro, Seurat, Toulouse-Lautrec e Gauguin. Durante o período parisiense, alimentou-se da estética impressionista, mas digeriu-a a seu modo, jamais a abraçou integralmente. Pintou muito, fez quadros à maneira de vários dos outros artistas, estava procurando o seu próprio estilo. Aquilo Ihe apontava o caminho, mas não era o caminho que ele seguiria.

Após mudar-se para Arles no Sul da França, escreveu sobre o esmaecimento do que aprendera em Paris e sobre a retomada das idéias que Ihe surgiram anteriormente na Holanda: 
"Aquilo que aprendi em Paris está me abandonando, e eu estou retomando as idéias que eu tinha no campo antes de ter conhecido os impressionistas. Não ficaria surpreso se os impressionistas logo achassem defeitos no meu modo de trabalhar. Pois, em vez de tentar reproduzir exatamente o que tenho sob os olhos, eu uso a cor de modo mais arbitrário para me exprimir poderosamente",90.

Van Gogh reagia ao método de Seraut e Signac que cobriam a superfície em pequenas pinceladas de cores puras que, devido a ação mútua, criavam uma síntese cromática na retina. Ou seja, os vários pontos coloridos da tela formavam outra cor no olho ${ }^{91}$ As cores aplicadas nesse processo, em vez de se realçarem, acabam por se neutralizar e muitas vezes criam uma superfície acinzentada.

Reforçado pela inspiração das gravuras japonesas, com as quais já tivera contato desde seu período em Antuérpia, rompeu tanto com as influências de seu passado holandês quanto com as influências francesas. Como escreveu Meyer Schapiro, a estética japonesa serviu de álibi para que Van Gogh praticasse sua arte, "uma justificativa prática para sua independência das formas estabelecidas. A arte japonesa deu a Van Gogh, como ele disse, a autoridade de introduzir contrastes de branco e preto puros"92 em sua paleta. Ele passou a colocar o branco e o preto impolutos, saídos dos tubos, em seus quadros. "Uma simplificação de cores à japonesa" que ignora a interferência das cores refletidas, e coloca os tons básicos chapados, lado a lado, com linhas para demarcar as formas. Esse aplanamento permite pintar um cavaleiro vestido de preto, "com negro de osso comum", e as folhas do livro que o homem lê com branco simples, sem mistura ${ }^{93}$. Van Gogh considerava, então, o branco e preto cores, cujo "contraste simultâneo é tão perturbador quanto a justaposição de verde com vermelho" ${ }^{24}$. E usava como exemplos trabalhos 
japoneses, nos quais havia o embate entre os cabelos pretos brilhantes e a pele alva e fosca de uma menina, ou "seus espinheiros pretos, nos quais mil flores brancas se destacam como estrelas"95

Van Gogh passou a usar a cor de forma mais autônoma, mesmo se inspirada na natureza, a partir de 1888. Tornou sua pintura mais expressiva que o modelo. $\mathrm{O}$ pintor interiorizou o que antes servia como amarras racionais: suas leis das cores. Havia um conhecimento profundo, mas não era teorizado, conseguia pintar o inexprimível. Sua pintura, jamais ingênua ou puramente intuitiva, fluía. As cores deixam de retratar exclusivamente o visível, e começam a traduzir o indizível. O olho e a mão passaram a ser acompanhados da imaginação, "a única (faculdade) que pode levar a criação de uma natureza mais exuberante e ao mesmo tempo mais consoladora do que um único relance sobre a realidade." ${ }^{.96}$ Somente quando a sua paleta clareou e as questões cromáticas foram incorporadas no fazer poético e não racionalizadas, o preto livrou-se da condição de sombra e passou a ser uma cor ativa dentro dos quadros, participando do jogo de tensão entre os campos coloridos. Quando a teoria dos contrastes foi interiorizada, e não mais intelectualizada, as cores ganharam toda a força e violência tão típica da pintura de Van Gogh. Merleau-Ponty assinalou o processo, tão extenso, intenso e árduo, pelo qual um pintor deve passar para a constituição de seu estilo pessoal. Um movimento contínuo, no qual as primeiras obras se relacionam com a produção madura, simplesmente por terem efetivado "certas operações expressivas" que servem para capacitar o artista a ir mais longe. $O$ "esquema interior" que, quando muito se insinua discretamente nas obras iniciais, converte-se em modo "universal de compreender e fazer compreender, de ver e dar a ver - 
portanto não encerrado nas profundezas do indivíduo mudo, mas difuso em tudo quanto ele vê" ${ }^{n 7} \mathrm{O}$ estilo não é um conjunto de procedimentos e truques arroláveis , pois "nasce à revelia" do pintor, mas é um meio individual de formulação da mundo na tela facilmente identificável pelos outros.

O artista, sem jamais abandonar a teoria, percebia outros significados para as cores. Numa carta, na qual queria dissuadir Emile Bernard de pintar temas religiosos, demonstrou como a combinação das cores podia transmitir sensações mais fortes que uma cena bíblica. O preto emprestaria significado à composição, como fez notar em sua descrição do quadro $O$ jardim do manicômio em Saint-Rémy (1889)(fig.14):

“ (...) O extremo do jardim está plantado com grandes pinheiros com troncos e galhos ocre-avermelhados, a folhagem verde foi escurecida com uma mistura de preto. (...) A árvore mais próxima tem um tronco enorme mas foi atingida por um raio e serrada. Entretanto, um galho ainda se projeta para cima no ar e joga para baixo uma chuva de agulhas verdes. Esse gigante sóbrio - com seu orgulho ferido -contrasta, se você emprestar-lhe características humanas, com o sorriso pálido da última rosa no arbusto murcho na frente dele. Sob as grandes árvores, bancos de pedra vazios, cercas vivas fúnebres, o céu refletido - amarelo - em poças d'água da chuva. 0 raio do sol torna o ocre em laranja com seu ultimo reflexo. Figuras pretas pequenas vagueiam entre os troncos de arvores.

Entenderás que essa combinação de ocre avermelhado, de verde entristecido com cinza, e o uso traços pretos densos que delimitam os contornos, produz um pouco a sensação de angústia, chamada "noir-rouge", da qual padecem freqüentemente alguns de meus companheiros de desventura. Principalmente o efeito da grande árvore fulminada por um raio, e o sorriso rosa-esverdeado doentio da última flor do outono servem para acentuar essa idéia"98

No texto, Van Gogh não fornece uma relação unívoca entre uma determinada cor e um sentimento. Atribui a sensação de angústia não ao preto, ou ao ocre avermelhado ou ao verde entristecido, mas à "combinação de ocre avermelhado, de verde entristecido com cinza, e o uso traços pretos densos que delimitam os contornos". 
Em outros quadros o preto também tem significado. Albert Aurier numa crítica veiculada em 1890 na publicação simbolista Mercure de France, descreveu os ciprestes pintados com preto por Van Gogh como uma natureza entre o realismo e o sobrenatural, que sob um céu com brilho de safiras e turquesas, surgiam "retorcidos como gigantes em batalha" e expunham "suas silhuetas pretas flamejantes pesadelares" ${ }^{\prime 99}$. O preto aqui deixa de ser somente Ciprestes (1899)(fig.15), mas, ao contrastar com o azul, passa a simbolizar uma peleja árdua, um duelo entre forças descomunais. Van Gogh interpreta essa afirmação como um reconhecimento da existência do preto como cor: "Aurier, também, está ciente disso, ele diz que mesmo o preto é uma cor, e refere-se a sua aparência flamejante". ${ }^{100,}$

Van Gogh encantou-se com os ciprestes escuros, tão característicos da paisagem da Provença. Afirmou que eram mais belos que um obelisco egípcio. Os ciprestes representavam "uma mancha escura na paisagem ensolarada, mas é de um tom preto dos mais interessantes, muito difícil de produzir"101. Em um de seus estudos, ele representou um conjunto de ciprestes na frente de um campo de trigo durante o mistral de um dia de verão. As árvores retorciam-se num combate às forças eólicas, tentavam resistir à violência da natureza incontrolável e instável das rufadas. Árvores pintadas "como um toque preto no azul cambiante do amplo céu azul, com o vermillion das tulipas contrastando com esse toque preto"102.

Em Corvos sobre Campo de Trigo (1890)(fig.16), os caminhos são formados linhas excêntricas, é impossível alcançar o horizonte. Meyer Schapiro vê os corvos pretos avançarem, "do horizonte para o primeiro plano, invertendo 
com sua aproximação a passagem normal do espectador para a distância; este é assim por dizer, o foco e o ponto de fuga dos pássaros" Os corvos são ameaçadores, nessa interpretação, "figuras mortais vindas do longínquo horizonte." ${ }^{103}$ Mas, o movimento dos corvos é dúbio, pode ser interpretado como aproximação ou afastamento. Pode ser um grupo de pássaros que lutam contra a intempérie para alcançar seu lugar. Van Gogh utilizou-se de uma metáfora de pássaros, numa carta a seu irmão, dez anos antes de ter pintado esse quadro. Ele se comparava a um pássaro preso numa gaiola, que durante a primavera, sabe que há algo além da gaiola, mas sua memória é turva, tem lembranças vagas sobre a vida dos pássaros fora da gaiola, tenta libertar-se em vão. Mas ao chegar o período da migração, ele gostaria de voar com os outros pássaros e enfrentar a tempestade ${ }^{104} \mathrm{O}$ vôo representaria a liberdade, e a tempestade o custo de sobreviver em meio a essa liberdade, uma espécie de redenção.

Mas esse mesmo quadro fornece possibilidades de outras interpretações, o próprio pintor via a paisagem que retrataria como uma miscelânea incongruente de tristeza e aconchego. Van Gogh ora descreveu as "imensas extensões do trigal sob um céu agitado", das quais ele não recuara "perante a possibilidade de exprimir tristeza e a enorme solidão" e ora aspirava a que seus quadros fossem capazes de transmitir, aquilo que ele foi incapaz de pôr em palavras, "a saúde e o vigor da vida do campo". ${ }^{105}$. O conflito dessas afirmações não deve ser visto como um sinal de um desequilíbrio do pintor. Pois, em diversas outras cartas, muito anteriores a esse período, Van Gogh via a natureza como uma moeda que possui dois lados. Encarava a natureza como a coexistência dos opostos. Por exemplo, descreveu certa paisagem holandesa 
que, sob o sol escaldante do meio dia, podia ser incomoda, desértica e hostil mas ao cair da tarde, quando a extensão árida ficava escura em oposição aos sutis tons violetas do céu, essa mesma paisagem tornava-se sublime. ${ }^{106}$

Descreveu, também, as turfeiras na Holanda nas quais os carvalhos mortos surgiam soterrados sob a lama preta da turfa, uma paisagem absolutamente melancólica e dramática, mas conforme Van Gogh bela tanto por ser um local de paz, quanto pela característica trágica. A turfa preta se, por um lado, é formada pela morte dos carvalhos, por outro, é um terreno fértil. ${ }^{107}$

Assim como o quadro Café Noturno, no qual Van Gogh queria "exprimir que o café é um lugar onde podemos nos arruinar, enlouquecer, cometer crimes". Para alcançar esse efeito lançou mão dos contrastes de cor-de-rosa, vermelhos e vinhos contra verdes suaves e vários verdes fortes, para criar uma "infernal atmosfera de fornalha, de enxofre pálido, exprimir algo como o poder das trevas de uma espelunca". Porém ao mesmo tempo mantendo "uma aparência de alegria japonesa e da bonomia do Tartarin"108

A solidão, outra referência dúbia em cartas de Van Gogh, não tem somente a carga negativa, pode fomentar a reflexão. "Até o momento, no entanto, a solidão não me incomodou muito, de tão interessante que eu achei o sol mais forte e seu efeito sobre a natureza", ${ }^{109}$ favorece a percepção do mundo. Uma solidão que podia ser produtiva, pois mesmo estando isolado, as idéias Ihe vinham em abundância, tornando-o "uma locomotiva de pintar"110.

A própria escolha de conseguir a harmonia no quadro pelo emprego de contrastes, de combates entre cores, não revela insanidade, mas uma opção coerente de retratar a estranheza do mundo. Uma obra que apresenta a 
coexistência de dualidades. O caos e a procura da ordem, a ausência e a presença, o isolamento e aproximação não surgem como pares separados e discrepantes. Eles são pintados como eventos que convivem, mas essa convivência jamais será pacifica, e nunca será plenamente solucionada.

O modo como Van Gogh pintou todo o caos instalado, o modo como ele organizou os campos de cores, pode mostrar uma vontade de organizar, controlar, resistir à degeneração. Como escreveu Shapiro, "é verdade que para Van Gogh a pintura era um ato de alta inteligência que lhe permitia adiar o colapso iminente"111. Ou seja, a pintura não era a conseqüência da loucura, mas um modo de manter a sanidade. Van Gogh usou o preto como uma cor que, ao contrastar com as outras cores do quadro, tem força expressiva. 
Fig.9

Carroça com boi branco e vermelho(1884)

Óleo sobre tela sobre painel 57 × 82,5
Fig. 12

Van Gogh

Natureza morta com prato vasos e flores(1884-

1885)

Óleo sobre Tela $51 \times 45 \mathrm{~cm}$

Museu de Arte de São Paulo-MASP

Fig. 10

Van Gogh

Natureza Morta com três ninhos de

pássaros. (1885)

Óleo sobre tela $33 \times 42 \mathrm{~cm}$

Rijksmuseum Kröller-Müller Otterlo

Fig. 11

Van Gogh

Natureza morta com quatro garrafas

de pedra, Frasco e tigela branca

(1884)

Óleo sobre tela $33 \times 41 \mathrm{~cm}$

Rijksmuseum Kröller-Müller Otterlo

Fig. 13

Van Gogh

Retrato de uma mulher com fita vermelha (1885)

Óleo sobre tela $60 \times 50 \mathrm{~cm}$ 
Fig. 14

Van Gogh

O jardim do manicômio em Saint-Rémy (1889)

Óleo sobre tela $95 \times 75,5 \mathrm{~cm}$

Rijksmuseum Kröller-Müller Otterlo
Fig. 15

Van Gogh

Ciprestes (1899)

Óleo sobre tela $93,3 \times 74 \mathrm{~cm}$

Metropolitam Museum, Nova Iorque

Fig.16

Van Gogh

Campo de trigo com

Corvos(1890)

Óleo sobre tela $50,5 \times 103 \mathrm{~cm}$

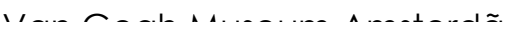




\section{Preto como superfície.}

"O preto cria um diferencial nas cores. Pulsa de uma luz além da luz, de um clima que permite uma renovação, uma fonte (...) Mas o preto é ao mesmo tempo uma noção abstrata, e também perigoso à medida que se amplia - e torna-se concreto. O preto concreto ( se ouso dizer) pode ser queimadura ou carícia, salpicadura de lama. A sua presença põe a pintura toda a construir com cores, como conseqüência do embate, uma síntese de luz e de espaço (as cores sendo aquelas sobre a tela e não dentro do tubo) ${ }^{112}$ 》.

Jacques Kober, in "Le Noir est une couleur" Derrière le miroir

"Le Noir est une couleur" (O preto é uma cor) foi o título de uma exposição realizada, na galerie Maeght, em Paris, e do primeiro número da revista francesa Derrière le miroir, em dezembro de 1946 que a acompanhou. Henri Matisse participou da exposição e deu uma declaração à revista que até hoje é utilizada como parâmetro por quem defende o uso do preto como uma cor autônoma. Seu texto contém pistas importantes sobre as razões e o modo como ele transformou em fonte luminosa o que antes era renegado às sombras.

Matisse nos revelou que quando não sabia que cor usar, lançava mão do preto. Em suas palavras: "preto é uma força: jogo meu lastro no preto para simplificar a construção. Agora deixo os pretos." ${ }^{113}$ Aqui residem dois dos pontos principais que nortearam a obra do pintor: "a serenidade pela 
simplificação das idéias e da plástica"114 e a construção da tela pela organização dos campos cromáticos.

Matisse explicou que: "como toda a evolução, a do preto na pintura se fez aos solavancos". Ainda afirmou que, a partir do final do séc. XIX, identifica-se uma recuperação e liberação progressiva dessa cor. E, portanto, o preto passou a ter "uma participação cada vez maior na orquestração colorida, comparável à do contrabaixo que chegou a fazer solos." ${ }^{\text {115 }}$ Matisse pintava como um sucessor da grande tradição da pintura, buscava no passado parâmetros para criar uma nova arte. Cita, em seu texto na revista, que utilizar o preto como cor não era uma novidade. Afinal, as gravuras japonesas mostram como os orientais já usavam o preto como uma cor qualquer: aplicavam-no do mesmo modo que o azul, ou o vermelho, ou o amarelo. Essa afirmativa remete a uma explicação dada pelo gravurista japonês Hokusai, em seu livro sobre o uso das cores, no final do séc. XIX:

"Tem um preto que é velho e um preto que é fresco. Preto brilhante e preto opaco, preto na luz solar, preto à sombra. Para o preto velho deve-se usar uma mistura com azul, para o preto opaco uma mistura com o branco, para o preto brilhante deve-se adicionar cola. Preto sob a luz do sol deve ter reflexos cinzas"116

Além disso, Matisse citou Manet como uma fonte de influência, ao referenciar o preto que surge límpido e resplandecente no casaco de veludo no retrato de Zacharie Astrud. Pede que comprovemos, também, que ele alcança em seu painel dos Marroquinos, "um grande preto, tão luminoso quanto as outras cores do quadro". ${ }^{117}$

O uso do preto pelo artista foi motivo de conjecturas, várias hipóteses foram traçadas. O historiador John Gage, num texto intitulado Matisse's Black 
Light $^{18}$, tem por hipótese que a transformação do preto em luz nos seus quadros pode ser oriunda de uma reflexão sobre a teorização do cientista francês Charles Lê Bon sobre a luz preta, do final do séc XIX. Teoria pautada no resultado de uma série de experimentos que indicava para a existência de uma luz preta ou invisível supostamente emitida pelos corpos. Assim como a descoberta dos raios $\mathrm{X}$ que, apesar de invisíveis, eram capazes de atravessar os corpos, e registrar em uma película os obstáculos sólidos encontrados, Le Bon supôs que os corpos emitissem uma luz própria que, mesmo invisíveis para os olhos, poderiam ser captados por câmaras fotográficas. Gage pautado em fragmentos nos quais o pintor aponta para uma vontade de racionalização das relações cromáticas, e em indícios dessas teorias científicas terem sido muito debatidas no início do século XX - afirma que Matisse pode ter se inspirado no conceito da luz preta para criar suas superfícies pictóricas nas quais o preto funciona como claridade.

Poucas são as evidências que sustentam a hipótese de Gage: tanto a obra quanto diversas das declarações do artista não corroboram com sugestão de uma relação com especulações científicas. Matisse afirmou trabalhar sem teoria, pois ele só conhecia a idéia à medida que se desenvolvia pela execução do quadro. ${ }^{119}$ Isso não implica uma falta de informação, mas sim num contínuo processo de desenvolvimento artístico. O pintor, no início da carreira, impressionou-se por formulações de simplificação das formas, pela divisão das cores, defendidas, entre outros, por Seurat: "finalmente a pintura fora conduzida a uma fórmula científica; rompia-se com o empirismo anterior". ${ }^{120}$ Mas, por mais extraordinário que aparentasse ser, esse método, segundo Matisse, não Ihe convinha, pois a aderência exagerada a "regras estritamente 
lógicas" funcionava como algemas e impedia a livre criação. Além disso, o resultado plástico da aplicação dessas normas era, para pintor, decepcionante. Ao, tentar fazer uma paisagem por manchas, partindo da luz branca, sombreava a pintura e "não conseguia fazer outra coisa além de matar todas as (suas) cores" O que ele almejava era criar um conjunto no qual todas as cores "cantassem, sem levar em conta nenhuma regra ou interdição"121. Ao contrário, formulações científicas não lhe interessavam. ${ }^{122}$

Sua trajetória mostra que ele buscava um saber adquirido pela experimentação da matéria pictórica e pela observação de questões da arte. "A cor contribui para exprimir a luz, não o fenômeno físico, mas a única luz que realmente existe, a do cérebro do artista" ${ }^{\text {"123 }}$, disse Matisse. Há referência ao racional, mas não a um raciocínio puro, destacado do sensível e alheio à matéria. O pensamento forjado com trabalho praticado por anos sem interrupção, alimentado por estudos e experiências, permitiu criar "uma pintura para a qual a palavra "calculada' não é o termo adequado"124. Um trabalho que exige aprendizado e preparação. Certa vez o pintor declarou que "somente após anos de preparo tem o jovem artista o direito de tocar nas cores - não nas cores como meio de descrição, mas como meio de expressão íntima."125 Um trabalho intenso para o qual "não existem regras a serem estabelecidas, e menos ainda receitas práticas; caso contrário seria uma arte industrial." Um fazer, que não se restringe ao questionamento puro, para ele o que importava "não é tanto perguntar-se aonde se vai". Mas, dar uma forma a esse pensamento e sentimento, "sobretudo procurar viver com a matéria, compenetrar-se de todas as suas possibilidades". Para ele o conhecimento técnico era imprescindível e útil, mas não suficiente. "A contribuição pessoal do 
artista consiste sempre na maneira como ele cria sua matéria e, mais ainda, na qualidade de suas relações"126, afirmou.

Alguns críticos associam a inclusão do preto na paleta de Matisse com a eclosão da primeira Guerra Mundial ${ }^{127}$. O escurecimento seria uma espécie de representação das dúvidas, do medo provocado pela destruição, dos toques de recolher que apagavam as luzes das cidades. $O$ preto apontava para uma situação. E segundo Louis Aragon, era "para a guerra, era ainda para o acontecimento que transformaria na escuridão a vida dos homens e das mulheres invisíveis, o futuro negro, o silêncio habitado no futuro" ${ }^{128}$

Pensar a inclusão do preto exclusivamente como uma reação de Matisse aos horrores da I Grande Guerra não condiz com a motivação do artista. Ele negou a possível influência dessa situação sobre a pintura. "Para os que podiam trabalhar houve apenas a restrição dos meios, ao passo que os que não podiam acabaram acumulando desejos que só puderam satisfazer com o retorno da paz"129, afirmou. É verdade que ele testemunhou sobre a angústia de estar na retaguarda e não no front, sobre a gravidade da guerra, sobre a dificuldade em se dedicar a projetos longos. Mas, também, relatou o modo como se debruçar sobre a natureza devolveu-lhe a calma, e como o envolvimento com o trabalho permitiu-lhe "abstrair do momento"130. Matisse afirmou desacreditar numa arte que servisse de propaganda, em qualquer arte panfletária, "os acontecimentos políticos são temporários, eles passam. A arte vive uma vida eterna." ${ }^{131}$ disse. A cor para Matisse não tem função narrativa, ela não simboliza nem representa. Simplesmente é cor e, usada como um acorde numa composição, pulsa em conjunto com as outras. 
O preto de Matisse difere do preto-ausência-de-cor da Guernica de Picasso que, usado em função da forma, é protesto contra a violência. O preto em Matisse não é acromático, não é luto, não é tristeza. Pelo contrário, é cor e existência de luz, é vida e alegria. Matisse une a luz e o preto. Matisse transforma em similares os elementos antagônicos (luz e escuridão) que, segundo Goethe, provocam dois estados inteiramente opostos no olho: a luz intensa ofusca, pois o olho se encontra "em extrema tensão e insensibilidade"; a escuridão põe o olho num estado mais relaxado de máxima distensão e sensibilidade, mais apto a enxergar. ${ }^{132}$

Françoise Gillot, pintora e companheira de Picasso entre 1946 e 1954, também teceu suas hipóteses. Impressionou-a o ambiente sombrio da casa de Matisse em Vence. Ao hall escuro, revelado com a abertura da porta de entrada, encadeava-se uma série de ambientes imersos numa penumbra, resultado do fechamento das janelas, portas e venezianas. Intrigou-se principalmente com a possível relação entre o ambiente sombrio dessa casa e a escolha cromática do pintor.

"Seria possível o pintor que sobrepunha cores tão vivas, que aparentemente havia banido o contrate ente a luz e a sombra nos quadros e substituído os mesmos pela interação de diversos conjuntos de cores complementares, conseguia gostar de janelas fechadas em casa, deixando o sol entrar em áreas restritas?"133

Em suas divagações, Gillot cogitou que o preto pudesse ter entrado na paleta de Matisse justamente pela escuridão que o cercava $^{134}$. Obscuridade que aguça a percepção, pois faz com que os sentidos estejam vigilantes, e tão sensíveis que menor claridade deflagra visão dos objetos que parecem brilhar. Mas, ainda segundo ela, a resposta foi-Ihe dada quando Claude Duthuit, neto do pintor, Ihe contou que o avô, por volta dos quarenta anos de idade, pensou que ficaria cego, pois sofrera de uma diminuição drástica da acuidade visual. 
Perante a cegueira iminente, ele teve duas reações, que manteve mesmo após a eliminação do risco: reduzir a exposição do olho à claridade, para que a vista descansasse num ambiente escurecido, e voltar a aprender violino para aplacar a alma. A inserção da cor preta nos quadros, segundo Françoise, poderia ser um modo de o pintor enfrentar seu próprio drama de não saber se veria a luz novamente. Se não for verdadeira, é uma hipótese que pode ser levada em consideração. Não pelo drama da cegueira, mas pela ampliação da visão do artista submetida à penumbra. Sua visão estava mais alerta. Matisse não associava o preto ao silêncio, mas ao solo de um contrabaixo. A obra de Matisse está engajada com o efeito que a presença dos objetos pintados causa no espectador, a sensação que o conjunto provoca. A penumbra, nesse caso, faz com que os objetos físicos vibrem como cordas. O preto nos quadros passa a ser a luz que tenciona os planos. A introdução dos pretos, dos brancos e dos cinzas deflagrou o fulgor das outras cores. A paleta ganhou um novo peso e, simultaneamente, tornou-se mais suave, vaporosa, leve e lânguida. A justaposição entre as cores prismáticas e as não-prismáticas fez, de algum modo, com que as primeiras ficassem mais peroladas e acetinadas e as segundas passassem a agir como cores prismáticas.

O crítico norte-americano Clemente Greenberg também teceu uma hipótese. Para ele, num momento em que houve um escurecimento geral das paletas dos franceses de vanguarda de então, a reação do pintor ao cubismo foi uma das razões para o preto ter passado, ou voltado, a fazer parte de sua paleta, após $1914^{135}$. O franqueamento do desenho, a introdução de cores além das prismáticas são, segundo o crítico, evidências claras da participação de questões cubistas no vocabulário pictórico de Matisse. Greenberg se referia 
às mudanças que ocorreram em relação ao sombreado, antes presentes nos pequenos cubos que fragmentavam os objetos cubistas, para dar uma aparência escultural com o uso de meios pictóricos, que se modificaram em sombras ambíguas na colagem. Apontava, também para a configuração das sombras que, pintadas de um preto, "cor tão sonora e pura quanto qualquer outra cor do espectro", por Juan Gris em 1915 a 1918, eram mais incisivas que as figuras que deveriam sombrear. ${ }^{136}$ Ao levarmos em conta que Matisse aproximou-se de Gris em Collioure e ambos tinhas intensas discussões sobre pintura, as questões colocadas pelo espanhol podem ter afetado o francês.

Matisse olhou para o que os outros pintores estavam fazendo. Deparouse com as investigações da superfície postas pelo cubismo, com resposta que davam a "um impressionismo em dissolução". Viu o modo que seus contemporâneos lidaram com o espaço, mas o descartou. "Os cubistas obrigavam a imaginação do espectador a aceitar um espaço rigorosamente definido entre cada objeto. De outro ponto de vista, o cubismo é uma espécie de realismo descritivo" ${ }^{\prime 137}$ afirmou. Mais uma vez, Matisse foi influenciado pela proposição do problema e não pela apresentação da solução.

Matisse analisou tudo isso. Mas observou, também, atentamente a pintura anterior à sua, ele acreditava que a arte ocorria por meio de encadeamentos, influências e heranças. Certa vez, afirmou que "seria um engano pensar que houve uma ruptura na continuidade do desenvolvimento artístico desde o começo da pintura até os pintores contemporâneos"138. Há bifurcações, tropeços, alterações e a partir do momento em que pretende um rompimento de um cânone anterior, esse, justamente ao ser negado, passa a ser a origem da ruptura. 
"O pintor, se for sensível, não pode dispensar a contribuição da geração anterior, pois ela está dentro dele quer queira ou não. No entanto ele deve se desprender dela para poder oferecer, por sua vez, uma coisa nova de inspiração fresca. (...)

Um jovem pintor deve saber que não precisa inventar tudo de novo, deve, sobretudo, organizar a sua mente, conciliando os diferentes pontos de vista das belas obras que o impressionam e, paralelamente, perquirindo a natureza." ${ }^{139}$

Matisse declarou que "todos os artistas trazem a marca de sua época, mas os grandes artistas são aqueles em que ela se imprimiu mais profundamente." ${ }^{\prime 10}$ Portanto, preferia Manet e Renoir a Rafael e Tiziano, por compreender-Ihes a natureza. Compartilhava de "suas opiniões, seus sentimentos e até seus erros". ${ }^{141} \mathrm{~A}$ arte, dessa forma, dialoga com a arte criada por outros, assim como é forjada pela situação do próprio artista. Nenhum criador está isolado num vácuo, imune às interferências.

A gênese do emprego do preto autônomo pode estar em algumas de suas telas pintadas entre 1914 e 1915, que flertam com o cubismo. Período de intensa experimentação motivado, talvez, pelas "conversas acaloradas sobre pintura"142 entre Matisse e Gris. Como, por exemplo, Cabeça Branca e Rosa (1914)(fig.17) e Peixes vermelhos e Paleta (1914-1915)(fig.18). Ambas telas foram trabalhadas e retrabalhadas por Matisse, que num primeiro momento as tinha feito de forma bem realista. Mas, ao impor progressivamente a geometria plana, ele estilizou as figuras num recorte procustiano, como se quisesse encaixá-las forçosamente nos retângulos e triângulos.

Cabeça Branca e Rosa, retrato de Marguerite, filha do pintor, começou como um rosto bem realista ${ }^{143}$. Terminou simplificado num encadeamento de faixas verticais nas cores: azul, rosa, um branco amarelado e preto. Alfred Barr escreveu que o quadro foi "o primeiro e o menos bem sucedido dos 
experimentos cubistas" de Matisse, que o quadro "tem um colorido com certo charme, mas parece essencialmente superficial se comparado com as boas cabeças cubistas de Braque ou Picasso"144. Se mudarmos o sentido da palavra "superficial" usada por Barr, se não a utilizarmos com a acepção de leviano, mas sim adotarmos o significado relacionado ao pouco profundo, sem volume, estaremos justamente realçando uma das características da solução matissiana. Nota-se a construção da figura por formas geométricas, mas diferentemente da fragmentação do modelo em pequenos cubos (palavra que traz implícita a terceira dimensão), aqui temos retângulos e triângulos, figuras planares. Para a ilusão escultórica do cubismo analítico, Matisse responde com superfícies coloridas. Uma malha de linhas pretas corta e forma o rosto. Se por um lado prende e fixa a parte central do rosto na composição. Por outro, ao tangenciar os perímetros do quadro, expande o topo da cabeça para além dos limites da moldura. Na parte da blusa, os triângulos também rompem as delimitações físicas. A grade que forma tanto a cabeça quanto a blusa circunscreve o rosto e ao mesmo tempo estende a figura. $\mathrm{O}$ retrato invade $\mathrm{O}$ espaço da parede, amplia-se.

Há uma faixa vertical preta sobre o nariz, que por ter a mesma cor e massa pictórica do fundo retira qualquer ilusão de espessura no rosto. O busto, aqui, surge engastado e coincidente com o plano da pintura. Mesclado ao fundo, não se aparta, pois, a lógica de construção não diferencia figura e fundo. Esse preto pode ser a "sombra fossilizada" de um nariz que, nesse caso, por coincidir com a forma a ser sombreada, a substitui. Sente-se o eco do problema da sombra, exposto no texto de Greenberg. 
Nota-se também ao menos uma referência histórica: a pintura dialoga com o quadro Berthe Morisot e o buquê de violetas(fig.8) de. Manet, no qual a matéria negra do chapéu e da blusa contrasta com a iluminação do rosto e do fundo, divididos verticalmente em áreas de tonalidades diferentes. Matisse trabalha com inversões. A cabeça de Berthe está levemente virada para a direita, a de Margherite para a esquerda. O negro da roupa e do chapéu no quadro de Manet desloca-se, no retrato pintado por Matisse, para a área preta que ladeia o rosto, para uma fita no pescoço e para uma faixa sobre o nariz. No entanto, as faixas verticais de luminosidade difusa violeta-azuladas do fundo, do primeiro, transformam-se em listras azuis na roupa, do segundo. O rosto de Berthe está dividido em uma área vertical clara e outra escura. Matisse acentua a divisão do rosto de Marguerite ao pintar o nariz como uma faixa preta, porém não é uma divisão entre luz e sombra, mas cromática. O preto cria tensão entre o rosa e o creme, e engasta a figura ao fundo. Dessa forma, impede que qualquer das partes salte para fora do plano do quadro. A faixa preta no pescoço de Margherite lembra a faixa de veludo do pescoço da Olympia de Manet.

"Manet é mais forte que todos nós, ele fez luz com o preto", ${ }^{145}$ essa frase dita por Pissarro, no início da trajetória de Matisse, repercutiu na obra mais madura do pintor. Nesse quadro, Matisse tentou aplicar o uso inovador e radical do preto de Manet. Pintor capaz de orquestrar grandes áreas de preto com áreas cor de rosa, cores que passavam a realçar-se mutuamente. Alterou, porém, o caráter matérico da pintura do antecessor, fez uma pintura mais lavada. Matisse deitou camadas finas de tinta que deixavam entrever as sobreposições e permitiam que a base respirasse, e às vezes aparecesse. 
Peixes vermelhos e paleta, inicialmente, retratava o pintor em seu ateliê. Porém, seu auto-retrato foi tão estilizado que desapareceu na tela finalizada. Transformou-se em um conjunto de planos brancos, rosas e pretos encadeados, no mesmo esquema cromático usado em Cabeça Branca e Rosa. Porém, restou uma forma fálica sobre um retângulo branco, ou seja, um polegar sobre o que era a paleta. Matisse enviou um primeiro esboço desse quadro num cartão postal a um amigo. Relatou-lhe por carta, tempos depois, o desenvolvimento do trabalho. Segundo ele, a composição estava mais firme, e tinha paralelos com o processo de Seurat, cuja criação se pautava na justaposição de objetos e não pela criação da mente ou dos sentimentos. Como resultado criava-se "um efeito de positivismo, uma estabilidade relativamente inerte vinda da composição." ${ }^{146}$ Matisse sempre pintava baseando-se em um modelo. O local de referência desse quadro parece ser 0 mesmo que foi utilizado no Interior com peixes dourados (1914)(fig.19), visto de outro ângulo. Uma das características marcantes dessa segunda obra é a transição entre o interior e o exterior. O olhar percorre a tela como um ambiente único, passa pelas paredes, por um sofá, pelo aquário, pela vista de um trecho de Quai Saint Michel, pela parede, por uma mesa. Integra-se, dessa forma, o particular ao público, num único ambiente todo banhado por uma luz azulada. O jogo de transparências da sobreposição do aquário à janela é um dos fatores que contribuem para a união. A continuidade entre a linha que começa como uma folhagem num copo e termina como mureta da ponte é um outro elemento de coesão. Em Peixes vermelhos e paleta, a ambigüidade entre os espaços aumenta. A união entre o exterior e o interior é dada pela interposição de uma faixa escura, um preto com nuanças azuis. Essa tela é, parafraseando Matisse, 
"um pouco direta, um pouco Manet"147. Não obstante ter levado um período longo para ser executada, transparece um ar de instantaneidade de fatura. $O$ emprego de pretos cria uma visibilidade tensa - um jogo provocado pela dualidade espacial existente entre uma aspiração à profundidade ilusória e a materialidade da superfície pictórica. A faixa preta-azulada que corta a tela na vertical, um pouco à esquerda, é um estratagema para criar um espaço dúbio para o aquário. Distingue-se um conjunto de espectros, há pernas da mesa, há um contorno do aquário. Poderíamos interpretar o aquário como se flutuasse sobre a faixa preta, como se estivesse sustentado por ela ou, ainda, como se estivesse para dentro de um buraco escuro, o aquário pode estar na sala ou fora, quem sabe, na Quai Saint Michel. Os outros elementos do quadro permanentemente contradizem quaisquer das impressões anteriores. $O$ aquário parece estar para dentro, ao notarmos uma linha que sai do campo da mesa e invade, diagonalmente, o espaço azulado. Parece estar fora, se olharmos a folha verde que sai do aquário. Por outro lado, o espaço azul mais claro, que pode ser tanto o exterior da janela, quanto a parede interior. O preto pode ser luz, que cria a sombra branca, ou sombra, provocada pela luz que veio do branco. Este espaço dúbio se mantém o tempo inteiro mudando. As coisas se aproximam e se afastam do observador.

Jack Flam argumentou que Matisse filtrou a influência cubista através de Seurat ${ }^{148}$, mas foi também através da própria obra de Matisse. Essa faixa transmuta-se em Porta-Janela a Collioure. (1914) (fig.20). Além de mais extenso, é mais intenso, é dúbio. Passa a cobrir toda a parte principal do quadro, deixando, de um lado, uma banda verde, do outro, uma azul. A faixa aparta e engasta as duas cores das laterais. Ao observarmos bem, há um 
pentimento de um gradil, sob a massa escura. Podemos pressentir para dentro do escuro nuanças verdes, azuis, que transpiram sem serem completamente vistas. Essa área cria um espaço preto colorido, ou verde azulado pretejado. $\mathrm{O}$ olhar tenta penetrá-lo, mas a superfície é rasa. ${ }^{149}$ Mas por outro lado serve de barreira que conserva a superfície bidimensional. Cria tensão entre as cores e mantém toda a figura no mesmo plano. A janela pode abrir-se para um espaço de mistério ou barrar a passagem. Diferentemente de todas as janelas escancaradas para um exterior ou interior identificável, a abertura, aqui, é feita para um espaço profundamente encoberto. Cria um sentido de ausência. Recusa-se a representar aquilo que geralmente é o tema. Percebemos que a tinta preta não somente revelou o escuro como também ocultou algo. Essa tela bebe na fonte de Manet, impossível não conectá-la com $O$ balcão. $O$ esquema de cores, a relação dimensional da tela, um centro velado, relacionam uma e outra obras. Ambas têm, nas entrelinhas, o assunto pintura, que na antigüidade era comparada a um espelho ou uma janela aberta e transparente, e na modernidade tornou-se campo opaco e autônomo.

A porta-janela teve leituras da ordem da narrativa: "um romance que começa e cujo autor ignora tudo ainda como desta vida, da casa da escuridão, os seus habitantes, a memória deles, os sonhos...", como escreveu $\operatorname{Aragon}^{150}$. Mas inspirou uma legião de pintores por suas questões de abstração formal: consiste basicamente de faixas verticais de larguras diversas, que variam de uma linha a um retângulo amplo, sobre uma faixa horizontal. O pintor norte americano Ad Reinhardt, por exemplo, considerou-a "um dos mais importantes eventos artísticos de 1914"151 Uma e outra leituras, geralmente antagônicas, 
não se anulam. A porta-janela, independentemente de estar fechada ou não, é uma obra aberta.

Esses são exemplos de como Matisse não sucumbiu às influências, digeriu-as e soube dominá-las. Afinal, "a personalidade do artista se afirma pelas lutas que enfrenta. Seria muita tolice não olhar em que direção os outros trabalham."152 Matisse foi influenciado pelo modo como Manet posicionou-se perante o fato de a pintura moderna não ser mais um sinônimo da visão, de ter deixado de ser uma questão de retratar a realidade, para tornar-se o ato de um pensamento. Matisse resolveu o mote de Manet - de manter e reforçar, com a especificidade da linguagem pictórica, a distinção entre o modelo e a tela: a pintura, apesar de ser inseparável, é incompatível com a natureza - em termos cromáticos. Isto é, ao combinar cores que não têm relação alguma com o objeto que está sendo representado, criou um efeito visual que imprime um sentimento, sensação ou humor, na mente do observador. Essa solução autoral, mais uma vez, reforça a arbitrariedade própria dos códigos da pintura. Numa conversa com Picasso, na qual ambos assumiam a importância vital de Manet como fonte de inspiração, disse:

"Manet desvinculou a pintura pura do tema e é por isso que somos os herdeiros dele. Seus temas têm uma presença abstrata, uma propriedade onírica. Têm uma sensualidade pós-baudelairiana, não diretamente evocativa. Ele aplanava as formas, reduzia as sombras ao contorno linear que acompanha o molde e, o que é mais importante, conhecia a importância do preto como cor. O impressionista puro Pissarro admitia que Manet era mais forte que todos eles porque conseguia formar luz com preto."

Matisse apontou o modo como Manet, ao evitar criar ilusão de volume pela modelação com tons de cinzas, não camuflava o preto entre tons neutros, mas, pelo contrário, usava-o como cor autônoma, plena e vívida. Mas também viu como os cubistas lidavam com as questões relacionadas entre a planura 
física da superfície pictórica e a representação ilusória de outro espaço, e como Gris transformou o antigo sombreado em uma potência cromática.

A tinta preta tornou-se campo vibrante, em muitos outros quadros, inclusive em As Colocíntidas (1916) (fig.21), Os Marroquinos (1916) (fig.22) e Banhistas no Rio (1916), (fig.23). "Meu painel dos Marroquinos não tem um grande preto, tão luminoso quanto as outras cores do quadro?"154, disse Matisse. Há alguns fatores que colaboram para isso. Muito se deve à pincelada de Matisse, que faz com que a superfície respire, tenha vida. A luz vem de trás da camada de tinta, se expande na superfície e vibra. Além disso, as tensões cromáticas realçam e fazem soar cada um dos elementos coloridos. Cada uma das cores tem uma importância vital na área e na quantidade usada. Mas pode desempenhar um papel diferente do comumente convencionado, ou seja, o branco pode ser sombra, assim como o preto pode se transformar em claridade. Por isso, em várias obras surge um preto anômalo, pois decididamente não é nem oriundo de nem análogo à obscuridade, mas, pelo contrario, é o anômalo por parecer emitir uma luz sutil e incisiva que se une tensamente às outras cores do plano. Os pretos brandem, mas trabalham no plano. Por isso o tão luminoso preto no pequeno triângulo, pintado abaixo à direita na Natureza Morta (1941)(fig.24), da coleção do MAC- USP, surgiu no espaço concebido pelas manchas de cores fortes e opacas que se contrastam e se exaltam.

As composições de Matisse têm uma força centrífuga, que impedem a ancoragem do olhar num ponto único. Têm um caráter expansivo, escapam dos limites físicos da moldura, vazam a tela para o espaço circunvizinho. 0 espectador tenta isolar e observar cada uma das partes em vão, pois continua 
querendo perceber a composição como um bloco único, que se expande. $O$ espaço é flutuante e movediço, não pode ter furos, o olhar deve estar livre para percorrê-lo, "É impossível considerar um motivo central como qualquer coisa diferente da poeira cósmica que sobra após uma explosão galáctica”"155, como escreveu o crítico Yve-Alan Bois.

Em algumas telas, porém, o preto - ou por ter sido sobreposto a alguma cor do fundo que o aplacou, ou por ter sofrido a ação do tempo - chega à retina com uma intensidade menos preta. Um exemplo, além da Cabeça Branca e Rosa, é Duas Moças, de Vestido Amarelo e Vestido Xadrez (1941) (fig.25). As áreas escuras que ladeiam as moças chegam ao olhar com um tom amarronzado. Há um esboço desse quadro, no qual Matisse indicou quais cores usaria na pintura. Para essas áreas, a cor indicada é "preto sobre vermelho"156. O vermelho subjacente ao preto, nesse caso específico, em vez de realçá-lo, alterou-o.

Em outras obras, há um preto intenso, cor que apesar de ser opaca, torna-se luminosa pelas cores que Ihe foram avizinhadas. Funciona como um elemento de tensão e união de superfície entre todas as áreas do quadro, mas que não permite ao olhar aprofundar-se. Podemos citar como exemplos os guaches recortados e colados da última fase de Matisse. Mais uma vez Matisse cria um carrossel, as figuras criam vida em sua composição. Nas composições, tudo tem uma vontade de voar, de girar.

Matisse criou uma obra variada, pois jamais se fixou em uma única solução para as questões da criação sobre o plano pictórico, por mais bem sucedida que fosse. Freqüentemente questionava sua própria pintura em busca de novas respostas. Matisse refletiu, cunhou conjecturas sobre a questão, criou 
luz com suas superfícies pretas, liberou o preto das amarras da cor local. E como disse Greenberg, não deixemos que "a luta pela serenidade e às vezes a condescendência com a elegância e charme erótico"157 de suas telas nos impeçam de ver o que está na essência de sua pintura. O pintor alterou o status do preto. O que é considerado cientificamente uma característica dos corpos que absorvem toda a luz, e não refletem nenhum raio do espectro visível; ao ponto de não permitir que surja cor alguma, a não ser trevas; em seus quadros, tornou-se cor potente, acende como luz e brilha. Matisse aplicou o preto como cor de uma maneira mais arquitetural que noturna, mais vibrante que taciturna, mais alegre que lúgubre, mais luminosa que escura, mais alegre que triste. 
Fig. 17

Cabeça Branca e Rosa (1914) Óleo sobre tela 75x47 cm Museu Nacional de Arte Moderna Centre Georges Pompidou, Paris

Fig. 18

Peixes vermelhos e Paleta (1914-1915)

Óleo sobre tela $146,5 \times 112,4 \mathrm{~cm}$ Museu de Arte Moderna de Nova lorque
Fig. 19

Interior com peixes dourados (1914)

Óleo sobre tela

Museu Nacional de Arte Moderna

Centre Georges Pompidou, Paris

Fig.20

Porta-Janela a Collioure.

(1914)

Óleo sobre tela 116.5 × $88 \mathrm{~cm}$ 
Fig. 21

As Colocíntidas(1916)

Óleo sobre tela $65 \times 81 \mathrm{~cm}$

Museu de Arte Moderna de Nova Iorque
Fig.22

Os Marroquinos (1916)

Óleo sobre tela $181 \times 280 \mathrm{~cm}$

Museu de Arte Moderna de Nova Iorque

\section{Fig.23}

Banhistas no Rio (1916)

Óleo sobre tela $262 \times 391,4 \mathrm{~cm}$

Instituto de Arte de Chicago
Fig.24

Natureza Morta (1941)

Óleo sobre tela

Museu de Arte

Contemporânea, USP, São

Paulo 
Fig. 25

Duas Moças, de Vestido Amarelo e Vestido Xadrez (1941)

Óleo sobre tela

Museu Nacional de Arte Moderna

Centre Georges Pompidou, Paris 


\section{O corpo do preto.}

"O preto, para mim, é uma cor. Não um suporte onde coloco uma cor. Ele existe cromaticamente. Ocorre que a tela deve alcançar uma densidade emocional. Para mim um quadro existe quando a gente não observa apenas aquilo que Ihe fica à flor da pele, aquilo que se acha bonito à primeira vista, mas sim o elemento que, quanto mais se convive com ele, mais vai sendo descoberto, maior densidade vai alcançando."

$$
\text { Iberê Camargo }{ }^{158} \text {. }
$$

O preto surgiu timidamente nas paisagens de Iberê Camargo, na década de 1940. Em algumas dessas pequenas telas, insinuavam-se os traços que estariam presentes, como característica particular na sua obra madura. A pintura que se afirmava como matéria pictórica densa e o arroubo expressivo que se revelava de "uma forma ingenuamente selvagem, prenunciavam um estilo existencial de arte (...) que faz da pintura um encontro e um conflito entre o eu e as forças da natureza"159 e impregnariam de drama suas telas posteriores.

Por exemplo, em Jaquari (1941), os pretos são usados para alterar o valor de outras cores. O preto não está puro, está composto. Há pretos esverdeados, pretos avermelhados, pretos azulados, pretos amarronzados. A vegetação arredia, num emaranhado turbulento de galhos, parece ter sido serrada. Sua imagem está rebatida num meio escuro tão viscoso que pode ser tanto reflexo n'água, nesse riacho de águas turvas, nesse "espelho baço", ${ }^{160}$ quanto vegetação caída, transformando-se em húmus ${ }^{161}$. É uma teia, uma paisagem 
inóspita formada por "árvores desgalhadas surradas pelo vento"162. A paisagem do Rio Grande do Sul foi muito importante para lberê, as margens do rio Jaquari, o mato e a sanga apresentaram-se como gênese de uma poética que se desenvolveria desgarrando-se da origem, pois "Iberê não foi um paisagista"163. Esse local da infância transformou-se em imagens gravadas na mente do pintor:

"Lembro-me de uma infância em que eu corria no mato, parecendo aquelas moscas douradas que ficam paradas no ar e que, como um disco voador, nos surpreendem com súbitas guinadas. Lembro-me do mato e suas teias de aranha-quase um mundo encantado..."164

O mundo encantado, o "pátio da infância", conforme lberê o denominava, foi "nada mais que o vazio onde tudo pode existir" ${ }^{165}$. Entre os êmbolos de seu processo criativo: um brinquedo, a imaterialidade de raios luminosos ou das sombras, as imagens, lembranças, elementos surgidos na infância, acompanharam-no sempre. Assim como Itararé, pequena cidade gaúcha, "cenário fumacento e inesquecível"166 da sua adolescência, pode ter eclodido como o preto fuliginoso que recobriu algumas de suas telas.

No final da década de 1940, Iberê mudou-se para o Rio de Janeiro, passou a pintar becos ensolarados do bairro da Lapa. O preto quase foi banido das paisagens urbanas cariocas. Suas telas, dessa época, eram mais claras e a pintura com tinta mais diluída, mais rala, uma influência das aulas que tivera com Guignard. Ganhou uma Bolsa e viajou para a Europa, entre 1948 e 1949, onde, em Roma, teve aulas com De Chirico e, em Paris, com Lhote.

O anseio de conhecimento guiou os passos lberê durante sua estada européia. Ele percorreu a história da arte inteira, mergulhou em diversas épocas na procura de se conscientizar da excelência da pintura. Buscou 
desvendar os artifícios peculiares utilizados por cada pintor para impetrar soluções específicas, em cada pormenor das obras. Investigou os procedimentos dos grandes mestres: as identidades na aplicação das cores, dos contrastes, das variações de valor, da cadência, enfim, dos elementos que compõem a linguagem pictórica. Fez cópias de Giotto, Goya, El Greco, Rubens, Rembrandt, Velásquez, Vermeer, Ticiano, dos desenhos Michelangelo etc. Iberê perscrutava os quadros, os detalhes, as camadas sobrepostas, as passagens de cores, "querendo virar raios-X, saber, saber tudo. E anotava no ato o que the parecia de interesse, com a humildade que os que querem saber têm de ter."167

Acreditava num aprendizado através da observação dos grandes mestres, isso não significava uma adesão à pintura acadêmica, pois, para ele, os grandes mestres jamais foram acadêmicos. Iberê afirmou que para se entender a pintura de Van Gogh, "aquela liberdade a que ele se dava no uso dos contrastes", era necessário recorrer a Rubens ${ }^{168}$. Buscava compreender a formação, a origem e o percurso que culminou na arte de então. Era como se ecoasse em sua mente a pergunta: "De onde veio essa pintura a que chamamos de moderna?" Fundamentalmente, queria apreender a "estrutura da pintura, que julgava fragilizada pela dificuldade dos modernos, de aproximar-se dos grandes pintores do Renascimento, do Barroco"169. Vale a pena lembrar que era o pós-guerra europeu. Época confusa da retomada do mercado de arte, na qual se debatiam várias formas artísticas. A abstração era questionada de várias maneiras, e surgiam propostas contraditórias quanto às suas possibilidades. Eclodiu o abstracionismo informal na França, na Itália e na Espanha, mas da Alemanha vinham propostas de racionalização geométrica. A 
Bienal de Veneza, em 1948, apresentava de um lado, a figuração de Morandi, de outro o abstracionismo praticado nos Estados Unidos. A arte passa a existir como uma categoria autônoma da expressão criativa do artista. Mas, na pintura, o quadro existia como matéria opaca: deixou de ser uma janela aberta para o mundo. Iberê escutou ecos dessas discussões, mas nesse momento, voltou-se para a grande tradição. Declarou que durante sua permanência na Europa procurou ver e aprender:

"Uma viagem ao velho mundo, raiz da nossa cultura, é sempre importante. Ver o original de uma obra é dispensar o intérprete. Não se trata de cedo ou tarde, mas o de saber ver. Milhares de pessoas desfilam pelas galerias do Louvre, olhando sem ver. (...) $O$ conhecimento enriquece, a ignorância deprime." ${ }^{170}$

Iberê acreditava que o aprendizado deveria dar-se no contato com as obras, num olhar atento. "Eu sempre tive a curiosidade de perguntar para os pintores e não para os livros. Eu não quero ler sobre Goya, quero saber como ele fez"171, revelou em uma entrevista. Em suas incursões pelos museus, lberê analisava as obras. Em pequenos cadernos, guardados por sua mulher, Dona Maria Camargo, encontram-se pistas das suas descobertas. Esboços apresentam a solução do modelado pela luz e sombra. Desenhos indicam as transições cromáticas. Anotações, feitas no calor da hora em que se dava o embate com a obra, apontam as questões que lberê percebia como importantes. Ele não analisava como os pintores copiavam a natureza, mas como era a solução pictórica, como usavam a linguagem para se exprimirem ${ }^{172}$. Ao analisar um afresco Piero della Francesca em Arezzo, não focou no modo de utilização da perspectiva linear, mas anotou que o pintor usara cores planas e claras e um modelado "muito comedido". Prestou atenção em partes que compunham o todo. Destacou uma perna, um braço, um homem apoiado em uma pá, uma cidade pintada ao fundo. Ressaltou a ausência de linhas de 
contorno. Enfatizou que o sombreado era feito, sobre uma base de uma cor plana, com pequenas pinceladas da mesma cor um pouco mais escura. Se, por um lado, encontramos algumas anotações que parecem regras ditadas por outros: o branco deve ser evitado, ou "um grande colorista sempre coloca cinzas entre as cores puras". Por outro, deparamos com um pensamento reflexivo e projetivo que impregnará toda sua obra futura. Em meio àquelas páginas, temos suas constatações de como se quebram as regras: exclamou que Giotto usava branco. Admirou-se do modo como Van Gogh, num quadro de Girassóis, realçou e acentuou a diferença cromática entre duas superfícies pintadas de amarelo (uma cádmio, outra clara), ao separá-las por um traço azul. Apontou para Franz Hals, Goya e Velásquez como antídotos contra a regra acadêmica que proibia o uso do preto. Anotou que Michelangelo usava a deformação das figuras e o contraste entre partes muito bem acabadas e outras toscas em função da expressão da angústia.

Ele também fazia cópias a óleo que não eram literais, criava obras com a liberdade de quem havia compreendido o sistema, a transição harmônica entre a luz e a sombra, a aplicação de meias-tintas e a colocação precisa dos cinza. Com suas cópias, ele não almejava a reproduzir um Ticiano, "mas aprender a ver com Ticiano". ${ }^{173} \mathrm{O}$ encontro com obras do passado o fez perceber que "arte não é à maneira de fulano ou sicrano, nem de seus seguidores, mas sim, a elaboração permanente de uma linguagem que se renova a cada época."174 Iberê observava a modelagem das formas, valorizava a meia-tinta: o elo entre a luz e a sombra. Um elo que seria construído de dentro para fora, por transparências, primeiro a colocação da sombra, que seria amainada, clareada por camadas transparentes sucessivas. O cuidado para que a transição entre 
os tons fosse extremamente tênue. A prudência da aplicação dos tons mais intensos, tanto claros, quanto escuros, somente no final. Na perseguição de suaves transições e cinzas coloridos, por algum tempo, no início dos anos 1950, já de volta ao Brasil, morando sob a luz tropical do Rio de Janeiro, Iberê expulsou o preto de seu elenco de cores.

A repugnância ao preto pode ser ilustrada por uma passagem ocorrida, em 1951, com Mário Carneiro, então estudante de arquitetura e aluno de Ubi Bava. O jovem - fazia paisagens, nas quais, assim como Matisse, usava intensamente a cor preta. Carneiro teve dois desses trabalhos recusados no Salão Nacional de Belas Artes. O veto foi dado porque lberê Camargo, membro do júri, julgou-o "muito radical com o uso do preto" que não devia ser aplicado, pois, em sua opinião, "furava" a tela. ${ }^{175}$.

Outro exemplo, a ser arrolado como testemunha dessa antipatia, tem um viés político: em 1954, num protesto contra a má qualidade das tintas nacionais e as restrições da importação das estrangeiras, Iberê encabeçou a organização de uma greve das cores:

"O Salão Preto e Branco significa nossa luta pela sobrevivência. No tocante a seus resultados, precisamos acreditar em alguma coisa, ainda que seja no absurdo. A vitória é essencial para a classe. Temos a maior bienal do mundo, o maior estádio do mundo. A realidade, como ninguém diz, é esta, e apenas esta: temos a maior miséria do mundo. Como pode ser grande um povo cujos artistas não têm sequer material para trabalhar?"176.

O movimento, devido à adesão maciça de artistas - 480 artistas assinaram o manifesto que foi enviado ministro da Educação, em abril de 1954 configurou uma das mais importantes articulações políticas relacionadas às artes plásticas do país. Os artistas clamavam que "sem tintas não haverá mais 
pintura colorida no Brasil"177, ou seja, o preto, no movimento encabeçado por Iberê, ainda não era cor.

Porém, na verdade, Iberê nunca foi muito radical com relação às cores. As certezas de um período podiam ser abandonadas em favor da expressão pictórica. Portanto, não era incomum ele se contradizer. "Iberê tinha umas frases, ele não gostava do verde, 'o verde foi um ataque de frescura de Deus', dizia ele. Assim como detestava as flores, mas de repente lberê pintava um quadro de flores e usava o verde". ${ }^{178} \mathrm{E}$ assim foi também com o preto. Afinal, anos antes, ao observar os grandes mestres nos Museus, no Louvre, lberê já havia percebido potencialidades simples da cor proscrita. A sua aplicação poderia substituir, com encanto, a modelação dos volumes feita, então, com o uso das suaves transições entre luz e a sombra:

"Por exemplo, o Velásquez, uma vez (eu tenho isso no meu caderninho) pegou uma brocha e fez uma chapada preta, assim, pronto, depois, com um pincel de filete, desenhou um contorno, e um cinza, assim, ele deu uma luz, pronto: uma galinha. Aí está uma galinha... uma galinha, sabes? E o sujeito... tanta complicação para fazer uma galinha, usar a expressão acadêmica, tanta sombrinha, tanta coisa... E aquele fez assim: pá!"179

Nos caderninhos, Iberê refere-se a vários outros pretos. Aponta para simplicidade de Velásquez, que transforma uma única pincelada em chapéu, ou galinha. Ressalta a variação dos pretos de Hals e a modo como Goya transforma essa cor em expressão.

A aversão passou, e o preto, inicialmente banido, retornou a partir dos quadros pintados com objetos em seu ateliê entre 1956 e 1958, que renunciaram à luz natural e às paisagens externas ${ }^{180}$. A pintura de objetos disponíveis ou escolhidos - cuja disposição sobre a mesa podia ser acidental ou arranjada e rearranjada deliberadamente - possui uma denominação que, 
tanto nas línguas latinas: natureza-morta, nature morte, natura morta, quanto nas línguas saxônicas: still-life, stilleben, significa vida inerte. A opção por retratar objetos corriqueiros - menores que a escala humana, destituídos de paixão e mistério, subordinados à manipulação e uso do homem - permitiu o início do processo da libertação do pintor, e conseqüente sua maturação artística. A liberdade artística propiciada por esse estilo pictórico que, "em grau maior que a paisagem ou a pintura histórica, deve sua composição ao pintor", já tinha sido apontada por Meyer Schapiro na análise sobre as maçãs de Cézanne. Além disso, conforme escreveu:

\begin{abstract}
"Muitas vezes associados a um estilo que explora paciente e minuciosamente a aparência das coisas corriqueiras - suas texturas, luzes, reflexos e sombras -, os objetos da natureza morta trazem a consciência a complexidade do fenomenal e a sutil inter-relação da percepção com o artifício da representação" ${ }^{\text {"181 }}$
\end{abstract}

Portanto, as frutas, as conchas, as jarras, os bules, os frascos claros e garrafas escuras inanimados eram as desculpas usadas por lberê para um exercício rigoroso: explorar as propriedades plásticas da tela e da composição $^{182}$. Paralelamente, ele trabalhava com os mesmos elementos, num arranjo estrito, nas gravuras em metal. Iberê dedicava-se simultaneamente às pinturas e às gravuras, desde sua volta ao Brasil. Valia-se de "ambas as técnicas com o mesmo amor, com o mesmo fim" ${ }^{183}$, ou seja, serviam para tornar visível o seu universo. Empregava a água-forte e a água-tinta, na qual experimentava o verniz mole, a maneira-negra, processo de açúcar etc. Suas gravuras possuíam características bem pictóricas, "o preto era muito bonito, muito forte, assim como o cinza. Tinha uma textura, uma intensidade"184

Iberê, gravador, possui um elo com Oswaldo Goeldi. Escreveu que o achava um artista íntegro, que permaneceu "autêntico, fiel a si mesmo, 
indiferente à crítica que largo tempo o relegou" e que "inscreveu na pele dura da madeira de fio todas as nuances de seu temperamento de artista dotado, dono de uma visão trágica e silenciosa dos homens e das coisas" ${ }^{185}$.

Goeldi foi um mestre em retratar seres solitários, que peregrinam por atmosferas noturnas, em vão, sem jamais encontrar guarida. As cenas ocorrem num tempo em suspensão, num meio pesadelar. Esses seres estão às margens da vida. São ninguém, mas simultaneamente agarram-se desesperadamente a qualquer vestígio de uma individualidade. Para eles, manter o anonimato e a marginalidade é o único meio de evitar a amalgamação, que destitui o ser de seu próprio eu. Como sobreviventes, lutam contra o que o vendaval prenuncia.

Não há céu estrelado. As noites goeldianas apresentam-se como se tudo viesse refletido das profundezas escuras de um abismo. A luz bonita, que persevera em brotar do preto, opõe-se à atmosfera tenebrosa. Duas luminosidades opostas tencionam a superfície das gravuras, se por um lado a penumbra banha completamente a cena, por outro a luz que vaza pelos sulcos sugere uma realidade ofuscante para além da superfície enegrecida. Há uma ambigüidade entre a luz no plano da representação e aquela que alude a uma possível fonte escondida sob a membrana escura. Conseguia, assim, obter contrastes apuradíssimos entre áreas pretas profundas, e rasgos brancos luminosos.

Silêncio e drama povoam, de algum modo, as gravuras de Camargo. $\mathrm{O}$ confronto entre áreas francamente claras e as que estão submersas nas trevas dá aos trabalhos um intenso tom dramático, um isolamento severo. Iberê 
abolira os meios-tons, conforme afirmou: "Realmente gosto muito do preto e branco, por causa, sobretudo, do valor, não gosto de coisas que não tenham essa estrutura que o valor dá à obra"186. A gravura, em processo análogo ao da pintura, era feita por meio de construção, sobreposição de etapas que progressivamente adensavam as tonalidades ${ }^{187}$. Em suas gravuras, os contrastes entre o preto e o branco apresentavam, com toda violência expressiva, a recusa a aderir à contingência, a resistência à dissolução.

É plausível supor que a prática da gravura tenha ajudado lberê a se reconciliar com a tinta preta a ser aplicada nas telas. Assim, as garrafas abraçaram a pretidão. Nas pinturas, Iberê laborava as cores, o jogo de valores luminosos, a relação de contraste e modulação entre os tons. Realizar uma dessas naturezas morta era um trabalho fatigante, segundo afirmou:

"alinhei uma porção de latas, garrafas, laranjas, enfim, os meus brinquedos de sempre. Trabalhei nesse quadro mais de um mês, gastei uma pequena fortuna em tintas. Mais de uma vez, voltei tarde para casa, depois de me extenuar horas a fio, em botar e tirar uma cor que não se ajustava. (...) O final dos meus quadros é sempre dramático" ${ }^{\text {188 }}$

Iberê confessou que tinha de recorrer, em vão, ao disco de cores, na tentativa de solucionar os problemas que freqüentemente o assolavam no embate com o quadro. Não bastavam os conhecimentos racionais e teóricos, ele devia lançar mão de seus instintos. Às vezes, "era um homem que, se desesperava, inutilmente, a procurar uma cor para o fundo do quadro, ou melhor, para uma pequena parte do fundo" ${ }^{\prime 189}$.

Em muitas de suas declarações lberê comentou sobre a função da cor. Certa vez, afirmou que não se interessava pela cor enquanto cor, tanto que escolhia sempre roupas cinzas, marrons ou pretas. Não gostava de ficar a contemplar um arco-íris, em suas palavras: 
"A cor me interessa quando ela se transforma em uma linguagem toda particular do pintor, uma cor, quer dizer um quadro para mim é um gris colorido. Não posso ver uma cor no quadro, quer dizer não tem cor é um quadro. Se tem uma cor que eu reconheça é porque ela está fora do lugar. É integrado naquela relação. E aí que aquilo se tornou uma linguagem: aí, quando a cor é linguagem expressiva de um sentimento do homem, me interessa. Mas se ela é cor, cor, não me interessa não". ${ }^{190}$

Uma cor isolada não significa nada. E não é somente isso, se uma cor sobressai isoladamente no quadro, ela está fora do lugar. Iberê assegurou que a cor na pintura funciona somente em relação às outras cores da composição. A cor deve se transformar numa linguagem toda particular do pintor. Em seu caso havia uma preocupação com a fusão das cores, com a fusão entre figura e fundo. Isso não significa uma transição gradual, mas uma união pela tensão, que pode ser carregada de cicatrizes.

As garrafas que dão o título a uma tela de 1957 (fig.27) alternam-se escuras, cada qual de um tom, ora com um toque esverdeado, ora com um toque avermelhado. Estão enfileiradas. Não se pode chamar de lilás ou violeta, o fundo no qual os objetos se encaixam. Vêem-se uns azuis avermelhados, que se transformam nuns rosas azulados. As camadas se sobrepõem, mas não se mestiçam, elas respiram em momentos diferentes, pulsam. Mas estão todas lá, simultaneamente.

Os quadros posteriores escurecem, ganham uma lucidez soturna, o preto resplandece nas formas delgadas perfiladas, dando um ritmo à composição. Ferreira Gullar disse que "as garrafas, de que lberê se vale num primeiro momento, são de Morandi”. ${ }^{191}$ Mas, não são somente de Morandi (fig.29), são também de Picasso (fig.28) e de Van Gogh (fig.11), pois deixam de ser garrafas para serem plasticidade pictórica. 
Assim como as de Morandi essas pinturas de Iberê não falam do objeto, mas do espaço criado dentro do quadro pela variação de seu posicionamento e de como são modificados pelas variações da luz incidente. São criadas "ainda pela interpretação pictórica e pelo estado de ânimo do pintor". ${ }^{192}$ Mas em Morandi, há uma poeira depositada uniformemente, que mescla os objetos na mesa, a mesa na parede, a parede na superfície. A combinação delicada das cores infringe a essas obras uma entonação subjetiva. Sua intenção é dúbia, confunde-nos, não sabemos se ele quis causar o brando aparecimento ou provocar a gradativa desaparição dos objetos. Em lberê, os objetos abandonam sua característica mundana para transformarem-se em campos definidos de cor, batalhas travadas na superfície. Não o esmaecimento, mas sim o conflito. Substituem a suspensão do sujeito, pelo arrebatamento.

Iberê escolhia, por matéria, as coisas humildes, pois não acreditava que a arte tivesse de referenciar a "velocidade, e toda a pressa do homem de espírito e de negócios". ${ }^{193}$ Ele acreditava que "todas as ocupações do contador e do homem comum" eram irrelevantes para a pintura, não importavam, não acrescentavam nada A contingência era, portanto, em sua opinião, completamente inconciliável com a arte. A correria e as exigências capitais da vida existiram em todas as épocas, de uma maneira mais frenética ou mais desacelerada, mas isso não seria a sua referência. A arte de cada tempo deveria equiparar-se "à vida profunda do homem", a sua conexão com o universo, ao cosmo, ou "como se queira nomear essa essência inapreensível". Para lberê, os objetos não eram o tema verdadeiro, e sim, o pretexto. Sua arte deveria utilizar o palpável para representar o intangível. Apresentar o caos 
através da organização. Extrapolar a "soleira do objetivo", transgredi-la e ir além. Iberê escreveu:

"O tempo fia, mas este nó permanece. A questão metafísica continua ocultada, mesmo que os homens furem o céu com a ponta estrepitosa de seus aviões em reação, mesmo que se arrastem pela terra somente com a ajuda de suas pobres pernas. A natureza calase, inclusive o homem que lhe pertence."194

Suas garrafas anunciavam a pintura madura se seria deflagrada pela inclusão de carretéis entre sua gama de objetos. As garrafas morandianas promoviam uma metafísica que buscava "uma cor sem reflexos nem fulgores, inerte e opaca, quase uma substância exsudada ou secretada pelas profundezas do ser, como a cera pelas abelhas" Morandi chegava a "esta identidade essencial entre o eu e o mundo, a esta escolha do objeto em termos de mediação e aplainamento, por meio de um lento processo de seleção e redução de valores"195.

Diferentemente, as garrafas escuras de Van Gogh se unem veementemente aos potes, pratos e taças, dando aos quadros um ar tectônico. Os objetos apertados mesclam-se quase a ponto de perder suas qualidades físicas e materiais, mas se mantêm ainda como objetos, não se libertaram completamente da volumetria. Eram composições com uma organização desajeitada. Há uma tensão nas coisas dispostas. As cores são sombrias, e os contrastes não encenam as batalhas travadas, pelas quais Van Gogh é reconhecido, em suas telas maduras. Estão longe de ser suas obras-primas, mas trazem incrustadas tanto a "resistência a desintegração", quanto o "apego ao objeto" ${ }^{196}$ sempre presentes em sua pintura posterior. Pois, conforme supôs Meyer Schapiro: "o objeto era símbolo e garantia de sanidade"197 para Van Gogh 
Já as obras de Picasso, aqui referidas, são as proto-cubistas, nas quais, com garrafas e potes, ele buscava revelar a essência constituinte de seu tema. Usava uma organização simples, de uma clareza quase clássica, na qual cada objeto, apesar de disposto em seu próprio espaço, subordina-se à composição. O que provoca simultaneamente a interação e o confronto entre os elementos plásticos, e estabelece o ritmo da tela. A redução do volume e a escolha das cores criam uma sensação de unidade arquitetural, os itens mesclam-se e o próprio quadro torna-se um objeto. As naturezas mortas de Picasso possuem uma paleta mais quente e são mais libidinosas que as de Iberê. Um único falo escuro e umas poucas aberturas claras alternam-se no quadro, em oposição à seriação nas telas do brasileiro.

Assim como Picasso e como Cézanne, Camargo também abdicou ao volume dado pela perspectiva linear em suas composições, aderiu ao plano. As laranjas transformaram-se em círculos, os bules tornaram-se retângulos, as garrafas metamorfosearam-se em formas graciosamente distendidas, enfileiradas em cadência. Tudo se decompôs em elementos significantes. As suas formas começaram a distanciar-se, numa aceleração constante, da visão alicerçada na realidade física do mundo. Executaram a passagem do entendimento perceptual baseado na natureza, para a compreensão da visibilidade ou modo de ver sensível geral. Nesse ponto da trajetória de lberê, a paleta escureceu e as dimensões de suas telas aumentaram. Por exemplo, num retângulo áureo de $1,50 \mathrm{~m} \times 0,53 \mathrm{~cm}$, alinhou os "seus brinquedos de sempre" ${ }^{\text {198: }}$ várias garrafas, laranjas e potes. Ele trabalhava tanto que, no final de $1957^{199}$, uma hérnia de disco da coluna - produzida pelo movimento freqüente de virar e desvirar os quadros no cavalete - foi diagnosticada. "Eu fiz 
isso muitas vezes. Lembro-me que na ocasião tive a sensação de ter ultrapassado o meu próprio tamanho" ${ }^{200}$, escreveu Iberê, ao relatar o caso.

Iberê, devido ao repouso forçado, reencontrou um objeto que seria o deflagrador de toda a sua arte posterior: o carretel: um pequeno cilindro de madeira, plástico ou papelão, com rebordos, usado para enrolar linha. Enquanto estava nas mãos do Iberê criança, no Rio Grande do Sul, era um brinquedo, um jogo. Sacado da caixa de costura da mãe, transmutava-se através da imaginação do garoto para servir às brincadeiras infantis. Já na ação do lberê pintor, dentro do ateliê, metamorfoseava-se em signo de sua pintura.

No início de 1958, os carretéis ainda surgem tímidos no meio das garrafas, fazem parte da coleção de objetos utilizados nas naturezas mortas. Os itens dispostos sobre uma mesa no ateliê reagiam à luminosidade. Iberê registrou a impressão que o movimento da luz sobre os volumes lhe causara:

"Sol do meio dia. Um pálido clarão sobre o muro defronte à janela. O peitoril se acende. Uma abrasada lâmina de luz penetra dentro da sala: corta a mesa, transpassa e recorta os objetos que the estão em cima. Eles se acendem: os caramujos gritam seus brancos. Manchas negras Ihes escapam debaixo, circundando-os. O vermelho torna-se púrpura; o amarelo, laranja;o arco-íris está sobre a mesa. As garrafas irisadas tornam-se irreais.

Não há mais peso nem dimensão, são apenas cores que flutuam no ar". ${ }^{201}$

Os carretéis eclodiram nas telas na cor-tema desse estudo, talvez por uma necessidade do desenho. "Os carretéis, esses objetos relacionados aos jogos de infância, eram afirmações muito fortes, pediam uma definição gráfica bem marcada. Ele usava o preto e muitas outras cores". ${ }^{202}$ As composições das pinturas eram replicadas nas gravuras. O carretel passa a ser o elemento predominante nas telas. Em profusão, multicoloridos, inicialmente eclipsam os 
outros objetos da mesa: uma ou outra garrafa travestida de pino, uma ou outra laranja de círculo. A volumetria foi completamente desbancada, trocada pela ambigüidade grandiosa da significação da figura. A sensação provocada pelos carretéis pretos é cambiante. Parecem ora ausência, ora presença. Fenda, mas também matéria.

Depois tornaram-se soberanos, ocupam a tela. Um mesmo elemento, de forma definida, permitiu que a linguagem pictórica alcançasse grande autonomia, a composição se organizou de modo mais preciso. Inicialmente os carretéis foram postos sobre uma mesa. Uns sobre os outros, equilibrados. Porém detém o equilíbrio instável e temporário de um castelo de cartas. A escuridão passou a envolver a tela, tons de preto surgiram.

Enquanto os carretéis guardavam alguma relação de equilíbrio, a mesa aparecia em alguns quadros, desaparecia noutros. Mas o plano, no qual os conjuntos se apoiavam, estava presente, de uma forma ou outra. Havia uma concretude, a figura não se dissolvera, mesmo quando resvalava no geométrico, como em Carretéis com três laranjas (1958) (fig.27). São agrupamentos que remetem a um arranjo de vigas "l”, material para trilhos de trem, umas recobertas de óleo e fuligem, outras de pó ferruginoso. Os carretéis pretos possuem uma aura mais clara, e são figuras de uma espacialidade ambígua, oscilam entre a profundidade e a protuberância.

Em outros quadros, à forma soma-se a cor. Em Mesa azul com carretéis (1959) (fig.28) Há um jogo de pretos-azulados sobre pretos profundos; pretos mais claros - que não chegam a chamarem-se cinza - e pretos intensos que resvalam no negro. Há poucas cores mais quentes: um vermelho mais forte, 
um siena queimado, uma sombra alaranjada, e poucas mais claras. Iberê criou uma pintura autônoma que expunha toda a materialidade da tinta e as sobreposições cromáticas. Os carretéis, ainda reconhecíveis enquanto objetos simplificados por uma geometria heterodoxa, encetavam uma queda, estavam desequilibrados. Iberê materializou uma mesa de pernas alongadas, colocou os carretéis na parte superior da tela, para que o desmoronamento fosse maior. Nas telas seguintes os carretéis iniciaram um processo de aceleração que os levaria a girar permanentemente no ar.

Em Dinâmica de Carretéis (1960) (fig.29), os elementos remetem a ampulhetas, nas quais o tempo é contado de uma maneira singular. O elo entre o passado e o presente. O pintor que, ao remexer na gaveta dos guardados, achou sua possibilidade de expressão. Ou os tempos da arte: a pintura, que conectada e herdeira de toda a tradição, resiste bravamente a sua desintegração iminente, afronta o anúncio da sua própria morte. ${ }^{203}$

Na V Bienal de São Paulo, em 1959, o tachismo europeu ${ }^{204}$ que, na opinião de lberê, "devolveu à pintura a supremacia da intuição, do sentimento. Com a aparente desorganização, destruiu a rigidez geométrica do concretismo. Foi mais um momento nesse eterno refazer a forma"205 e a abstração lírica foram ostensivamente apresentados. Tendências artísticas que, descrentes das promessas da racionalidade tecnológica, promoveram, de um lado, a reinserção do sujeito na ação que cria as obras, através da valorização do gesto, e por outro, o desmanche da forma. Alguns artistas, de tão incrédulos das possibilidades da pintura pura, aspiravam a que as obras imergissem na sujeira do mundo e se imiscuíssem à vida. ${ }^{206}$ Nas obras de lberê a expansão começava a se armar. A dimensão das telas aumenta, o carretel perde sua 
forma para ser pintado num movimento intempestivo. As pinceladas modelavam as formas, num sentido mais escultórico que pictórico. As camadas de cores - escuras, rebaixadas, mas muito diferenciadas - eram sobrepostas Uns quase-retângulos empastados surgiam engastados na matéria escura. Os carretéis, mesmo que irreconhecíveis na tela, estavam presentes como os modelos. Uma imagem e uma declaração são muito esclarecedoras, quanto ao posicionamento do pintor com a figura. Numa fotografia há o registro de um momento de pausa no trabalho: Iberê Camargo acende um cigarro, à sua frente diversos carretéis estão colocados sobre uma mesa, às suas costas, pousada no cavalete, está uma pintura da série Estrutura. A cena avigora o depoimento dado a Cecília Cotrim Martins:

"Pois é, e a pintura, a feitura de um quadro é um ato físico, quer dizer, é preciso concretizar aquilo, formar, dar forma ao modelo que me orienta. O meu ponto de partida pode ser... digamos... é o modelo, o que estou me propondo; isso é a pista do vôo, porque depois é que a gente vai decolando, vai se afastando do modelo, e vem esse mundo subjetivo e toma conta daquele presente, se mistura com aquele agora...."207

Iberê tornava os carretéis claros que estavam fisicamente dispostos sobre uma mesa, em rastros incrustados num magma escuro na tela. Uma pintura na qual, num fundo espesso e gris, surgem formas em diversos tons baixos. Há uma grande ambigüidade nessas figuras: pois, assim como podem estar prestes a voar para o espaço, podem ser totalmente engolidas pela matéria. $\mathrm{Na}$ tela Estrutura (1961) (fig. 30) o gesto surgiu desencantado. Mostra certa desilusão, revelada no compasso sem cadência das pinceladas. As camadas de cor sobrepõem, num gesto truncado, as camadas anteriores. Ensaiam uma pulsação constante, mas executam uma série de tropeços e saltos. O preto está presente e possui uma grande potência. Isoladamente é pausa, em 
conjunto é movimento. Bloqueia o pequeno vestígio vermelho submerso na massa cromática mais fria que insiste em surgir, vazando as bordas dos retângulos. Todos esses elementos manifestam-se como se o sujeito, por mais que tentasse se submeter à circunstância, fosse impelido a rompê-la. Há um incômodo evidente. A pressão aumenta, até que em um momento o preto amplia-se no espaço. As coisas, quando estão muito concentradas, possuem essa latência expansiva, na opinião de lberê:

"O movimento sempre foi uma coisa que me interessou, não faço uma coisa estática. E os carretéis, aquelas formas, se prestaram muito a esse dinamismo, uma dinâmica... e naturalmente houve uma vez um maior espaçamento, outra vez se concentraram em grupo, em núcleo, não é?

E um dia eu fui a Jaguari, fui até o cemitério onde estão sepultados meus pais, próximo da viação férrea, da estação, e naquele momento por acaso passou um trem e a máquina expeliu uma fumaça negra, cuspiu aquela fumaça negra e ela toldou o azul, que era um céu assim de dia de muito azul, puro azul, e aquela mancha encobriu o cemitério como um véu escuro, e depois foi esgarçando, o véu foi se esgarçando, foi esmaecendo, se expandindo, e sempre aquilo ali me inspirou aqueles núcleos em expansão... as coisas que se expandem, compreendes, que se expandem...."208

A pretidão revestiu a tela Estrutura dinâmica (1961) (fig.31)

Paulatinamente recobriu as telas como a noite. A escuridão fundiu-se ao tema, metamorfoseou-se em matéria pictórica, como o óleo que recobre engrenagens pretas retintas. Há quem relacione o escurecimento da paleta de Iberê com uma espécie de luto pela situação política que se esboçava no país. "Ela é o lugar da resistência e da dor, da revolta e do desejo de ação. Iberê reagindo à escuridão política, recorre ao negror cromático, à acromia"209, escreveu Icleia Borsa Cattani. Porém, a explicação não é tão cristalina e simples. A obra parece sim é questionar o que o luto esconde. ${ }^{210} \mathrm{O}$ que estaria oculto na escuridão profunda? Iberê disse que "um sujeito pode descer fundo em si mesmo, mas no fundo há sempre sombras, há mistérios que ele não pode 
desvelar". ${ }^{211}$ Um sentimento de instabilidade e angústia, de um sujeito em crise, insurge das relações instauradas no campo das pinturas e também nas gravuras do período. O espaço transpira "sua descontinuidade pelas forças que emergem do fundo das trevas, a negação a sua visibilidade positiva"212. Ao mesmo tempo esse espaço é palco de metamorfoses, relaciona-se ao subjetivo, ao pensamento criador de um indivíduo. "Dizem que cada um carrega dentro de si o seu mapa sentimental. Por isso minha pintura é beira de sanga, é cerro encantado, é brinquedo esquecido no oitão da casa e mil outras insignificâncias que trago comigo", afirmou Iberê. Insignificâncias que se transformam, seja pela brincadeira da criança, seja pelas mãos do artista, em obra da criação. Pois quando lberê "era guri, brincava de trem: corria, bufava e movia os braços para imitar as locomotivas." Pois em sua opinião: "Transformar-se nas coisas, vivê-las é criar" ${ }^{213}$. Por isso o caráter dinâmico dessas composições. O acúmulo e a sobreposição das formas trazem como contrapartida uma redução cromática drástica, que remete aos pretos e grises das "pinturas negras" de Goya.

O preto nessas telas de lberê não surge puro, é composto. Resultado da adição de outras cores: azul da Prússia adicionado ao siena queimado, ou azul cobalto misturado a terra siena, ou vermelho cádmio adicionado ao verde esmeralda, ou ocre somado ao violeta, ou todos misturados, e ainda juntandose às misturas um pouco de negro de marfim. Iberê transformava as telas em paletas, e essas superfícies tornaram-se palco no qual as cores - por um processo de adição, raspagem e amalgamação - são criadas. Iberê, em seu processo de aprendizado, havia esboçado e anotado com cuidado, em suas cadernetas, as paletas usadas por diversos mestres do passado. Entre elas, a 
paleta de retirada da mão de Velásquez, no auto-retrato do pintor, no canto do quadro As meninas, chama a atenção (fig. 26). O arranjo de cores anotado por Iberê inclui várias "cores escuras". Um X no meio da paleta indica a mescla. Podemos inferir que, nessas telas, Iberê amplia aquele pequeno detalhe da tela do espanhol. Ele metamorfoseia sua tela numa gigantesca paleta. Ele usa diversas cores simultaneamente, que são mescladas, arrastadas, puxadas, $\mathrm{O}$ processo deixa transparecer resquícios das cores em meio à massa escurecida. Rastros que provocam as sutis diferenças cromáticas. Se enfocado por esse ângulo, podemos supor que o escuro aqui se associa a um resultado aditivo, à soma de todas as cores, a um processo de transformação. Como afirmou Iberê: "O quadro que pinto é sempre a revelação de uma viagem interior. Neste mundo da alma há sombras, luxúrias, pecados, ranger de dentes de que nos fala Dante, e amor..."214 Esses seus quadros podem ser vistos, então, como uma ode ao sujeito com suas contradições, uma ode a um mundo no qual dor e prazer caminham lado a lado. Ao empregar seus tons escuros, Iberê obtém, nessas telas, uma luminosidade surpreendente. A obscuridade nesses dos quadros não é somente obscuridade: traz consigo, justamente por expor sua ausência, a luz. Uma lucidez que se revela após alguns instantes de observação, quando surge - naquilo que antes se apresentava como um monocromo - uma heterogeneidade cromática, com vários tons e nuanças. Encontramos em uma declaração de lberê a verbalização dessa aparente incongruência:

"Então, por exemplo um dia muito ensolarado, de uma maneira genérica pode ser um dia ensolarado; mas para um pintor, para uma pessoa que tem outro enfoque da vida, ele pode ser até muito sombrio, pode haver um sol muito sombrio. Embora pareça um paradoxo o que eu estou dizendo, há sombras no sol. Neste dia iluminado há, para mim, um sol negro". ${ }^{215}$ 
No meio da escuridão, os lampejos dos riscos com tinta branca acinzentada confundem-se com os brilhos dos reflexos da superfície entenebrecida. O quadro muda, conforme a luz resvala pelas marcas deixadas pelo pintor. A tela somente pode ser totalmente apreendida, quando 0 espectador abandonar sua posição de um observador estático e passivo. $\mathrm{O}$ olhar solitário não consegue mais dar conta do que ocorre no plano sobre o chassi. O corpo deve movimentar-se, para que a luz incidente na superfície, ao encontrar as saliências da matéria, revele o evento pictórico. O movimento dos olhos desvenda os relevos e permite que o olhar apalpe ${ }^{216}$ o quadro. $O$ observador participa ativamente da apreensão da pintura, a "visão depende do movimento"217 Amplia o fenômeno da visão que deixa de ser somente escópico, para abarcar o tato, a audição e o olfato ${ }^{218}$.

Em anos posteriores o preto é usado para criar matizes grises e amarronzados. A noite é trocada pela lama. Os frios azuis que antes se encontravam depositados sob os pretos foram tocados por cores progressivamente mais quentes. Surgem obras como Núcleos (1965) (fig.32) nas quais os pretos brotam como pedaços de carvão num imenso braseiro fumegante. Os vermelhos chamejantes remetem ao fogo, ao magma que borbulha no centro do planeta e explode, recobrindo a terra com a lava. $\mathrm{O}$ gesto violento expande a pintura de uma maneira visceral. As estocadas de espátula na tela poderiam ser tanto a busca desesperada de resgatar a forma soterrada sob a massa de tinta, quanto a tentativa descontrolada de trucidar essa mesma forma.

Iberê, mesmo num momento no qual diversos artistas imiscuíam a arte na vida $^{219}$, acreditava que a pintura pertencia a uma esfera própria, com sua 
linguagem e especificidade. Afirmou: "técnica para mim é resultado de cunho pessoal que o artista obtém no emprego de processos tradicionais. Sei não ser fácil fazer seu o que é de todos. Mas é exatamente isto que faz existir Rembrandt, Goya (...)". ${ }^{220}$. Coerente com a determinação de manter a fidelidade à tradição, recusou-se a trazer elementos heteróclitos para o espaço pictórico. Considerava-se herdeiro da grande pintura, uma linhagem que incluía Picasso e Matisse. Anos depois, justificou-se:

"Eu disse isso no sentido que eu descendia do modernismo, de que ninguém vem do nada. Se você não tem uma ascendência, você passa a ser um inventor e o problema da pintura não é de invenção, é de criação. É por isso que tem coisas que despertam interesse, que não tocam"221

A busca da forma requereria, portanto, a escavação da sujeira do mundo. O conto $O$ relógio ${ }^{222}$, escrito por lberê, pode ser entendido como a metáfora de uma jornada heróica em busca da pintura perdida. $\mathrm{O}$ personagem deve escarafunchar os excrementos contidos num fosso para reencontrar um relógio, jóia preciosa que foi totalmente tragado pela imundice. Relógio que voltará fragmentado, aos pedaços, alguns rubis aparecem em meio à massa escura e fétida. Para Iberê, a pintura podia ser a transformação de algo real que, deslocado da realidade, existiria enquanto forma no quadro. A arte poderia ser extraída da contingência, mas jamais se confundir com o mundo. ${ }^{223}$ Para Iberê:

"A arte permanece na sua categoria, como o mar, que apesar do fluxo e refluxo, continua no seu próprio leito. As investidas da antiarte não fazem mais que afirmá-la. Muitos são os arautos da destruição da arte e, portanto, do homem que morrerá com ela. Vaticinam também o fim da religião e do pensamento filosófico. Com o advento da bomba atômica, também apregoam o fim do mundo"224

O artista devia estar consciente do meio para conseguir expor sua subjetividade. Iberê permanecia, e sempre se manteve, fiel à tradição. Usou muita quantidade de tinta à óleo de boa qualidade, "os melhores conteúdos nos 
maiores continentes"225 para satisfazer sua volúpia de pintar com espessa massa de cor. Ao ponto da falta do preto Ihe frear todo o processo, conforme relatou:

\begin{abstract}
“...Estou de braços cruzados e na iminência de explodir por não pintar por não ter preto, a mais bela cor segundo Tintoretto. Peço em caráter de socorro urgente, para enviar-me pelo primeiro portador que deus colocar ao seu alcance 100 tubos de Noir d'ivore, no $11 ; 50$ tubos de Rouge de cadmium foncé, no 10 , e 50 tubos de Blanc de zinc, no 11, Linel 'couleurs a l'huile extrafines'. Tendo estas tintas, recomeçarei a pintar descarregando as minhas tensões, que se condensam como nuvens de um céu em tempestade. Penso que com essa quantidade poderei manter o fogo aceso..."
\end{abstract}

Em Carretel Branco (1967) (fig.33), vê-se como das cinzas dos antigos núcleos em chamas, regressam os carretéis. Os cinza-esbranquiçados, os brancos amarelados, os cinza-azulados recobrem a matéria pictórica que antes era preta. Em outras partes o preto está sobreposto. As espatuladas mesclaram as cores e instauram a imprecisão entre o sobreposto e a subcamada. No meio dessas manchas insinuam-se os contornos de carretéis.

Em telas posteriores, os carretéis transformaram-se em personagens, estão muito mais orgânicos, remetem a um corpo ou a seus fragmentos. Um desenho (fig.34) feito por lberê, em 1973, testemunha essa vontade antropomórfica latente nas figuras dos carretéis na década de 1970. Nesse desenho há duas pessoas estilizadas, uma pode ser palhaço, ou robô. Os botões das roupas de ambas são círculos como os que estão presentes nos carretéis. Por isso, pode-se ver, na tela Figura em tensão (1969) (fig.35), que o preto surge como mancha que se torna carretel, mas, ao mesmo tempo contorno de ser que dança e esboço de uma caveira.

O preto - usado como ora como uma massa de cor, ora como linha deixou de predominar, é uma das várias cores na composição. Parece estar 
latente, submerso na matéria colorida. Adquire configurações variadas. Percebe-se que nas gravuras do início da década de 1970, os intensos contrastes entre o branco e o preto cederam lugar a um jogo cromático, no qual cabiam vários cinzas. As gradações não surgiam como meios tons, transições ou ilusão volumétrica, mas como campos de cor. Assim como cores mais quentes passaram a dominar, não sem drama, as telas.

Em Signos em movimento de 1971 (fig.36), identifica-se um espectro de perfil, em meio a várias figuras em movimento. Alguns carretéis ascendem isolados, outros giram e formam algo que lembra a cruz de Malta, outro remete a uma porta abobadada. Destaca-se, porém, um amontoado de carretéis, um pouco à esquerda do eixo vertical, que configura meio corpo de um vulto de rosto pálido, muito alvo. Está de perfil, o olho vermelho a fitar o extremo esquerdo da tela. Cobre-lhe a cabeça um barrete preto, da mesma cor das vestes que possuem pequenas faixas ocres e vermelhas. A mão esquerda esboça um sinal, parece indicar o espectador.

Esse espectro conecta-se ao retrato do Cardeal Cristoforo Mandruzo (fig.37) de Ticiano. Vale a pena lembrar que, em seu primeiro contato com a grande arte, Iberê impressionou-se com a técnica do italiano. Admirou-se o modo como o mestre era capaz de "criar obras primas com quase nada", com uma paleta reduzida. Escreveu:

"Copiando Ticiano é que posso compreender a sua magnífica simplicidade. Um nariz, uma boca. Tudo se resume numa estupenda pincelada quente ou fria. Aí está toda a abstração! Como ele sabia ver a natureza! Nada é supérfluo, nada é demais! O nosso defeito é ver demais, é meter brilho, é torturar a forma que sempre é plena quando é ampla. Eu não quero esquecer essa lição."226 
No quadro de Iberê, o Cardeal de Ticiano saiu do pedestal, afundou-se na matéria pictórica. A superfície recoberta de tinta ensaia gerar as figuras que habitarão as telas de lberê, em meados da década de 1980.

O drama operado nesse plano vem ao mundo como um freio para a movimentação mais sensual dos carretéis em outras telas. A escolha cromática - na qual o preto passou a sucumbir aos vermelhos, brancos, lilases, rosas, beges - e as bordas um pouco mais sinuosas das figuras alteram o clima nesses quadros. A angústia profunda cedeu espaço para uma chula gaúcha ${ }^{227}$, que apesar difícil e árdua, é uma dança. "Uma festa é sempre para todos", 228 .afirmou Hans-Georg Gadamer, quando criou relações entre celebrações e arte que podem ser aplicadas a essas pinturas. Durante os sapateados gaúchos, como em qualquer festa, surgem momentos de pausa. Também, configura-se tanto nas festas, quanto na arte uma temporalidade própria: o caráter temporal de ambas, justamente por serem celebradas, "não recai na duração de momentos que se revezam" ${ }^{229}$. As telas de lberê têm esse andamento não linear que se repõe a cada instante, que está latente e pulsa. Os carretéis dançam na superfície das telas, ora sapateando isolados, ora valsando em duplas. O preto, nessas telas, é uma das muitas cores que orquestram a dança.

No início da década de 1980, após um incidente no qual Iberê matou um homem $^{230}$, sua paleta recobriu-se de matizes mais frios. Uma atmosfera crepuscular banhou as telas. Como numa reação a impossibilidade de reger a própria sorte, a figura humana começou a esgueirar-se nas telas. Primeiro surge uma mão, depois um perfil, uma sombra. Essa figura angustiada, antes camuflada pelos carretéis, resiste à dissolução, e paulatinamente reaparece. $\mathrm{O}$ 
palco dessa reaparição continua a ser pintura herdeira da grande tradição que não sucumbiu aos novos materiais ou ao contingente. Certa vez, ao ser indagado sobre a razão da utilização da tinta à óleo, Iberê respondeu: "Mas por que eu vou mudar de material, se só agora é que estou conseguindo dominá-lo bem? (...) gosto da voluptuosidade da pasta à óleo. E não pretendo abandonála"231. Mas tanto a fatura - ato quase obsessivo de pôr, raspar, e repor a tinta e, quanto a forma - feita, destruída e refeita - traem e ao mesmo tempo revelam que aquela superfície era campo de batalha contra a dissolução na arte na vida. Batalha que, mesmo declaradamente vã, permanecia enquanto relato. O pintor declarou, mais de uma vez, ser um dos últimos guardiões dessa tradição que se esgarçava, influenciado pelas relações indissociáveis entre pintura e vida:

"Sempre andei na contramão, sempre caminho ao contrário das multidões. O que me ocorre é que essa minha pintura se parece muito comigo, porque o que faço é também uma expressão da minha maneira de ser como homem. Está muito ligado... eu como homem, como criatura na sociedade, com o que eu faço"232.

Hora $V$ (1983) (fig.38) é uma tela de uma horizontalidade enfática. O observador tem duas opções para apreendê-la em sua totalidade: ou afasta-se o suficiente para enxergá-la como uma unidade, ou a observará aos pedaços, sendo obrigado a completar o conjunto em sua mente. $O$ olhar vaga pela tela sem encontrar um porto seguro. Os carretéis imiscuam-se ao fundo. Não sabemos se eles estão sobre ou brotaram da massa de tinta. Trêmulos: o movimento de expansão foi freado, mas as figuras, ainda assim, tentam inutilmente se libertar. Entre as imagens há uma sombra do pintor. As mãos estão espalmadas, como se pedisse calma ao tumulto camuflado. A figura bastante escura, um preto chumbo, está contornada por linhas brancas. A presença da sombra na tela desencadeia uma série de associações que, assim 
como a tensão da composição, sobrepõem-se desordenadamente. A sombra pertence ao mundo físico, mas não possui matéria, é incorpórea. Ela está sempre conectada ao corpo opaco que a gera, mas tem uma dinâmica própria. Sombras surgem e desaparecem, crescem e decrescem, tremulam, assim como tudo nessa pintura de Camargo.

A silhueta de lberê remete às sombras de De Chirico (fig.39 e 40) que, repletas de ambigüidades, percorrem arcadas italianas. Silhueta e sombras que têm em comum o fato de expressarem "a solidão e o mistério que envolve as

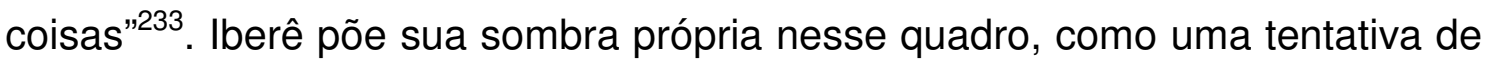
que a ligação com a tradição o impeça de desintegrar na tragédia fortuita. Funciona como uma sombra fossilizada e plana que elimina a volumetria do corpo que a gerou. As gradações de luminosidade, que criariam volume, foram resumidas a uma pretidão, plana, densa e opaca. Um preto que confere ao espectro uma ambigüidade entre a presença e a ausência, entre o profundo e o superficial. Em meio às oposições, as mãos agitadas da figura parecem pedir uma pausa, movem-se e solicitam um pouco de calma.

O preto, em diversas das telas posteriores de lberê, surgiu como linha ou como uma subcamada que, recoberta pelos matizes, criava a atmosfera de penumbra. $\mathrm{O}$ preto da base brota sob as incisões que formam as figuras e também constrói a bruma plúmbea ${ }^{234}$ que as envolve. Iberê extrai, diretamente do tubo, a linha que delineia algumas dessas figuras. Num processo aparentemente contraditório, o tubo do qual a tinta é extrudada cria sulcos na superfície pictórica. Assim as linhas pretas que contornam as figuras são tinta e falta de tinta, protuberância e cavidades. Enquanto protuberância é tinta Noir d'lvore pura sem mistura, já a cavidade é rastro colorido pela raspagem das 
camadas preexistentes. Essas linhas criam os personagens, mas formam um limite tênue que impede sua dissolução na superfície. Por um lado servem como solda: estão presentes para impedir que as figuras se destaquem da massa de tinta, para que as figuras se fundam, mantendo-se como campos cromáticos distintos. Por outro são cicatrizes, apontam para o processo de criação:

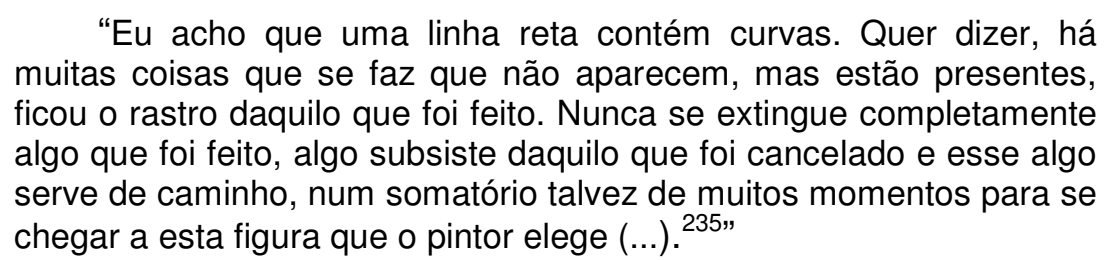

A paleta usada por lberê na última década de sua vida cria telas que encenam um grito contido, um silêncio forçado, um noturno alegórico. Paleta tributária da "cor na pele arroxeada das figuras de El Greco"236. O azul, o roxo, o preto menos densos e as cicatrizes deferidas pelos os tubos de tinta tornam a atmosfera sombria. Criam um mundo arruinado no qual o sujeito, apesar de desenganado, solitário, ainda vive. Na tela Tudo te é falso e inútil IV (1992) (fig.41), uma personagem está sentada ao lado de uma mesa, da qual carretéis pretos caem. Há uma ambigüidade nessa figura, não se consegue definir se é um homem ou uma mulher, se possui matéria ou se é desencarnada. Inerte, não consegue impedir o desmanche que está ocorrendo. Ao seu lado, diferentemente das mesas com arranjos estáveis de carretéis, os objetos despencam. A figura parece conformada com a impossibilidade de se criar uma nova Mesa azul com carretéis (1959) (fig.28) e com o esvaecimento que se aproxima.

Ao longo de sua trajetória, Iberê se baseou em referências para sua pintura, carretéis sobrepostos numa mesa ou a uma modelo que se posava em 
sua frente. ${ }^{237}$ Ele criava quadros num embate direto com o plano pictórico, um ato obsessivo de construir e destruir. Mas fazia também estudos. Desenhos projetivos, feitos com um gesto rápido, contém os elementos dos quais germinará a pintura,englobam questões que serão postas na tela. É tradução gráfica de seu modo de enxergar. Não um esquema para ser seguido cegamente, mas um elemento do processo:

\begin{abstract}
"O desenho sempre acompanha, pois tenho necessidade de definição... Trabalho procurando lidar com grandes planos, grandes volumes se for o caso, como os grandes mestres do passado. Eu sempre prestei atenção a esta síntese da pintura dos clássicos. E acho que dentro do moderno de hoje (falando de seu trabalho) também há essa intenção de síntese e amplidão da figura. Não é como se vê, porque aqui há algo que passa além do modelo."238
\end{abstract}

Há esquemas cromáticos. Alguns feitos a lápis, outros com canetas, outros com guache e nanquim. Os pretos de guache são opacos, fortes, aveludados, azulados. Os pretos de nanquim são mais transparentes e avermelhados. Esboços com indicam por escrito o nome de cores (fig.42). $\mathrm{O}$ uso das palavras ressalta o caráter cambiante da paleta de Iberê. Nesses desenhos encontramos especificações como preto, preto azulado, arroxeado, roxo azulado etc. Sua pintura reflete essa riqueza de nuanças. Há pretos, mas exceto quando é linha extraída diretamente do tubo, nunca é um preto pronto, puro. Transpira as outras cores que se mesclaram para gerá-lo. Respiram-se vermelhos, verdes, ocres, azuis, que se alternam sob a massa de transparência preta densa. É um preto azulado, ou um preto esverdeado, ou um preto arroxeado. Escuro como a casca de um besouro, que reage à luz e revela toda a gama colorida. Um preto que pulsa por alternar a escuridão e o espectro cromático. O preto de lberê conjuga pares opostos. Morte e nascimento, escuridão e luz, falta de cor e espectro cromático, desilusão e esperança articulam e coabitam as telas. 
Fig.26

Iberê Camargo

Cadernos de 1948/1949 
Fig 27

Iberê Camargo

Garrafas (1957)

óleo sobre tela $65 \times 100 \mathrm{~cm}$

Fig 27 a

Desenho

Fig 28

Picasso

Tijela verde e Garrafa preta,

1908

Hermitage São Petesburgo
Fig 29

Morandi

Natureza Morta , 1939

óleo sobre tela $44.0 \times 51.4 \mathrm{~cm}$ 
Fig.27

Carretéis com três laranjas(1958

)

óleo s tela $62 \times 100 \mathrm{~cm}$

Fig.28

Mesa azul com carretéis (1959)

óleo s tela $100 \times 62 \mathrm{~cm}$

Coleção Particular

Fig.30

Estrutura(1961)

óleo sobre tela $88 \times 113 \mathrm{~cm}$

Museu Nacional de Belas Artes-Rio de Janeiro 
Fig.32

Núcleos (1965)

Óleo s tela $150 \times 212 \mathrm{~cm}$ Coleção Cristovão Moura
Fig.33

Carretel Branco (1967)

Óleo s tela $55 \times 95 \mathrm{~cm}$

Coleção Particular تig. 31

Estrutura dinâmica (1961)

óleo s tela $115 \times 199 \mathrm{~cm}$

Coleção Particular 
Fig.34

Desenho sem título 1973

Fundação Iberê Camargo
Fig. 35

Figura em tensão

Óleo sobre tela $(93,1 \times 132 \mathrm{~cm})$

Museu de Arte do Rio Grande do Sul 9 
Fig.37

Ticiano

Retrato do Cardeal Cristoforo

Mandruzo(1552) óleo s tela 210 x $109 \mathrm{~cm}$

MASP
Fig.38

Hora V(1983)

Óleo sobre tela $95,5 \times 214 \mathrm{~cm}$

Coleção Sattamini 
Fig. 39

Tudo te é falso e inútil IV (1992)

Óleo sobre tela

$200 \times 236 \mathrm{~cm}$

Fundação lberê Camargo Porto Alegre 


\section{Espelho negro.}

Vagante no vento negro; baixo sussurra o junco seco No silêncio do pântano. No céu pardo

Segue um bando de aves selvagens;

De través sobre águas escuras.

Tumulto. Numa cabana em ruínas

Esvoaça com asas negras a podridão;

Bétulas aleijadas gemem no vento.

Anoitecer em taberna abandonada. Fareja o regresso

A melancolia suave de rebanhos que pastam,

Aparição da noite: sapos emergem de águas de prata.

Georg TrakP ${ }^{239}$

Eduardo Sued fez, entre 1980 e início da década de 1990, pinturas nas quais a tinta preta existente na paleta física se transforma em área tensa preta. O quadro é composto por vastas áreas de cor, ladeadas por faixas coloridas. $O$ preto funciona como uma cor qualquer, não dominante, na orquestração colorida. Em outras palavras, é um dos vários elementos necessários para a existência do quadro. A solução encontrada para a composição é, por muitas vezes, o conflito e não a consonância. O preto, assim como qualquer outra cor, mantém sua singularidade cromática, exibe seu tom característico. A colocação desses tons cria, por vezes, contrastes estridentes, colisões dos campos cromáticos que desestabilizam a superfície. Existência conflituosa, na qual os matizes não ressoam uns nos outros, não se atenuam, não se suavizam, ao contrário, digladiam.

$\mathrm{Na}$ tela sem titulo, 1987, (fig.43), o esquema de cores é intenso e dissonante. Rastros do pincel quase não são vistos. Num relance parece que a tinta foi depositada com rolo. Como em outras obras desse período, os 
axiomas construtivos de Mondrian ecoam, como pergunta, e não como afirmação. Sued parte do atributo ortodoxamente plano e simplificado do neoplasticismo para questioná-lo, e não reafirmá-lo. Nota-se que o pintor carioca compreendeu como a redução e a ordenação claras, que constituem o vocabulário pictórico de Mondrian, fazem com que as obras, dentro se sua aparente simplicidade, aparentem não estar contidas pelo contorno. Conforme afirmou: "Um quadro de Mondrian está sobre a parede e, no entanto, não constitui uma janela, um furo nela. É como se o quadro fosse inerente a ela, Ihe pertencesse. $\mathrm{O}$ entorno da tela parece vir a ser sua própria extensão."240 A dilatação das formas dentro da redução dos meios foi um dos ensinamentos aplicados por Sued.

Ele estudou a paleta do holandês. Em suas palavras: "percorri e assimilei as relações possíveis entre as tonalidades usadas por Mondrian, formando, a partir delas, um jogo de variantes."241 Analisou como faixas pretas interagem com as áreas retangulares das cores primárias (vermelho, azul e amarelo) que interagem com os espaços brancos e cinzas que interagem com as faixas pretas. Percebeu a tensão dinâmica da composição. As áreas geométricas parecem tentar liberar-se das grades nas quais estão inscritas. Desvirtuar sutilmente a aparência estática da superfície foi outra lição aprendida.

O quadro de Sued não é somente uma explosão de um fragmento de uma tela de Mondrian, mas é a ampliação do caráter expansivo e dinâmico que era ensaiado nos quadros do precursor. A verticalidade e a horizontalidade, os retângulos e as faixas alongadas são elementos formais comuns aos dois. Num olhar desatento as paletas se assemelham. Mas o brasileiro, deliberadamente, distorce as premissas básicas da redução cromática do pintor holandês. 
Agrega verdes e rosas que desestabilizam ainda mais o conjunto. As faixas de cor ensaiam trocar de lugar. $\mathrm{O}$ movimento é iminente, mas não se realiza. $\mathrm{O}$ olhar não consegue se acomodar. Vagueia na superfície. Pula entre um campo cromático e outro na tentativa vã de capturar o conjunto.

Assim como ocorre com as demais cores, o preto, nessa telas, trabalha pelas relações de tensão. Por exemplo, a faixa preta colocada na parte inferior da área verde, é completamente diferente daquela, também preta, de idênticas dimensões acima da vermelha. Isso ocorre, pois a articulação com os outros campos de cor, no interior da tela, cria sensações de expansões distintas. As extensões coloridas, nas quais aparentemente não há resquício do gesto, parecem estar esticadas à beira da ruptura devido às pelejas cromáticas. Mas, como essa impressão é causada pelas relações no quadro, o estiramento deixaria de existir caso alguma daquelas cores não estivessem na tela. Essa talvez seja uma das razões pela qual a dimensão percebida dessas pinturas de Sued parece extrapolar seus limites físicos. Como escreveu Rodrigo Naves sobre essas telas, os "formatos oscilam incertos entre sua extensão física e a dimensão sensível dos trabalhos, com verticais que não ascendem e horizontais que não repousam"242. Uma expansão que ocorre na superfície da parede, como se o chassis não delimitasse a área do quadro.

Em vez de haver uma ilusão de profundidade, de um espaço para dentro da tela, há um jogo cromático que provoca uma nova espacialidade baseada na superfície da tela. $O$ análogo desse espaço deixou de ser a janela para se tornar uma grelha (grid) ${ }^{243}$ de ordenação das áreas de cor. Como os campos cromáticos parecem resistir à ordenação, cria-se uma tensão permanente entre a geometria e a cor. 
Nas obras criadas a partir do início da década de 1990, as tensões cromáticas se alteraram. A paleta, por um lado, acumulou, e por outro, parece ter sintetizado as soluções cromáticas anteriores. As telas podem tanto apresentar as aproximações conflitantes - seja pelo emprego de tons fortes, seja na justaposição de áreas opacas com áreas brilhantes com áreas metálicas - quanto afirmar o domínio da utilização de variações sutis de um mesmo matiz, que cria campos cromáticos de vibrações diversas. Alguns conflitos cromáticos são gritantes, outros tornaram-se paulatinamente sussurros. A tensão cromática existe, mas ao plano da pintura incorpora-se a materialidade, a densidade de tinta. Na superfície da tela vêem-se de forma explicita as marcas largas e explícitas das pinceladas.

Cores mais escuras preponderam como monocromos neutros, que excitados pela ação da luz revelam sua policromia velada. Há uma constante oscilação entre a opacidade, que suga o olhar, e o brilho, que o repele. Os antigos planos retesados cedem lugar à turbulência maciça. Na pintura, tornada corporeidade na mais rigorosa planaridade, surgem além de grandes áreas pretas, áreas negras. Essa diferença surge pelo modo de aplicação da tinta, pelo tipo de tinta usada e por outro elemento que se instaura na gramática do pintor: a colagem, que provoca alterações cromáticas conforme o suporte. O preto aplicado sobre o metal difere daquele aplicado na madeira, que se comporta diferentemente do aplicado sobre o papel. A precisão da composição cria um jogo sóbrio de expansão e contenção.

Em várias telas dessa fase, há um contraste entre áreas pintadas com esmalte sintético e áreas pintadas com massa de emulsão óleo/acrílico. Em várias delas, as áreas nas quais foi aplicado e esmalte, fica com uma saturação 
de preto tão intensa que se torna área cromática negra. A tela sem título (fig.44) guarda relação com as dimensões de um portal. Um retângulo alongado negro está apoiado numa estreita faixa azul. O contraste entre os pretos da tela cria esse espaço, para dentro da faixa negra. O esmalte sintético, aqui, perde a característica da pintura industrial, impessoal, para viram campo de cor.

O comportamento de negro é diferente na sem título (fig.45).. Aqui são três áreas centrais pintadas em negro, cada uma apoiada numa faixa azul avioletada. Áreas, que apesar de espessas, permitem que o olhar se encaminhe para dentro da tela. Como uma poça de petróleo, a viscosidade da matéria dificulta mas permite que se vislumbre algo interior. A poça pode ser rasa, mas ao olhar é vetado achar o fundo. Essas áreas de Sued recriam a luminosidade do ambiente circundante, que passa a fazer parte da obra. Os reflexos, apesar de fugidios incorporam a pintura, são como a água que preenche a piscina na analogia de Merleau-Ponty:

\footnotetext{
"Quando vejo através da espessura da água o revestimento de azulejos no fundo da piscina, não vejo apesar da água, dos reflexos, vejo-o justamente através deles, por eles. Se não houvesse essas distorções, essas zebruras do sol, se eu visse sem essa carne a geometria dos azulejos, então é que deixaria de vê-los como são, onde estão, a saber: mais longe que todo lugar idêntico. A própria água, a força aquosa, o elemento viscoso e brilhante, não posso dizer que esteja no espaço: ela não está alhures, mas também não está na piscina. Ela habita, materializa-se ali, mas não está contida ali, e, se ergo os olhos em direção ao anteparo de ciprestes onde brinca a trama dos reflexos, não posso contestar que a água também o visita, ou pelo menos envia até lá sua essência ativa e expressiva. É a animação interna, essa irradiação do visível que o pintor procura sob os nomes de profundidades, de espaço, de cor". ${ }^{244}$
}

A superfície, porém, ao refletir o ambiente, mesmo que de modo distorcido, cria um espaço virtual. A luz jamais entra na tela, mas incide e ricocheteia. Quando volta e atinge o olho, nos fornece uma ilusão de 
profundidade, de sobreposição de planos. Cria um lugar que não conseguimos determinar onde está. $\mathrm{O}$ olhar pode vagar nesse espaço, penetrar na sua virtualidade e perder-se. O reflexo especular cria uma imagem com lugar indeterminado. Indeterminação que permite denominar de negras, no sentido proposto aqui, essas superfícies. Ou seja, há uma espacialidade para dentro da tela, pode-se caminhar para o interior, mesmo que neste caso seja um interior virtual. O lugar está sobre ou está dentro da tela? O espaço refletido por ela é irreal, pois o que vemos não está lá mas, ao mesmo tempo, a imagem criada serve de instrumento que nos permite identificar o ambiente que nos rodeia e, portanto, rebate onde estamos realmente. A pintura negra cria um duplo especular distorcido, embaçado do local onde está o observador.

Michel Foucault discorreu sobre a ambigüidade do espaço criado por espelhamentos. Definiu dois tipos de espaço existentes na contemporaneidade: a "utopia", ou seja, lugar sem lugar real, espaço fundamentalmente irreal e que apresenta a sociedade de maneira melhorada ou distorcida, e a "heterotopia", um lugar efetivo no seio da sociedade, mas que simultaneamente apresenta e contesta todos os outros posicionamentos encontrados no interior da cultura. O espelho oferece uma mistura da experiência desses dois lugares. É uma "utopia", pois, ao olhar um espelho, o observador se vê num espaço ilusório, virtual, onde não está. Ele se vê num espaço que foi aberto para além da superfície, num lugar de onde está ausente. Ele passa a ser uma sombra que Ihe dá visibilidade de si mesmo. Mas além de "utopia", espelho é um lugares real, ou seja, uma "heterotopia", no sentido que sua superfície exerce um tipo de reação à posição ocupada pelo observador. Converte o lugar no qual o observador está quando se vê no espelho, num espaço ao mesmo tempo 
categoricamente real, incorporado a todo o espaço que o circunda, e absolutamente irreal, pois, para que esse espaço real seja percebido, o observador tem de atravessar a superfície e chegar no ponto virtual que está do lado de lá. A partir do momento em que olha para si na base do espaço virtual que se encontra do outro lado do espelho, ele passa a se reconstituir a si próprio naquele lugar onde está, com tudo aquilo que o circunda. ${ }^{245}$ Ao fitar um espelho, olha-se para frente e vê-se, além da própria imagem, aquilo que está atrás de quem olha. Além disso, observar-se no espelho permite ao sujeito conhecer a parte de seu corpo mais significativa para sua identidade: seu rosto. A própria face é uma incógnita, está fora do campo visual, até o indivíduo perceber-se num espelho.

Essas telas podem ser analogias ao modo de funcionamento de espelhos, não exclusivamente pelas áreas que refletem o ambiente, mas pelo jogo entre essas áreas e as outras nas quais vemos, insidiosamente, as marcas do fazer. As telas apresentam a existência de uma relação inversa entre a falta de lustre, que dá a visibilidade às características físicas da superfície, e a qualidade da imagem refletida, quanto mais perceptível forem as características da superfície, mais nebulosos tornam-se os reflexos. Em um espelho, a superfície torna-se invisível para permitir que apareça a imagem especular. Os materiais muito foscos permitem que se perceba toda a textura e todos os detalhes da superfície, mas não criam reflexos. As telas não são espelhos nem matéria totalmente opaca, mas referenciam ambos. Vale a pena citar que espelhos, ao longo da história da arte, foram usados como paradigmas da pintura. Fez-se a analogia entre as imagens projetadas na superfície de um espelho, e as criadas pelo pintor, pela adição de pigmento sobre a superfície opaca dos 
quadros $^{246}$. Pintaram-se espelhos para questionar a posição do pintor e/ou do observador na cena pintada ${ }^{247}$. Mas, também, espelhos foram usados como instrumentos para auxiliar a pintura.

As áreas esmaltadas negras (fig.46) remetem a um espelho negro, mais especificamente àquele conhecido por espelho de Claude ${ }^{248}$. Pequeno espelho convexo preto, assim chamado, pois as imagens nele refletidas tinham as cores esmaecidas da pintura do artista francês do século XVII, Claude Lorraine. Instrumento que foi usado por artistas do século XVII e XIX, como acessório da captura da paisagem. Permitia que os artistas enquadrassem somente o trecho que queriam pintar e ficassem de costas para o conjunto da paisagem. Ficar de costas para o que se quer ver é uma das metáforas que Sued aplica em relação à fruição de uma obra de arte. O pintor afirmou, certa vez, que um quadro é para ser visto de $\operatorname{costas}^{249}$. Isso significa que um quadro exige um olhar que não seja especulativo e codificado. Exige um olhar despojado e autêntico.

As telas são compostas por tons escuros, pretos e negros, mas nem por isso tornam a tela sombria. A luz emerge de sua superfície como se reagisse a um movimento interno do quadro. Tem um comportamento diferente nas áreas não espelhadas. Responde à materialidade das pinceladas turbulentas, absolutamente visíveis. No restante da tela uma densa massa composta por tinta preta parece recobrir um colorido que pode ser entrevisto pelas arranhaduras retilíneas que marcam a superfície. Divisam-se pretosavermelhados, pretos-azulados, pretos-arroxeados, cor de chumbo, cor de grafite, conforme a incidência luminosa. Sua topografia pode ser percebida. A rugosidade da matéria é enxergada. O olhar desliza pelo relevo sutil, sem 
conseguir adentrá-lo. O preto funciona como um anteparo, o observador pode mapear o relevo da massa de tinta, mas não ver o seu fundo, exceto por incisões feitas na pintura. A variação do sentido das pinceladas cria uma trama que faz com que o olhar não encontre um centro, funciona como os arabescos usados nas telas de Matisse.

Ao colocarmos a obra no contexto da história da arte, podemos recuar até Velásquez. Mestre que pintava um manto ou o lombo de um cavalo, como uma área chapada preta. Mas, mesmo o espectador não iniciado pode apreciá-la e compor outras correlações. Os retângulos escuros insinuam a existência de outro lado, de algo para além da superfície, mas jamais permitem penetrar no seu interior. Não criam um buraco, ou um vão, mas sim um mistério. Se nos fosse permitido ver, o que encontraríamos no interior do quadro?

Nessas e em outras telas, a superfície ondula como marola incessante. Como a superfície do mar, a tela a cada instante se altera. Pretos emergem, não de forma trágica ou tenebrosa, mas, com um toque de mistério e sensualidade. Algo de tecido lustroso, sedoso surge nessas obras. $O$ jogo de brilhos e opacidades remete a adamascados ou ao movimento da seda ou do cetim. Já o mistério surge, pois o quadro não se revela totalmente ao olhar e distorce a percepção do local no qual se localiza o observador. Pode haver uma cor escondida, que somente aparece em certa iluminação. Pode haver um espaço para dentro do quadro, mas isso não é afiançado. $O$ quadro expõe enigmas intrínsecos a um mundo noturno, que não é aterrador. Tragédia não pode ser lida nessa obra, mas promessas. A tela é como uma noite que insinua a lubricidade da seda, a voluptuosidade do veludo, mas nunca a transparência do tule. 
É interessante notar que Sued usou, mais de uma vez, panos, sem chassis, para tratar de questões da pintura. Em 1998, o Centro de Arte Hélio Oiticica, no Rio de Janeiro sediou a exposição Eduardo Sued pinturas 19801998. Além de estar em várias telas, ora como superfície retesada, ora como massa crispada de tinta, a cor preta materializa-se também num pano na instalação Em torno de H.O (fig.47), inspirada num bordel localizado nos arredores do centro cultural. Amplas faixas de seda preta pendiam, escondendo e ao mesmo tempo revelando, uma pintura na parede. Remetiam aos cortinados presentes em toda a história da arte, que postos no primeiro plano serviam para separar o espaço do observador do espaço do quadro, ocultar uma parte da cena pintada. Sob o tecido, viam-se dois pequenos retângulos roxos, nas laterais da parte inferior. Duas tiras verticais brancas, também nas laterais, insinuavam uma pintura grande escondida. No meio da área delimitada pelas faixas, por uma fresta entre os tecidos, entreviam-se tons de rosa e vermelho que se recusavam à estabilidade, mudavam de tonalidade conforme o movimento do observador. A seda preta era um anteparo, resguardava e compunha a obra. Se por um lado ocultava a pintura, por outro completava o espaço pictórico criando diversos tons de preto devido ao caimento do pano. Essa obra, posta ao lado das pinturas, avigora essa aparência têxtil das superfícies encrespadas. Remete à loja de armarinho, com as torres de tecidos que ondulam até o chão e as gavetas com as linhas e cadarços, na qual Sued trabalhou na juventude.

Colar distintos materiais foi outro procedimento usado por Sued para perturbar a superfície da tela, nas obras a partir da década de 1990. Mas a colagem, aqui, não traz para a tela os elementos extraídos da vida cotidiana. 
Não encontraremos rótulos, recortes de jornal, embalagens. Encontraremos sim, metal, madeira, tecido e papel, que também podem estar pintados. Elementos que, ao serem pintados, alteram, não exclusivamente o preto, mas qualquer cor empregada. A colagem é uma protuberância no plano da pintura, é mais um elemento sobre o qual a luz trabalha. Como disse Paulo Sérgio Duarte: "colagem agora é um sobressalto da pintura, talvez tenha a ver com a revolta da superfície diante da impossibilidade da ilusão de profundidade cuja destruição foi consumada pela própria história da arte." ${ }^{250}$ A materialidade literal substitui, ou melhor, incrementa, a composição estritamente pictórica. Sued não quer criar uma ilusão volumétrica, por isso lança mão da construção material de um espaço, avança para fora do plano da tela (fig.48).

A experimentação constante e a agregação de outros materiais contribuíram para a mutação das obras feitas nos anos 2000. As protuberâncias, que eram sutis, ampliaram. Desfiguraram o contorno das obras. O perímetro de várias telas não é mais regular, o pintor agregou pedaços de madeira n'algumas obras. Tocos avançam para frente, vigas para as laterais. Há certa precariedade na junção desses elementos, que perturba a forma. Temos a materialidade bruta da madeira que pode estar revestida por um preto intenso. Mas, mesmo preta essa madeira não parece estar carbonizada, ela está pintada. As estruturas, se não fosse pela a vitalidade da cor, poderiam remeter às favelas cariocas. Mas a cor impede essa leitura. Há uma precariedade caprichada, elaborada. Nessa vontade de redenção pela cor e pela forma, ecoam, mesmo que enfraquecidos e desacreditados, algum resquício das propostas da Bauhaus. No sentido definido por Giulio Carlo Argan: 
"Bauhaus significa 'casa da construção'; por que uma escola democrática é uma escola da construção? Porque a forma de uma sociedade é a cidade, e, ao construir a cidade, a sociedade constrói a si mesma. No vértice de tudo, portanto, está o urbanismo, porque cada ação educativa ensina a fazer a cidade e a viver civilizadamente como cidadão." 251

Sued trabalha diariamente em seu ateliê situado num condomínio em Jacarepaguá, no Rio de Janeiro. Há duas possibilidades de chegar lá. Pode-se atravessar parte da Barra da Tijuca, e seguir pela estrada de Jacarepaguá, onde há diversos condomínios de classe média alta. Ou dirigir pela linha Amarela, margear a Cidade de Deus, e atravessar diversos assentamentos urbanos de classe mais baixa. A realidade da cidade maravilhosa, cuja tensão entre as classes sociais diferentes que habitam regiões adjacentes parece não encontrar solução sem conflito, acaba por querer aparecer nessas telas de Sued.

Circundado por uma vegetação exuberante, o ateliê é inundado pela luz natural durante o dia inteiro. Muitas obras estão dispostas pelas paredes ou nos teleiros. As telas traduzem mais suas reflexões a respeito da arte e das cores, que seu sentimento em relação ao mundo. O estado emocional pode sim influenciar a escolha de uma cor, mas não determina o andamento da obra. Suas indagações sobre o preto e o negro já foram documentadas diversas ocasiões. Vale a pena transcrever a explicação dada a lleana Pradilla e Lúcia Carneiro, em 1997:

"A cor preta, por exemplo, é a mais sombria das cores, mas até sua própria escuridão depende também do sei entorno. Num contexto de cores claras, ele se torna mais sombrio do que um mesmo preto em contexto sombrio. $E$ se torna também mais intenso. Dependendo do caso, é possível afirmar, por exemplo, a luminosidade do preto. Digo que o preto caminha para o negro é na medida em que a escuridão e a intensidade vão se apossando dele. $E$, se pudéssemos passear pelo preto, perceberíamos que ele nos permitiria o passeio apenas em sua superfície, enquanto o negro não nos impediria de passear por dentro, nos levando para o fundo dele. Por isso falo da opacidade do preto e da transparência do negro. Vale a pena 
observar que transparência, aqui, não significa a existência de alguma coisa atrás dele, mas o fato de se poder atravessá-lo, permanecendo nele.

Nomeio pretos neutros os preto-de-marfim e de-marte, e pretos cromáticos os pretos compostos pelas misturas dos pretos neutros com outras cores, das quais se excluem os brancos e os cinzas. Haverá, portanto, pretos com matizes, subtons verdes, vermelhos, amarelos etc. A neutralidade dos pretos não é absoluta pois, inerentes a eles, se detectam sutis tonalidades azuis dos pretos-demarfim, e alaranjadas dos pretos-de-marte. Há noites pretas e noites negras! ${ }^{252}$."

Declarou, oito anos depois, em uma entrevista concedida a Lígia

\section{Canongia, Luiz Camilo Osório e Roberto Conduru:}

"Não sou especialista em preto, porém tenho a mania de falar sobre os pretos e distingui-los entre si, dizendo que um é mais quente, que o outro é um negro, negro, que outro tem um subtom violeta etc. Na Europa vendo Soulages, senti que ele tinha uma orquestração de negros empolgante, com uns vazamentos brancos repentinos. Já tinha a mania de fazer coisas pretas, bem antes. Até hoje continuo, e nem sei de onde vem esse negrume... É só à noite que o deserto é negro?"253

Afirmou, 2008:

"Pintura é o ambiente no qual espaços, planos, cores, linhas, pontos etc., se relacionam segundo uma ordem, não nominável, advinda dele mesmo e de minha própria experiência. O que ocorre num ambiente preto/negro ? Estimo que haja graus de saturação de preto, e, o de maior energia preta é o negro. Saturar um branco, isto é, torná-lo mais branco, com mais energia branca que o branco de prata,por exemplo, - o branco mais branco conhecido, nominável - é possível pela entourage. Isto é, pela presença de cores que estão a seu lado. Feito já conhecido pelos antigos pintores. Portanto, o conteúdo escuro dos pretos e dos negros também se desvanece ou se intensifica por sua vizinhança. Um branco vizinho os torna mais saturados e mais luminosos. $E$ as tonalidades cinzas, por exemplo, menos saturados e luminosos. A saber: colocando um branco ao lado, ou em torno de um preto ele se torna mais saturado, mais preto, com mais energia escura. Dai os planos complexos de pretos e de negros no ambiente preto/negro." (Informação verbal) ${ }^{254}$

Além da vizinhança, a quantidade de um preto, por exemplo, altera sua saturação: a superfície de um negro é mais negra que a superfície menor desse mesmo negro. Guaguin dizia que um quilo de vermelho é mais vermelho que meio quilo desse mesmo vermelho.

As diversas saturações de pretos e negros criam, portanto, em seu ambiente, planos de fortes contrastes.

Há na trajetória de Sued, alguns fatores que podem ter fomentado a sensibilidade para as variações da cor preta. Como Manet - que afirmou ter 
aprendido muito sobre pintura nas noites intermináveis quando observava o jogo de luzes e sombras da esteira do navio e durante os dias em que, debruçado no deck, fitava o horizonte ${ }^{255}$ - Sued citou várias vezes a importância da superfície d’água para a sua pintura. Reflexos da relva vindos do fundo das águas do Rio Guaíba foram observados da balaustrada de um navio. Quando jovem, "pegava jacaré" no Arpoador. Ficava apoiado numa prancha de madeira, boiando enquanto esperava a onda certa. Olhava o mar, as ondulações da superfície, o lugar no qual o mar encontrava com o céu, a linha do horizonte, o espaço e o vazio..

Ele afirmou que ter observado as superfícies d'água, à noite, pode ter aguçado sua sensibilidade para os tons sombrios. Disse:

"As ondulações da superfície realmente criam um clima, criam um espetáculo de luz e sombra. E nessas sombras, muitas vezes eu percebo a presença do negro e do preto. A nossa sombra, o nosso escuro é diferente do escuro da Europa, por exemplo. A presença do negro é muito mais evidente aqui na América do Sul". 256

Sued, assim como Iberê Camargo, esteve na Europa no Pós-Guerra. Entre 1951 e 1953, ficou em Paris. A cidade se recuperava dos danos sofridos nos anos anteriores, somava-se à escuridão das ruas, o preto proposto pelo existencialismo. Conforme afirmou:

“(...) realmente era o que eu presenciava todos os dias. Eu saía: preto. Primeiro a paisagem: o que eu via era realmente muito sombrio. Com a falta de luz, causada pelo racionamento. Pela dificuldade de ter saído de uma guerra terrível, Paris foi uma cidade não-luz. Naquela época, realmente foi a cidade do escuro, da não luminosidade. Pretidão era constante nas fachadas dos edifícios. Muito além de estar danificada, a cidade se apresentava muito escura. Algo muito triste mesmo.Eu via e foi o que ocorreu. Por outro lado, repare que, naquela época, a moda era o preto. O preto era uma presença diária nas pessoas que lá viviam. Eu sentia isso. A Juliette Greco, por exemplo se apresentava, assim como a Edit Piaf também se apresentava, com roupas pretas.Naquela época, não sei se em sinal de luto, pois se tinha saído de uma guerra, não sei por que razão, mas de fato que a presença do preto era muito importante. Talvez o existencialismo também tenha influenciado. A filosofia do 
Sartre colaborou muito, muito, para que se adotasse o nãocolorido.Eu acho que sim, é isso ai. Mas de qualquer maneira, me presenciou. Foi uma época importante, porque estávamos em Paris. Paris era a cidade criativa, grandes movimentos. Tudo lá surgiu: a arte moderna, cubismo etc. O preto era uma presença, porque era o tom da época" ${ }^{257}$

Os cafés eram pontos de encontro, Sued participava de conversas sobre arte, poesia, cinema. Interessava-se por poetas expressionistas alemães, pelo silêncio e clima noturno proposto por Georg Trakl:

"Eu tenho a impressão de que ele lida muito com esse clima do oculto, do escuro, do não dito. Isto me fascinava muito. A questão do crepúsculo, da tarde, do noturno ou mesmo da escuridão. Eu sinto que essa questão do sombrio, do escuro, é uma presença em mim. Por isso que talvez o negro, que é a suprema escuridão, o negro, seja tão caro a mim. Tem aquele lado, o lado do mistério, do desconhecido, do que está atrás. $E$ isso e é um mistério. Isso me fascina muito, porque no fundo a arte é um mistério." (Informação verbal) ${ }^{258}$

Sua formação artística foi ligada às questões postas pela Escola de Paris, mais especificamente por Matisse e Picasso, e manteve-se distante da pintura norte-americana. Visitou os museus e observou - além dos planos frontais pintados na Ronda Noturna de Rembrandt, no Atelier Vermelho e nas grandes colagens de Matisse, nas obras dos pré-renascentistas - como "Manet usava o preto com grande maestria, assim como Goya, Rembrandt e Velásquez também"259.

Não se pode menosprezar a eventual relação entre o preto na pintura e a prática da gravura em metal. Na volta para o Brasil, em 1953, Sued passou a freqüentar o ateliê de lberê Camargo, onde aprendeu água-forte, água-tinta, maneira-negra, etc. A prática da gravura em metal, segundo afirmou: 
“Exige uma precisão técnica, além da visão. É preciso ter uma visão bem rigorosa. A visão tem de estar clara. O olho precisa estar muito atento, porque se trabalha no escuro. No começo da gravura em metal na água forte, por exemplo, se passa o verniz preto. Você trabalha sobre um muro preto. Você precisa ter um olhar afiado. Um olho físico afiado para desenvolver o seu trabalho. É um esforço muito grande. [...] Fazendo gravura, a presença do preto e da luz: 0 branco, começam, então a aparecer em mim" (Informação verbal) ${ }^{260}$

O contraste, a oposição entre um e outro elementos que, na gravura, se dava entre o branco e o preto, ocorre em algumas pinturas entre o preto e 0 negro, em outras entre o preto e as cores, ou entre os diversos materiais que, pintados, são agregados à superfície do quadro. Há uma tensão constante. As noites que aparecem em suas telas escuras têm pouco, quase nada, do clima sombrio de Trakl, ou do noturno solitário de Goeldi, pois são noites de outra natureza, contêm uma energia latente, como as noites dos cafés de Paris do pós-guerra, repletos de conversas. . 
Fig.44

sem titulo, 1997,

esmalte sintético, emulsão óleo acrílico sobre tela, $210 \times 90 \mathrm{~cm}$

coleção particular
Fig.43

sem titulo, 1987,

óleo sobre tela, $90 \times 155 \mathrm{~cm}$

coleção particular 
Fig. 45

sem titulo, 1997,

Fig.46
alhe de uma área de tela com esmalte sintético

ético, emulsão óleo acrílico $\mathrm{cm}$ coleção do artista 
Fig.48

Sem título (2004)

Óleo e colagem sobre tela $240 x$

$90 \mathrm{~cm}$

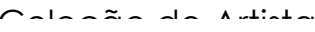

Fig.47

Em torno de H.O, (1998)

Instalação no Centro de Arte Hélio Oiticica

Seda papel e acrílica sobre parede 600 × $400 \mathrm{~cm}$

Coleção do Artista
Fig.49pintura relevo (2006)

esmalte e acrílica sobre madeira recortada e tela $85 \times 95 \times 15 \mathrm{~cm}$

Coleção do Artista 


\section{Do preto ao negro}

Eu farei um poema sobre o puro nada: Ele não falará de mim nem de quaisquer outras pessoas, Nem de amor nem de juventude,

Nem de outra coisa

Eu o fiz dormindo sobre um cavalo. Meu poema está feito, não sei sobre o quê;

Eu o passarei àquele

Que o passará a qualquer outro Além, na direção de Anjou

Para que me passe, de seu cofre, a contra-chave

Guilherme $I X^{261}$

Pierre Soulages, desde o início de sua trajetória como pintor, em 1946, explora deliberadamente as possibilidades da cor preta para extrair-lhe a luz. Costuma trabalhar à noite, sob lâmpadas elétricas, no silêncio. Um dos motivos dessa escolha é ter controle sobre a iluminação que, por ser artificial, pode ser mantida constante durante a jornada. "Não devemos nos esquecer que Van Gogh pintou telas maravilhosas à noite com velas fixadas na ponta de seu chapéu," disse em uma entrevista. Mas essa escolha pode significar algo a mais. Talvez seja exatamente a possível relação entre a cor eleita pelo pintor e o mundo noturno, um dos fatores que constroem a obra. Soulages disse que aquilo "que acontece dentro de você à noite é de uma ordem diferente do que a de lucidez." 262

O pintor associa a origem de sua poética à sua infância, ao início do interesse pela abstração. Ao prazer que teve ao ver, através da janela da sala na qual fazia a lição de casa, uma mancha de piche no muro do outro lado da 
rua. "Uma espécie de enorme borrão de cor preta, provavelmente vestígio deixado pela broxa de um operário que asfaltava a rua"263. Uma nódoa que existia enquanto forma. Dinamizada tanto pela irregularidade do material quanto pela direção dada pela marca do instrumento. Reparou nas relações da cor preta com a textura do muro. Percebeu "a viscosidade do piche, mas também o vigor da projeção, o esbatimento causado pela verticalidade da parede e pela ação da gravidade, também a fusão com o grão da pedra."264. Relatou sua frustração, ao ver certo dia, no lugar da mancha, a imagem de uma galinha. Essa figura não Ihe interessava. Satisfez-se somente no momento no qual a imagem voltou a ser a mancha, quando ele se aproximou do muro. Ao contrário de Leonardo da Vinci, que recomendava extrair imagens dos relevos de um muro, o jovem queria ver somente as relações criadas pelo manchado 265 .

Depois, na adolescência, ao observar a reprodução de uma aguada de Rembrandt, interessou-se mais pelas relações entre os golpes do pincel e a trama do papel, entre as diversas intensidades de preto da tinta e o branco, do que pela figura da mulher. ${ }^{266}$ Já, no pós-guerra, encantou-se com os vitrais da Gare de Lyon maculados com breu, após o processo de impermeabilização dos caixilhos ${ }^{267}$.

Soulages sempre trabalhou o jogo entre a luz e a escuridão de modo não figurativo. Conforme declarou:

"Desde o início eu pratiquei uma pintura que abandonou a imagem, e que jamais considerei como uma linguagem (no sentido de que uma linguagem transmite um significado). Nem imagem nem linguagem. Em 1948, escrevi no catálogo de uma exposição que 'a pintura é uma organização de formas e cores sobre a qual se fazem desfazem o sentido que se the emprestou'..268 
Ou seja, é pintura é entendida como um objeto material, feito por alguém e destinado a um espectador, que é "um interprete necessário para que o trabalho se torne obra de arte." ${ }^{269}$ Mas esse objeto material não visa a passar uma mensagem, não deve comunicar nem deve ser entendido como a expressão do mundo interior do pintor. Recusa-se a carregar qualquer coisa de anedótico ou psicológico. Não é uma declaração pessoal nem um depoimento. Além disso, pintar precede qualquer tipo de reflexão. "É o que eu faço, o que me mostra o que eu procuro"270, réplica da famosa frase de Picasso "Eu não procuro, eu acho". Soulages não busca algo que já conhece a priori, mas descobre o que está procurando enquanto faz a obra. A teoria não deveria jamais anteceder a prática, por outro lado não está apartada, faz parte implícita do ato de $\operatorname{pintar}^{271}$. Ainda, para o pintor, a arte não deveria ser depoimento, conforme afirmou: "Um artista não deve testemunhar sua época, ele faz parte dela"272. Para Soulages, a pintura é um objeto poético que permite, a quem a vir, viver de uma maneira intensa. ${ }^{273}$

Esse pensamento, que perpassa toda a sua carreira de mais de 50 anos de pintura, reflete questões postas na Paris do pós-guerra. No local e momento do início de sua carreira, a conjuntura apontava para a crise da hegemonia européia nas artes, ou seja, a descrença de que a arte fosse um predicado europeu. A cidade estava destruída e escura, conforme relatou Eduardo Sued. Reverberavam em todo o meio cultural as idéias colocadas pelas "filosofias da crise", das quais se destaca o existencialismo de Jean-Paul Sartre. Conforme explicou o crítico Giulio Carlo Argan, naquele momento à arte não tocava ser discurso nem relação. A disseminação de que a prática poética imperava sobre a teoria sugeria que a arte poderia ser justificada exclusivamente por uma 
intencionalidade. Ultrapassando a linguagem - que sempre alude a um conceito de relação com o mundo - restava, além da indiscutível "realidade da existência", somente o que era singular, inexplicável e não relativo. Portanto, o artista existia pelo fato de fazer: não pronunciava o que queria ou tinha de fazer, pois, o sentido desse fazer deveria ser dado pelo mundo. Visto que existir era a única coisa permitida, fazer-se existir, independentemente de "certo ou errado, supõe realizar na arte um tipo de existência autêntica negado à média social." 274

Segundo Soulages, naquele momento:

"Após o nazismo e a guerra que todos nós tínhamos
experimentado, eu não me sentia atraído pelos jogos das
experiências formalistas, nunca pratiquei o cubismo nem abstração
geométrica. As pesquisas de laboratório não me interessavam. Meu
caminho foi mais simples. Eu pintava possuído de uma premência,
uma necessidade que superava esses tipos de exercícios."

Ainda segundo o pensamento do artista, a obra tem vida própria e existe somente devido à tripla relação entre a coisa em si, o pintor que a criou e o observador que a receberá. Soulages, freqüente leitor de poesia, compara a prática pictórica à qualidade enigmática do poema citado na abertura desse capítulo. E o mais relevante é que ele consegue dar forma a esse pensamento. Suas pinturas referem, aludem a um enigma que a imaginação sente, mas o racional não traduz. Ou seja, as telas deixam escapar que possuem algum significado oculto, sem jamais precisarem qual é.

Esse é exatamente o diferencial e a grande dificuldade da análise da obra de Soulages. Como disse o filósofo francês Clément Rosset:

"Papel difícil realmente o do comentador, que reconhece entre mil uma tela de Soulages, mas fracassa em definir sua originalidade. Salvo recorrendo a tautologia (Uma tela de Soulages se reconhece pelo fato de que é uma tela de Soulages), ou uma metáfora 
geralmente tão menos arriscada quanto esclarecedora (Uma tela de Soulages se reconhece pelo fato que ela evoca um objeto $X$ que evoca por sua vez uma tela de Soulages)"276

As telas ainda que parecidas são todas diferentes. Categoricamente abstratas não são pinturas hostis à intervenção do observador. Podem ser contempladas, tornando-se uma experiência estética. Há perenemente um segredo a ser revelado, nada pode ser decifrado a priori. Provocam, ao mesmo tempo, um encantamento que se renova a cada vez, e uma frustração pela impossibilidade de se elucidar a charada desprovida de enunciado. As telas conjugam elementos aparentemente antagônicos: as trevas, por um lado, e a luz, por outro.

Ao longo de sua carreira poderemos identificar quadros pretos e quadros negros. Uma das características marcantes na trajetória de Soulages é a pesquisa constante com a paleta reduzida, os pretos e formas abstratas. $\mathrm{O}$ pintor sempre desenvolveu seus próprios instrumentos, pois repudiava as técnicas da pintura tradicional com suas técnicas e "os pequenos pincéis luxuosos destinados aos artistas pintores"277 Optou por usar escovas, vassouras, broxas, trinchas, espátulas, raspadores, sarrafos de madeira. Ele adapta, para seu ofício, objetos como facas utilizadas por apicultores para cortar favos, ferramental de marcenaria e curtume. Constrói pincéis que chegam a oitenta centímetros de largura. Enfim, utensílios diversos, cada um deles usado com uma finalidade específica. Alguns são escolhidos para espalhar o material, outros para criar ranhuras, veios, listas, e existem aqueles usados para alisar e nivelar a superfície ${ }^{278}$.

Coerente com a opção pela abstração, ele não atribui significados externos à pintura ao intitular sua obra com palavras estranhas à natureza da 
própria obra. Portanto um título é "pintura", se for pintura, seguido das dimensões físicas (altura x largura) e da data de execução. O título, sem a mediação, sem a intrusão da linguagem, elemento reduzido a uma informação circunstancial, especifica as condições materiais e insere a obra numa cronologia. Significa que a obra feita de certa maneira em um dado momento por ele.

No início da carreira ele criou pinturas como Goudron sur Verre 45,5 $x$ 45,5 1948-1.(fig.50) Nessas obras, cuja massa negra está sob a face vítrea, estão as questões que têm sido perseguidas pelo artista ao longo de seu percurso: uma superfície escura que rebate a claridade incidente e cria um campo luminoso. Desde o início ele optou por uma paleta bastante restrita, da qual o preto já fazia parte. A restrição é um dos meios de fazer com que um pintor aguce a percepção de determinada cor, seja mais sensível as mínimas variações. Em sua paleta, usava cores mais rebaixadas, não em sua máxima saturação.

Vale a pena apontar para o caráter inédito dessa obra. Soulages a pintou antes de Franz Kline ${ }^{279}$ começar a fazer suas obras em preto e branco. Mas, com a mudança do centro artístico para Nova lorque, após o final da II Guerra Mundial, é comum atribuírem ao americano a inauguração desse tipo de abstração.

Soulages usou extrato de nogueira, material mais fluido que cria tons muito escuros, sobre tela, como a Pintura 193,4 x 129,1cm 1948-1949.(fig.51) A tensão entre o fundo branco e as linhas escuras, que parecem pretas, é a 
tônica da tela. Até 1956, o pintor francês criou pinturas que exploravam o contraste desse pigmento escuro contra o fundo claro.

Nos anos seguintes, até os anos 1970, ele fazia com que as cores surgissem sob o óleo preto, nas áreas que eram raspadas. O preto encobria e revelava as vezes tons azuis, outras vezes vermelhos ou verdes ou amarelos. Mas, em cada tela aparecia geralmente uma única cor além da massa preta e do branco da tela. Faixas horizontais, verticais e diagonais criavam a composição. Algumas vezes somente pequenas partes do fundo colorido apareciam, como se fossem frestas entreabertas. A outra cor era coadjuvante, vinha para dialogar com o preto. Coadjuvante indispensável que devia provocar tensão no preto para gerar a luz. O pintor francês Raul Dufy disse que Soulages havia compreendido "que é a pintura a óleo: é o jogo de opacidades e de transparências". ${ }^{280}$ Mas para Soulages não era somente isso. Além da transparência e da opacidade, a pintura era também um jogo de massas, de veladuras, de brilhos, de texturas, de contrastes.

Empregava espátulas largas, criadas por ele mesmo, para depositar e arrastar a tinta, como na Pintura129,5×88,6cm,22 de maio de 1959 (fig.52). A cor preta foi espalhada e raspada e fez surgir matizes ocre-avermelhados sob o preto, entre os espaços escuros. O fundo branco aparece deliberadamente, para criar luz pela oposição entre o preto e o branco. A superfície está ocupada por gestos largos e definidos que formam faixas predominantemente horizontais. O preto transita entre o opaco e o transparente. Expõe e estica sutilmente o ocre avermelhado que surge subjacente às vastas e densas espatuladas. A tela pode ser vista num só golpe, e o contraste entre as áreas brancas, as coloridas e as pretas constrói o quadro. Como em outras obras 
feitas nesse período, o artista inicialmente aplicava um fundo vermelho-demarte em faixas da parte superior de uma tela, comprada já preparada. Logo em seguida, espalhava na tela uma pasta preta espessa, criava faixas horizontais com suas largas espátulas, depois ele arrancava parte da tinta, repassava e retirava de forma a deixar o fundo aparecer e se misturar com o preto, por fim ele aplicava em certas áreas um verniz. ${ }^{281}$ Soulages construía o quadro tanto pela justaposição quanto pela superposição desses campos cromáticos. O preto, no primeiro caso trabalhava a intensidade da claridade, que era ampliada por contraste; e no segundo, agia sobre a saturação das cores, que era filtrada e controlada por ele. Criava-se assim uma ambigüidade entre a superfície e uma ilusão de profundidade provocada pela variação de valor luminoso.

Soulages pintou uma série na qual usava somente tinta à óleo preta sobre a tela branca, na década de 1970. Certa noite, em janeiro de 1979, após um turno inteiro trabalhando e retrabalhando uma tela: passava uma pasta de tinta preta, raspava-a, passava mais uma vez, retirava novamente, ele foi deitar-se. Após horas, quando voltou ao ateliê para investigar o que havia feito, deparouse com uma tela cujas relações cromáticas não se baseavam mais no contraste fixo entre uma cor e o preto, ou entre o preto e branco, ou entre claro e escuro, mas em relações que saíam de um único pigmento preto. Um sentimento de novidade, de ter descoberto uma coisa nova, preencheu-0. ${ }^{282}$ Ele havia conseguido um campo luminoso todo feito com tinta preta.

A partir de então, por mais vinte anos, ele passou a criar telas recobertas por espessa camada de tinta negra. Soulages trabalhava com uma massa de tinta aplicada sobre a tela. Usava uma mistura de tinta à óleo preto-de-marfim, 
com resinas e, para permitir a secagem do óleo dentro na massa, adicionava um secante à base de chumbo ${ }^{283}$.

Ele trabalhava com a tela na horizontal. Aplicava a massa. Passava suas escovas e pincéis com mais ou menos pressão, para deixar marcas mais ou menos profundas. Raspava a superfície. Deslizava o sarrafo ou a espátula para deixá-la sem marcas, lisa. Assim, ele criava variações de textura da massa, com partes riscadas com marca das ferramentas e outras alisadas por espátulas ou sarrafos. Pode-se associar o procedimento de Soulages à criação de uma escultura em baixo relevo: frisa de argila trabalhada por adição e remoção de material. Na massa espessa de cor formam-se, pela ação das ferramentas do pintor, sulcos e proeminências. Mas a pintura não está pronta, para analisar o resultado de sua labuta, ele colocava-a na vertical, pois ela se completa somente com a ação luminosa. Após observá-la, se fosse necessário, deitaria a tela novamente para ser retrabalhada.

Essas pinturas de Soulages não se encaixam na definição superfície flatbed de Leo Steinberg. Não podemos dizer que a superfície pintada é o análogo de "processos operacionais" ou funcionará "como um recorte de material impresso" ou é um objeto "fabricado pelo homem e termina exatamente na superfície pigmentada". Por outro lado, o plano do quadro "não é o análogo de uma experiência visual da natureza".284

A tela completar-se-á somente ativada pela luz que, ao chegar na superfície brilhante com muitas estrias, rebate e volta para o ambiente. Cada sulco, cada aresta, cada plano, será campo de aterrissagem e arremesso dos raios luminosos em direção a quem observa a pintura. 
O negro dessas telas personifica a frase de Goethe: "As cores são ações e paixões da luz."285 Somente poderá ser entendido enquanto fenômeno cromático vivenciado por um sujeito, a partir do olho, órgão vivo e ativo. Mas, esse negro não se restringe àquilo que o poeta definiu por "cor fisiológica", ou seja, pertencente ao olho e dependente da "capacidade de agir e reagir" do órgão. A obra exige o embate corporal do observador. O "corpo vidente e visível" proposto por Merleau Ponty, cuja movimentação no mundo somada à visão "acende a centelha do sensciente-sensível" que resulta no conhecimento fenomenológico no ser no mundo. ${ }^{286}$

A variação no relevo retorna uma luz em constante mutação para o observador, dependendo do ponto de vista que ele a olha. As telas são cuidadosamente compostas para que as variações da textura criem as variações desejadas de valor. As pinturas possuem um ritmo, que é ao mesmo tempo seu coração e sua estrutura. Elas pulsam. A organização depende da variação material, da orientação dos veios e do eventual contraste com áreas lisas. "Superfícies suaves contrastam com cristas, rupturas e silêncios; um ritmo". ${ }^{287}$ As obras se recusam a serem apreendidas imediatamente, rejeitam a estagnação. Propõem sim uma nova visão a cada instante. As obras não convidam o espectador para ver o dinamismo, mas inserem-no na experiência, fazem-no vivenciar o ritmo. A tela ganha vida quando o observador caminha da direita para a esquerda, ou da esquerda para direita e vê as áreas cambiarem de cor e luminosidade, percebe a cadência da mudança. A tela funciona de qualquer ponto que é olhada. Não existe um centro, o olhar percorre toda a superfície, a tela é um todo ou infinitos pontos dispersos pela superfície. Inexiste a oposição figura-fundo. Áreas acendem outras apagam. Umas 
clareiam outras escurecem. Continuamente se alteram e se renovam. As pinturas vivem o presente, pois elas se fazem e se refazem a cada momento em que são olhadas.

Pintura completamente escura, ainda que intensamente brilhante. Quem se movimenta defronte a tela verá a superfície tornar-se refletor luminoso. 0 campo negro de Soulages difere daquele pintado por Sued. Não funciona à maneira de um espelho nem possui textura irregular. A luz invade o espaço no qual o espectador está e se apresenta de formas diferentes. Áreas luminosas se alteram com áreas sombrias. Surgem pretos, negros, cinzas, toda a espécie de cores, inclusive o prata. A superfície da tela passa a guardar uma gama infinita de possibilidades de imagens coloridas. Veremos azuis, se for de dia, e a tela encontrar-se defronte a uma janela aberta para um céu límpido. A tela tornar-se-á verde, se for refletida a cor das folhagens. Terá tons avermelhados, se for iluminada por lâmpadas incandescentes. Devolverá distorcidas as cores das roupas de quem lhe passa ao largo. É difícil acreditar que foram feitas com um único pigmento preto. A iluminação dos quadros é um fator importante para que a obra possa ser vista. Soulages gosta de colaborar pessoalmente com a organização de exposições de suas obras. Desse modo ele pode definir a disposição das obras, a circulação e a fontes de luminosidade, os parâmetros necessários à fruição.

O pintor elenca entre suas obras favoritas: as aguadas de Rembrandt, pinturas de Ticiano, Courbet, Velásquez, Franz Hals, Goya, Manet e Van Gogh. Mestres, que de alguma forma lidaram com o preto. É válido dizer que negro pintado por Soulages é herdeiro das pinturas de Frans Hals, o homem dos 27 pretos diferentes, como dizia Van Gogh. Do modo aparentemente rápido que 
Hals aplicava a tinta, que deixava indícios do fazer pictórico. Mas é também herdeiro da saia do Portrait de Nina de Callias de Manet, em cujos rastros largos do pincel, que marcam a tinta depositada em zig e zag, a luz brinca. Soulages ampliou a pincelada, deixou-a ainda mais evidente que seus antecessores, para originar esses campos de luz. Mas anulou o gesto, a marca do trabalho não é expressão de um estado psicológico do autor, mas a criação de uma superfície ativada e refletora.

Esse trabalho de Soulages traz um tratamento inédito para a luz. Ele não lança mão de sombreados para indicá-la. Ele não registra a ação dela sobre a natureza como fizeram os impressionistas. Mas ele consegue com o negro, o efeito que moisacos bizantinos conseguiam com o ouro: fazer a luz trabalhar e inundar o ambiente. Na realidade a invenção de Soulages reside no fato dele ter alterado a relação da espacialidade. Ou seja, se a luz parece emanar da superfície negra, ela sai da própria tela, se projeta à frente. O espaço deixou de ser uma virtualidade dentro do quadro, como ocorria quando, desde 0 Renascimento, usava-se a perspectiva linear. Por outro lado, não se restringe mais ao plano do quadro, como ocorre em quadros modernistas nos quais as relações cromáticas mantêm a superfície estática. Mas o espaço se mantém na frente da tela, se projeta para o lugar no qual está o espectador.

Soulages recobre totalmente a superfície com tinta preta, que sob ação da iluminação magnetiza o espectador num campo luminoso silencioso e negro, profundo. A pulsação ocorre pelo movimento entre a ausência e presença da luz, que aparece ou se esconde e, de alguma maneira, também é a alternância entre a presença e a ausência do sujeito que observa, que se volta sobre si mesmo e reflete. 
Uma obra, que mesmo numa era da reprodução técnica e da difusão da imagem, resiste a ser capturada e traduzida. Mantém sua singularidade e originalidade. A cada ponto há uma imagem distinta e única da superfície que muda conforme a incidência da luz ambiente e da movimentação do espectador. Devido a esta característica dinâmica, a fotografia jamais consegue dar conta da obra, pois acaba congelando-a numa única situação. $O$ instantâneo oferece uma imagem da tela com uma única distribuição de claro e escuro, não pode representá-la. A reprodução fotográfica em vez de deixar a luz livre, cambiante, a mantém aprisionada, e não da conta da espacialidade criada pela cor. O espaço cromático fica reduzido ao plano, efeito contrário daquele que ocorre com as telas de Manet que, quando fotografadas, aparentam ter maior volumetria.

Soulages definiu o negro dessas obras como "além-do-negro"288.

"Além-do-negro" significa: a luz refletida para lá do negro, transmutada pelo negro.

Além-do-negro": um negro que ao cessar de existir, torna-se um emissor de luz, luz secreta.

Além-do-negro" um campo mental outro que aquele do negro monocromático."288

Entre 1979 e 1999, Soulages criou 250 quadros "além-do-negro", entre outras pinturas. Foram vinte anos, nos quais o pintor fez conviver este pigmento preto com a lona. Nas pinturas inteiramente negras, criou uma diversidade dentro de um mesmo processo, nos quais intercala áreas com texturas variadas. Todas são tão semelhantes, mas tão desiguais. E cada uma é um campo cambiante conforme a movimentação do expectador. Desse conjunto, podem-se distinguir alguns tipos principais de composições. 
Polípticos que opõe superfícies lisas e superfícies nervuradas. Por exemplo, Pintura $324 \times 362 \mathrm{~cm}, 1985$, Políptico C (fig.53) constituída por quatro telas horizontais de $81 \times 362 \mathrm{~cm}$ empilhadas. Cada um desses elementos possui faixas oblíquas voltadas para a direita. A alternância entre liso e o estriado, as diferenças nas grossuras das faixas e a variação leve das inclinações criam um ritmo suave.

Há também polípticos cujos elementos são completamente ranhurados, como Pintura $290 \times 654$ fevereiro-março de 1992 (fig.54). Cinco elementos cujas superfícies estão preenchidas por listras horizontais e paralelas, mas com pequenas variações nas espessuras e espaçamento. Uma tela que, ao mesmo tempo em que dá uma ilusão de homogeneidade, revela as diferenças.

Soulages alternou a produção de telas com um único pigmento preto, com telas nas quais adicionava mais um matiz. Na maioria dessas telas, a segunda cor escolhida foi o azul. Isso, segundo Soulages, começou por acaso, quando ele vislumbrou reflexos azulados numa tela pintada exclusivamente com o pigmento preto. A partir de então ele passou a misturar pigmento azul à sua massa de tinta ${ }^{290}$. Em outras telas ele passava um preparado acrílico azul, antes de começar a pintar com a tinta à óleo preta. $\mathrm{O}$ azul surge sob o negro, por raspagem. Tem-se, assim, uma tela além-do-negro que tem reflexos azulados conforme a incidência luminosa. Soulages ata o azul ao além-donegro para reforçar a transmutação do negro em luz. O ambiente natural é banhado de azul, o ar que nos rodeia torna azuladas as coisas. $\mathrm{O}$ azul, dessa forma, ao ser colocado na tela, cria uma continuidade entre a entre o negro e a luz refletida. Essa relação física de associação natural entre essas duas cores pode provocar emoções: "A aproximação entre o negro e o azul sempre tem 
algo de bastante sensual, liberta certa volúpia ${ }^{291 ",}$ declarou Soulages. O pintor joga com o negro liso ou rajado e as estrias donde emerge o azul intenso. Uma cor realça e ilumina a outra. Em Pintura 222x222cm, 24 de janeiro de 1990 (fig.55), o azul aparece na parte inferior da tela, devido à raspagem da tinta preta. "Negro do qual surge a cor, isto é, a cor coberta e então desnudada, que emerge da tela e é excitada pelo o negro". ${ }^{292}$

A grande invenção "além-do-negro" - telas com negro intenso que gera luz e invade o ambiente, obras tão surpreendentes que faz com que as pessoas creiam que a partir do momento inaugural, em 1979, Soulages tenha feito exclusivamente esse tipo de obra - não pode eclipsar o fato do pintor jamais ter deixado de experimentar novas soluções para iluminar a partir da escuridão. "Se você olhar para a minha pintura, em sua diversidade, a sua seqüência não parece uma fatalidade, mas sim o exercício da liberdade" ${ }^{293}$, disse Soulages.

Soulages deixa o elemento central do tríptico recoberto uniformemente com um preparado vinílico preto-de-marte, normalmente usado como base que iria receber a densa tinta a óleo, na Pintura 220×324cm, 12 de janeiro de 1996 (fig.56). O preto-de-marte é avermelhado, mais quente, e o preto-de-marfim azulado, mais frio. A tela central, ao contrario das outras duas, é opaca. Não possui as estrias e relevos que jogam com a iluminação. Funciona como um sorvedouro de luz, em vez de refletor. Os raios luminosos não retornam, pois foram dragados pela superfície. Entre duas superfícies além-do-negro, o monocromo preto funciona como um abismo e ao mesmo tempo barreira para o olhar. 
Depois de 1999, o branco da tela retornou a ser visível. O pintor voltou a usar um material que já havia experimentado, na década de 1970. Retomou a tinta acrílica, por ser mais fluida e permitir maior agilidade na pintura. As áreas pintadas com o acrílico, como conseqüência, deixam de ser "além-do-negro", são pretas devido a maior opacidade da tinta. A luz pictórica aparece pelo contraste existente com o branco, que agora, diferentemente das telas da década de 1950, atravessa a tela de ponta a ponta na horizontal. Surge intensificada devido às irregularidades entre as áreas brancas e pretas, pela existência de manchas, ou marcas, ou acidentes nas fronteiras entre as duas cores. Cria uma ambigüidade: a pintura pode ser tanto uma tela branca sobre um fundo preto, quanto uma pintura preta sobre um fundo branco. Essas telas conservam algumas das características primordiais das pinturas além-donegro, a falta de um centro focal único, a dispersão por toda a superfície, a ausência da oposição figura-fundo. A irregularidade das faixas cria uma instabilidade da luz pictórica, que apesar de ser de uma natureza diferente, remete a sensação provocada pelas telas dos 20 anos anteriores. Pintura 243×181cm, 26 de junho de 1999 (fig.57), um tríptico pintado com tinta acrílica, as faixas pretas foram criadas por um método que parece carimbo, Soulages usou uma ferramenta especial, uma broxa forrada com um pano, que após mergulhada na tinta, era apoiada na tela. Essa ação era repetida pelo comprimento do quadro. A faixa foi criada pela superposição das diversas "carimbadas". O conjunto forma uma sucessão de grandes faixas pretas horizontais de ponta a ponta da tela, separadas por estreitas listras brancas irregulares. As anomalias no entrelaçamento das listras pretas e brancas, somadas ao forte contraste entre os dois valores cromáticos, faz com que a 
composição cintile. Provocam uma vibração que impede o olhar de encontrar um descanso. Forçam-no a se movimentar pela tela de forma errática, sem guarida. Percebe-se uma luz difundida em todo o espaço pictórico da tela. E as faixas metamorfoseiam-se perante o caminhar e o olhar do espectador.

Após 2004, Soulages retorna aos quadros que trabalham com a textura, mas usa uma matéria acetinada. Troca a pasta à óleo dos quadros feitos entre 1979 e 1999 por uma pasta oriunda de uma mistura de resinas acrílicas que, por secarem mais rapidamente, não apresentam o risco do craquelê que podia ocorrer no lento processo de secagem do óleo. Além disso, é possível trabalhar a tinta com várias consistências diferentes, conseqüentemente, permite grande variação de efeitos. A espessura da massa pode ser mais grossa, isso implica que as variações dos relevos podem ser maiores. Nos sulcos mais profundos, além dos reflexos, são as sombras que passam a interferir e alterar a luminosidade do negro. Em muitas dessas obras ele deixa áreas maiores lisas, recortadas por sulcos profundos, como Pintura 181x81cm, 19 de maio de 2006. A natureza da luz que emana da superfície é diferente daquela obtida com o óleo, é mais amena. O jogo luminoso se faz nos veios profundos, escurecidos pelas sombras, e nas arestas que se tornam alumiadas. Rasgos cintilantes surgem no meio da penumbra.

Há, também, um conjunto de outras telas, nas quais Soulages passa a empregar, além da massa acrílica acetinada, uma tinta que, criada a partir do mesmo pigmento, é completamente opaca. Produz dessa forma uma oposição entre áreas que dragam a luz e aquelas que a rebatem. 
Vale lembrar que, para o pintor, a luz, mais que a cor, exerce parte importante na ativação sensorial. A busca da coexistência entre a luz e a escuridão, ou melhor, a geração de luz a partir da escuridão é a força motriz da obra. Essa busca incessante faz com que surjam novas maneiras de alcançar o objetivo, conforme revelou Soulages, em relação a seu processo: "Eu organizo a luz, que nasce na, e através da, pintura. E então há sempre coisas imprevistas que abrem possibilidades novas e mais interessantes que aquilo que eu tinha a princípio em mente.” 294

Criação poética de Soulages não é o produto de uma teoria pré-existente ou de uma exploração sistemática de determinada questão pictórica. Mas sim o ato o radicalmente livre e constantemente renovado de um pintor em seu desejo de pintar. Um homem que parece ter reconhecido, nas primeiras experimentações com pintura na infância - quando surpreendeu sua irmã ao lançar mão da tinta preta, para criar uma paisagem com neve, pois queria recuperar a característica ofuscante da neve ao realçar o branco do papel pelo contraste com o preto - que a relação entre o escuro e a claridade direciona sua prática artística. E, desde então, tem continuado a encarar e confrontar o pigmento preto, com ou sem o branco, diariamente em sua produção artística a procura da luz, para criar obras tanto pretas quanto negras. 
Fig 51

Pintura 193,4 x 129,1cm 1948-1949.

Extrato de nogueira sobre tela

Museum of Modern Art- Nova

lorque

Fig 50

Goudron sur Verre 45,5 x 45,5 1948-1

Piche sobre vidro

Museu de Arte de Saint-Etienne
Fig 52

Pintura $129,5 \times 88,6 \mathrm{~cm}, 22$ de maio de 1959.

Óleo sobre tela

Museu de Arte Contemporânea - USP 
Fig 53

Pintura 324 × 362 cm, 1985, Políptico C.

Óleo sobre tela Museu Nacional de Arte Moderna de Paris
Fig 54

Pintura $290 \times 654$ fevereiro-março de 1992.

Óleo sobre tela

Elementos de $290 \times 130$ justapostos Museu d'Art Moderne Ville de Paris 82 
Fig 55

Pintura 222x222cm, 24 de janeiro de 1990.

Óleo sobre tela

Coleção Particular

Fig 56

Pintura 220×324cm, 12 de janeiro de 1996.

Óleo sobre tela

Coleção Particular 
Fig 58

Pintura $181 \times 81 \mathrm{~cm}, 19$ de maio de 2006..

Óleo sobre tela

Coleção Particular

\section{Fig 57}

Pintura $243 \times 181 \mathrm{~cm}, 26$ de junho de

1999.

Óleo sobre tela

Coleção Particular 
Notas 


\section{Prefácio}

${ }^{1}$ GOETHE, J.W Doutrina das cores (trad. Marco Giannotti) São Paulo: Nova Alexandria, 1996, p. 52

2 PASTOUREAU, M. Le petit livre dês couleurs. Paris: Éditions Du Panama, 2005, p. 96.

${ }^{3}$ Atrabílis é um substantivo feminino que significa o humor imaginário ou bílis preta, que se julgava será causa da melancolia. In: Novo Aurélio Século XXI ,Rio de Janeiro, Nova Fronteira, 1999.

${ }^{4}$ Com o desenho, além das convenções utilizadas pela perspectiva linear, pode-se dar ilusão de profundidade pela variação da dimensão das figuras, pelo uso de linhas diagonais, pelo posicionamento das figuras na tela, por sobreposição etc.

${ }^{5}$ CARNEIRO. M. Depoimento in SALZSTEIN, S. (org.) Diálogos com Iberê Camargo. São Paulo: Cosac Naify, 2003, p. 29.

\section{Preto Pigmento}

${ }^{6}$ VIGOTSKY, L. Psicologia da Arte. São Paulo: Martins Fontes, 2001.

${ }^{7}$ Entrevista realizada pela Autora em 16/6/2007.

${ }^{8}$ Para que camadas pudessem ser pintadas umas sobre as outras, mantendo simultaneamente a transparência e opacidade, além de garantir a secagem correta das camadas,

Lefranc\&Bourgeois criou uma tinta que combinava tinta à óleo com um medium emulsionante, que incluía resina Dammar. A pintura está no Museu de Arte Moderna de Paris.

${ }^{9}$ HAVEL, M. La technique du tableau. 2 ed Paris: Dessain \& Tolra, 1979.

${ }^{10}$ CLOTTES, J. Chauvet Cave, The Art of earliest times, Salt Lake City: The University of Utah Press, 2003, p. 44,112.

${ }^{11}$ DELLAMARE, F. Color the story of Dyes and Pigments, Nova lorque: Harry Adams, 2000 p.20- 21.

${ }^{12}$ Realgar: mineral monolítico, sulfeto de arsênio. In: Novo Aurélio Século XXI, op.cit..

${ }^{13}$ Auripigmentum em latim, orpiment em inglês, derivado do arsênico.

${ }^{14}$ Jarosita: mineral hexagonal, sulfato de potássio e ferro. In: Novo Aurélio Século XXI, op.cit..

${ }^{15}$ Alguns autores tentam traçar paralelos com a fatura dos vasos gregos nas suas diversas fases. Criam relações com a variação da representação da figura humana nas famosas cerâmicas de "figuras pretas sobre fundo vermelho" e "figuras vermelhas sobre fundo preto". Mas a técnica da cerâmica é diferente da técnica das outras pinturas. A cerâmica é levada três vezes ao forno. O preto é obtido durante a queima. Por isso, a cerâmica não será mencionada.

Sobre esse assunto ver SCHAUS, Gerald P. The Beginning of Greek Polychrome Painting The Journal of Hellenic Studies, Vol. 108. (1988), p. 107-117 http://links.jstor.org/sici?sici=00754269\%281988\%29108\%3C107\%3ATBOGPP\%3E2.0.CO\%3B2-Y acesso em 26/6/2007.

${ }^{16}$ Diversos estudiosos rebatem a veracidade dessa paleta. Afirmam que essa era uma preferência de Plínio, pois em sua época, o gosto popular da pintura decorativa apreciava as cores berrantes. Mas essa discussão está fora do escopo desse estudo.

${ }^{17}$ Não existe vestígio de seu uso em pinturas por não ser aplicável em afrescos.

${ }^{18}$ Vermelhão: Sulfato vermelho de mercúrio pulverizado.In Novo Aurélio Século XXI, op.cit..

${ }^{19}$ MERRIFIELD,M. Original Treatises, dating from the XV to XVIII centuries, The arts of Painting London John Murray, 1849, p. cxviii.

${ }^{20}$ CENNINI,C. Tratato della Pittura, Roma:Saiviucci,1821, p. 30-31.

${ }^{21}$ Mas, Cennini dá uma receita para fabricá-lo: 
"Pegue uma lâmpada repleta de óleo de linhaça, e coloque-a sob uma forma de assar, a chama deve ficar a us dois ou três dedos abaixo da forma, para que a fumaça que sai da chama a alcance; colete um pouco da fumaça, espere um pouco, leve a forma e raspe a fumaça, que é o pigmento para um papel." Ibid. p. 22.

${ }^{22}$ VAN GOGH, V. The complete letters of Vincent van Gogh: with reproductions of all the drawings in the correspondence Greenwich: New York Graphic Society, 1959 ,Carta 629, v.III, 259.

${ }^{23}$ Dr. Ella Hendriks, chefe do departamento de conservação do Museu Van Gogh em Amsterdã, passou essa informação por email do dia 20/2/2008. Consta de CARLYLE, L., The Artist's Assistant, Archetype Publication, 2001, p. 206-7 e p. 229, nota. 1

${ }^{24}$ Fornecido no mercado pela empresa Kremer Pigmente.

${ }^{25}$ A empresa Gamblin Artists Colors fornece um preto cromático feito pela mistura de Quinacridone Red and Phthalo Emerald.

\section{Preto e a sombra}

${ }^{26}$ GOETHE, J.W Doutrina das cores (trad. Marco Giannotti), São Paulo: Nova Alexandria, 1996, p. 35.

${ }^{27}$ Plínio aponta tanto Filocles, o egípcio quanto Cleanthes de Corinto como os inventores desse contorno com linha. Um processo semelhante está associado aos primórdios da escultura, a filha de um oleiro fixa a imagem do amado, que partirá, ao contornar sua sombra na parede. Butades, o pai da moça, penalizado com o sofrimento da filha, preenche com argila o local antes ocupado pela sombra. O perfil, assim executado, é posteriormente queimado junto às outras cerâmicas Segundo essa descrição, a sombra real acompanha o corpo que se ausenta, enquanto a silhueta desenhada no muro imortaliza a presença na forma de uma imagem. Aprisiona o momento e o torna perene

Segundo Plínio, Aridices, o Corinto, e Telephanes, de Sicíon foram os primeiros a praticar o monocromo, sombreavam o interior das figuras com linhas

${ }^{28}$ ALBERTI, L.B., Da pintura, Campinas: Editora da Unicamp, 1999, p. 129-131.

29 "Divide-se a pintura em três partes; essa divisão nós a tiramos da própria natureza. Como a pintura se dedica a representar as coisas vistas, procuremos notar como são vistas as coisas. Em primeiro lugar, ao ver uma coisa, dizemos que ela ocupa um lugar. Neste ponto, o pintor, descrevendo um espaço terá de percorrer uma orla com linha é circunscrição. Logo em seguida, olhando esse espaço, fica sabendo que muitas superfícies desse corpo visto convêm entre si, então o artista marcando-as em seus lugares, dirá que está fazendo uma composição. Por último discernimos mais distintamente as cores e as qualidades das superfícies e como toda a diferença se origina da luz, com propriedade podemos chamar sua representação de recepção de luzes". Ibid., p. 108

${ }^{30}$ Nero, bianco, benché questi non sono messi fra' colori, perché l'uno è tenebre, l'altro è luce, cioè l'uno è privazione e l'altro è generativo, io non li voglio per questo lasciare indietro, perché in pittura sono i principali, conciossiaché la pittura sia composta d'ombre e di lumi, cioè di chiaro e oscuro. " (preto e o ,brancoa, mesmo que eles não sejam colocados entre as cores, pois um é trevas, outro é luz, isto é um é privação e outro geração, pois na pintura são as principais cores, considerando-se que a pintura seja composta de sombras e luzes, isto é de claro e escuro) DA VINCI, L., Trattado della Pittura, Storia dell't̀alia, Einaudi:Edição de referência 1924 , p. 119.

${ }^{31}$ Sobre esse assunto ver HARVEY, John Men in Black Chicago: The University of Chicago Press, 1996 p. 41-92.

${ }^{32}$ GOETHE,J..W, op.cit., p. 141.

${ }^{33}$ Goethe valorizava as cores e em um parágrafo escreveu que o uso das bases escuras nas pinturas tem "conseqüências bem negativas". Pois, "somente luzes que foram destacadas permanecem claras, e percebem-se apenas manchas luminosas sobre o quadro; as pinturas da escola bolonhesa e de Caravaggio bastam como exemplo".lbid., p. 152. 
${ }^{34}$ GOETHE, J.W Doutrina das cores (trad. Marco Giannotti), São Paulo: Nova Alexandria, 1996, p. 68.

${ }^{35}$ Ibid., p. 85-86

${ }^{36}$ Ibid., p. 54.

${ }^{37}$ Ibid., p. 102.

${ }^{38}$ Ibid., p. 66.

Michel Eugène Chevreul (1786-1889), questionado pelo diretor da fábrica real de tapetes Gobelins de Paris sobre as razões do preto perder intensidade ao lado de sombras circundantes em azul ou violeta, publicou De la loi du contraste simultané des couleurs et de l'assortiment des object colorés, um estudo importante sobre os contrastes simultâneos .

39 Ibid.,p. 145.

${ }^{40}$ Sobre esse assunto ver BAXANDALL, M Os quadros e as idéias: Uma dama tomando Chá, de Chardin em BAXANDALL, M. Padrões de Intenção. A explicação histórica dos quadros São Paulo: Companhia das Letras, 2006 pp.120-156

${ }^{41}$ GREEnBERG, C., Collage, 1959, in GREENBERG, C , Art and Culture,. Boston: Beacon Press, 1961, p. 70-83

42 "The cleanly and simply contoured solid black shapes on which Gris relied so much in these paintings represent fossilized shadows and fossilized patches of shading. All the value gradations are summed up. in a single, ultimate value of flat, opaque black--a black that becomes a color as sonorous and pure as any spectrum color and that confers upon the silhouettes it fills an even greater weight than is possessed by the lighter-hued forms which these silhouettes are supposed to shade" Ibid.

${ }^{43}$ A origem do Quadrado preto sobre fundo branco situa-se em 1913, época na qual Malévitch fez o figurino e a cenografia da ópera futurista A Vitória sobre o Sol , ( libreto de Kruchenikh, música de Matiouchine e prólogo de Khlebnikov). A ópera tratava da tentativa de prender o Sol. E rebatia toda a idéia de transcendência associada à luz. A escuridão era reveladora, a luz era o ilusório. No segundo ato, um avião caía em cena. Havia um eclipse do Sol, a escuridão encobrindo o mundo dos objetos e das ilusões. As origens do Suprematismo remontam aos estudos para o cenário dessa ópera, nos quais Malévitch desenhava o palco, de forma esquematizada. A forma escolhida em todos os esboços era o quadrado, trabalhado com as cores branca e preta. Alguns continham desenhos cubo-futuristas, mas um era sintetizado num quadrado dividido em dois triângulos, um preto e o outro branco. Podia ser interpretado como a eclipse parcial, que levaria a total ocultação dos objetos no Quadrado preto sobre fundo branco.

${ }^{44}$ MALEVICH, K.S., Essays on art 1815-1930, vol.I Londres: Rapp. Whiting Limited, 1968, p. 38.

${ }^{45}$ GREENBERG, C., Pintura à americana in FERREIRA, G (org.) Clement Greenberg e 0 debate crítico Rio de Janeiro: Jorge Zahar, 1997, p. 84- 85.

${ }^{46}$ SYLVESTER, D.: Newman II in SYLVESTER, D.N, Sobre a arte moderna, São Paulo: Cosac Naify, 2007, p. 447.

\section{Preto como cor}

${ }^{47}$ VALERY, P., The triumph of Manet, in VALERY, P., Degas Manet Morisot. Nova lorque: Pantheon Books. 1960, p. 112.

${ }^{48}$ Ver SCHAPIRO, M., Impressionismo: reflexões e impressões, São Paulo: Cosac Naify, 2002, p. $80-81$.

${ }^{49}$ lbid., p. 230.

${ }^{50}$ Ver CLARK T.J., A pintura da vida moderna Paris na Arte de Manet e de Seus Seguidores. São Paulo: Companhia das Letras, 2004. 
${ }^{51}$ CLARK, T.J., Modernism, postmodernism and steam, October, no 100, Spring 2002, Cambridge, Massachusetts: The MIT Press, 2002 p. 154-174.

${ }^{52}$ Citado em COURTHION[ed], Manet Raconté par lui memé et pare sés amis, Geneva, 1953, p. 134-136.

${ }^{53}$ TASSINARI, A., Passado e presente na arte moderna, Novos Estudos n.ำ 4, abril de 1984.

${ }^{54}$ Ver STEINBERG, L., Outros Critérios: Confrontos com a arte do século XX(trad. Célia Euvaldo), São Paulo: Cosac Naify, 2008,p. 97-108.

${ }^{55}$ Michel Foucault interessou-se por Manet, entre o final da década de 1960 e início de 1970. Escreveria um livro intitulado Le Noir el Le Couleur. O livro jamais foi escrito, mas Foucault proferiu seminários em Milão (1967), Florença e Tóquio (1970) e Tunísia (1971). Foucault analisou treze telas de Manet $A$ transcrição do último seminário foi transformada num livro: FOUCAULT, M., La Peinture de Manet, Paris: Editions du Seuil, 2004.

${ }^{56} \mathrm{Em}$ francês: tableau-objet. Pode ter reinventado, pois na idade média as pinturas não tentavam ser janelas para o mundo, mas eram objetos.

${ }^{57}$ Manet escreveu, para Zacharie Astruc em 1865, que descoberta das obras de Velásquez era que mais o havia impressionado. Em sua opinião, somente isso, mesmo que isoladamente, já valia a viagem à Espanha. vide WILSON-BAREAU, J. (Ed.), Manet by Himself, 1992,p. 36.

${ }^{58}$ WILSON-BAREAU, Op.cit., p. 34.

Steinberg nos lembra que nas obras de Velásquez o modo de pintar, controntar os impastos com áreas mais lavadas, reforça, a presença material da pintura.Ver STEINBERG, L., Outros Critérios: Confrontos com a arte do século XX, São Paulo: Cosac Naify, 2008 p. 106

${ }^{59}$ NÉRET, G., Manet,Londres:Taschen, 2003. p. 11

${ }^{60}$ Manet fez essa afirmação em uma lição de pintura para Eva Gonzáles. WILSON-BAREAU, Juliet (Editor), Manet by Himself Boston: Chartwell Books, 1992, p. 52

${ }^{61}$ Segundo o próprio Manet, ele havia pintado o retrato de Desboutin "com tanta paixão quanto Baudelaire", e mesmo que não pudesse afirmar que o quadro sintetizasse "toda uma época", certamente ele havia pintado "a personalidade mais extraordinária das redondezas." Registrado por Antonin Proust em 1878. WILSON-BAREAU, Op.cit, p. 183

${ }^{62}$ Baudelaire nos apresentou esse modo de vestir

"Vede bem que a roupa negra e a sobrecasaca têm não apenas sua beleza política, que é a expressão da igualdade universal, mas também sua beleza poética, que é a expressão da alma pública; um imenso desfile de coveiros, coveiros políticos, coveiros apaixonados, coveiros burgueses. Todos nós celebramos algum enterro."

BAUDELAIRE, Charles. Salão de 1846. In: BAUDELAIRE, Charles Poesia e prosa. Rio de Janeiro: Nova Aguilar, 1995, p. 729.

63," "noir d'um bout a láutre comme lê portrait d'um charbonnier...,". In Museu de Arte de São Paulo, Enciclopédia dos Museus São Paulo: Melhoramentos 1973, p. 66

${ }^{64}$ WILSON-BAREAU, Op.cit., 1992, p. 261

${ }^{65}$ Manet já expusera a hipocrisia da burguesia francesa, do final do século XIX, em relação ao sexo, ao expor sua Olímpia. Ela tem uma fita preta colocada no pescoço que servia para separar a cabeça do corpo. Criando um abismo entre o racional e o sensorial. Algumas questões poderiam ser levantadas pela sobreposição entre essa sombra preta masculina e a figura feminina. Quais eram os papeis esperados para os homens e as mulheres na sociedade moderna? Quais eram as relações de poder, opressão?

${ }^{66}$ FOUCAULT, Op. cit.,p. 40-43

${ }^{67}$ Para ampliar o assunto sobre sombras vide: STOICHITA, Victor A short History of the shadow Londres Reaktion Books. 1999

${ }^{68} \mathrm{~A}$ beleza entre o rosa e o preto está presente nos versos de Baudelaire, dedicados a outro quadro de Manet, Lola de Valencia 
Entre tant de beautés que partout on peut voir,/ Je comprends bien, amis, que le désir balance: / Mais on voit scintiller en Lola de Valence/ Le charme inattendu d'un bijou rose et noir.

${ }^{69}$ Manet, referindo-se a seu quadro "O bebedor de absinto" afirmou que a crítica francesa não havia compreendido sua opção de pintar com a "mesma técnica naïve de Velásquez" um personagem parisiense comum. Ele ainda arriscou que crítica talvez compreendesse se 0 retratado fosse um tipo espanhol. Essa declaração foi feita a Antonin Proust, entre $1858 \mathrm{e}$ 1860. WILSON-BAREAU, Juliet (Editor), Manet by Himself Boston: Chartwell Books, 1992, p.97

${ }^{70}$ VALERY, P. The triumph of Manet in VALERY, P Degas Manet Moriso Nova lorque:

Pantheon Books. 1960 p. 112..

${ }^{71}$ Ibid. p. 113

${ }^{72}$ WILSON-BAREAU, Op.cit, p. 26

"...I gave up. the Idea of getting anything out of antiquity. But I learnt a great deal on my trip. to Brazil. I spent endless nights looking at the play of light and shade in the ship's wake. And in daytime, from the upper deck, I would keep. my eyes on the horizon. That's how I learnt how to capture a sky."

\section{Preto Interior}

${ }^{73}$ STEINBERG, Leo Jasper Johns: Os sete primeiros anos de sua arte in STEINBERG, Leo Outros Critérios confrontos com a arte do século $X X$ trad. Célia Euvaldo) São Paulo Cosac Naify 2008 p. $42-43$

${ }^{74}$ VAN GOGH, Vincent THE COMPLETE letters of Vincent van Gogh: with reproductions of all the drawings in the correspondence Greenwich: New York Graphics., 1959 Carta 351a, vol. II, p. 254.

${ }^{75}$ Ibid.

${ }^{76}$ Ibid., Carta 371 vol. II, p. 294.

${ }^{77}$ Ibid..

${ }^{78}$ Tom-rompido é a interpenetração de cores complementares. Tom-inteiro é uma cor saturada, plena, sem mistura com branco, preto ou outra cor.

${ }^{79}$ lbid.

${ }^{80}$ Ibid., Carta 370, vol. II, p. 292.

${ }^{81}$ Ibid., Carta 429, vol. II, p. 426.

${ }^{82}$ Ibid., Carta 428, vol. II, p. 422.

${ }^{83}$ Ibid., Carta 370, vol. II, p. 292.

${ }^{84}$ Ibid., Carta 428, vol. II, p. 422.

${ }^{85}$ Ibid., Carta 426, vol. II, p. 416.

${ }^{86}$ Ibid., Carta 428, vol. II, p. 422.

${ }^{87}$ Ibid., Carta 426, vol. II, p. 416.

${ }^{88}$ Ibid., Carta 428, vol. II, p. 422.

${ }^{89}$ Ibid., Carta n 442 vol. II, p. 463.

${ }^{90}$ Ibid., Carta 520, vol. III, pg 6

91 "O que Seurat está fazendo? Eu não ousaria mostrar-Ihe os estudos anteriores, mas gostaria que ele visse os girassóis e os cabarés e os jardins. Freqüentemente penso no método dele, apesar de não segui-lo de maneira alguma. Mas ele é um colorista original, assim como Signac, num grau diferente. O pontilhado deles é uma descoberta nova, e em todos os eventos 
eu gosto deles muito, Mas eu pessoalmente, para dizer-Ihe a verdade, estou voltando mais para o que eu estava procurando antes de ter ido a Paris."

VAN GOGH, Vincent THE COMPLETE letters of Vincent van Gogh: with reproductions of all the drawings in the correspondence Greenwich: New York Graphics., 1959 Carta 539 vol. III, p. 39

${ }^{92}$ SCHAPIRO, Meyer Vincent Van Gogh. New York Harry N Abrams 1950 p. 31

${ }^{93}$ VAN GOGH, Op.cit., Carta B 6 a Emile Bernard. Vol. III, p. 485.

${ }^{94}$ Ibid.

${ }^{95}$ lbid.

${ }^{96}$ Ibid., Carta B 3 a Emile Bernard. vol. III, p. 478.

${ }^{97}$ MERLEAU-PONTY, Maurice : A Linguagem indireta e as vozes do silêncio in: MERLEAUPONTY, Maurice. O Olho e o Espírito. São Paulo: Cosac Naify, 2004 p.83

${ }^{98}$ Ibid., Carta B 21 a Emile Bernard, , vol. III, p. 521.

${ }^{99}$ AURIER Albert The Isolated Ones: Vincent van Gogh G.- Mercure de France, Janeiro, 1890

${ }^{100}$ VAN GOGH, Op.cit., Carta 625 vol. III, p. 251

101 Ibid., Carta 596, vol. III, p. 184.

102 Ibid., Carta a Albert Aurier 626a, vol. III, p. 256.

${ }^{103}$ SCHAPIRO, Meyer Sobre um quadro de Van Gogh in SCHAPIRO, Meyer A Arte moderna séculos XIX e XX, Edusp, 1979 p. 133-146

${ }^{104}$ Ibid., Carta 133, vol. I, p. 193.

105 Ibid., Carta 649, vol. III, p. 295.

${ }^{106}$ Ibid., Carta 325, vol. II, p. 141.

107 Ibid., Carta 331, vol. II, p. 160.

${ }^{108}$ Ibid., Carta 534, vol. III, p. 30.

Tartarin, um herói burlesco de romances de Alphonse Daudet (1840-1847), é muito citado nas correspondências de Van Gogh. Seja por suas aventuras em locais distantes, seja por sua capacidade de imaginação, seja por sua índole boa.

${ }^{109}$ Ibid., Carta 508, vol. II, p. 607.

${ }^{110}$ Ibid., Carta 535, vol. III, p. 32.

${ }^{111}$ SCHAPIRO, Op.cit., p. 140

\section{Preto e Superfície}

112 "C'est le noir qui fait faire aux couleurs le grand écart. II s'agit donc d'une lumière au-delà de la lumière, de son acclimatation et qu'elle permette un renouveau, une source [...] Mais le noir est à la fois notion abstraite, et par là dangereuse à mesure qu'elle prend le large - et donnée concrète. Le noir concret (si j'ose dire) peut être brûlure ou caresse, éclaboussement. Sa présence met, par choc en retour, la peinture tout à construire de couleurs une synthèse de lumière et d'espace (les couleurs étant celles sur la toile et non dans le tube)

${ }^{113}$ MATISSE, Henri. Escritos e reflexões sobre a arte. São Paulo: Cosac Naify, 2007. p. 226, Nota 65

${ }^{114}$ Ibid., p. 57

${ }^{115}$ Ibid., p. 226 n 65

${ }^{116}$ Hokusai publicou um livro sobre o uso apropriado das cores em 1848,

ver GAGE, Jonh "Color and Meaning. Art, science and Symbolism Bekerley:University of California Press 1999 p. 229 e 302 n5 
${ }^{117}$ MATISSE, Op.cit., p. 226

${ }^{118}$ GAGE, Op. cit., p. 228-240

${ }^{119}$ MATISSE, Op. cit., p. 181

${ }^{120}$ Ibid., p. 140

${ }^{121}$ Ibid., p. 91 n 40

122 Ibid., p. 140

${ }^{123}$ Ibid., p. 225.

${ }^{124}$ Ibid., p.153

${ }^{125}$ Ibid., p. 362

${ }^{126}$ Ibid., p. 219

${ }^{127}$ Há várias referências a essa relação, entre elas:

NERET, Gilles Matisse, Koln, London, Paris:Taschen 2006, p. 79-85

ESSERS, Volkmar Henry Matisse 1869-1954 Koln :Taschen 1993 p. 44

BARR, Alfred Matisse his art and his public, p. 178

${ }^{128}$ Apud NERET, Op.cit.,p. 83.

${ }^{129}$ MATISSE, Op.cit., p.126.

${ }^{130}$ Ibid., p.126 n 80

${ }^{131}$ lbid., p. 96

${ }^{132}$ GOETHE, J.W Doutrina das cores (trad. Marco Giannotti), São Paulo: Nova Alexandria, 1996, p. 52

${ }^{133}$ Na primeira vez que visitou essa casa, percebeu, a abertura da porta de entrada revelou "um hall escuro e vazio" que a fez lembrar do quadro Porta-Janela aberta a Colliouire (1914). Para chegar ao quarto iluminado de Matisse, percorreu uma sucessão de salas na penumbra com venezianas e portas serradas, nas quais os objetos se revelavam sutilmente, após os olhos terem se habituado à escuridão. Isso a fazia lembrar o hábito provinciano de proteger os objetos e móveis das ações dos raios solares.

Ver GILOT, Françoise Matisse e Picasso, São Paulo Editora Siciliano, 1992, p. 31, p. 97 ${ }^{134}$ Ibid., p.102

${ }^{135}$ GREENBERG, Clement Henri Matisse ,Nova lorque Acquarela Galleries INC , $1973 \mathrm{~s} / \mathrm{p}$

${ }^{136} \mathrm{O}$ texto Collage mostra, por um viés formal, as diferenças entre as fases do cubismo e a diferença entre as obras de Picasso, Braque e Gris. Farei uma simplificação para mostrar como ele via o preto no cubismo e porque afirmou ter sido influencia para Matisse.

GREENBERG, Clement, "Collage" (1959), in GREENBERG, Clement Art and Culture Boston: Beacon Press, 1961, p. 70-83.

${ }^{137}$ MATISSE, Henri. Op.cit. p. 125

${ }^{138}$ Ibid. p. 141

139 Ibid. p. 222.

140 Ibid. p. 50.

141 lbid. p. 50.

${ }^{142}$ BARR, Alfred Matisse his art and his public Nova York: Museum of Modern Art, 1951 p. 178

${ }^{143}$ Ver explicação em MONOD-FONTAINE, Isabelle. Matisse Ouvres de Henri Matisse (18691954) Collections Du Musse National D'art Moderne. pp. 38-41 
${ }^{144}$ BARR, Alfred Op.cit., 1951 p.188.

${ }^{145}$ MATISSE, Henri. Escritos e reflexões sobre arte São Paulo: Cosac Naify 2007 p. 226 n 66.

${ }^{146}$ Tanto o cartão postal quanto a carta foram enviados a Charles Camoin in FLAM, Jack. Matisse, the man and his art, 1869-1918 London: Thames and Hudson. 1986 p. 397.

Vale notar que Matisse falava da estrutura de colocação das figuras no plano pictórico, e não do divisionismo cromático.

${ }^{147}$ Matisse perguntara a Aragon, a respeito de $A$ Mulher de Véu (La Femme a la Voilette) um quadro pintado, por volta de 1942, "Você não acha que é um pouco direto?Um pouco Manet?" in MATISSE, Henri. Op.cit., p. 214 nota51

${ }^{148}$ FLAM, Jack. Op.cit., p. 397

${ }^{149}$ Está certo que o vidro colocado sobre o quadro cria um efeito de espelho e reduz a profundidade cromática a uma espacialidade especular. Esses reflexos foram abstraídos nessa análise.

${ }^{150}$ ARAGON, Henri Matisse um romance apud NERET, Giles Matisse Taschen 2006 p. 80

${ }^{151}$ REINHARDT,Ad Significant art 1910-1966 apud FLAM, Jack. Op.cit. p. 394

${ }^{152}$ MATISSE, Op.cit. p. 83

${ }^{153}$ GILOT, Françoise Matisse e Picasso , São Paulo Editora Siciliano, 1992, p. 98

${ }^{154}$ MATISSE, Op.cit. p. 226

${ }^{155}$ BOIS, Yve-Alan On Matisse: The Blinding.for leo Steinberg October, vol 68 MIT Press:1994 p. 106

${ }^{156}$ MONOD-FONTAINE, Isabelle. Matisse Ouvres de Henri Matisse (1869-1954) Collections Du Musse National D'art Moderne. p. 84

${ }^{157}$ GREENBERG, Clement Matisse, New York Pocket Books INC, $1953 \mathrm{~s} / \mathrm{p}$

\section{O corpo do preto}

${ }^{158}$ Entrevista feita por Antonio Hohlfeldt, publicada no Caderno Especial do Correio do Povo, 26/7/1981, p. 9.

${ }^{159}$ BRITO, Ronaldo: Trágico Moderno in BRITO, Ronaldo. Experiência crítica. São Paulo Cosac Naify 2005, p. 231.

${ }^{160}$ CAMARGO, Iberê Gaveta dos Guardados p. 135

${ }^{161}$ Há um pequeno desenho "A beira do Jaquari” (1941), no qual a mata foi derrubada e há troncos cortados deitados no solo.

${ }^{162}$ CAMARGO, Iberê Gaveta dos Guardados p. 136.

${ }^{163}$ VENANCIO Filho, Paulo Iberê Camargo, Desassossego do mundo Rio de Janeiro, Silvia Roesler: Instituto Cultural Axis:2001, p. 14

${ }^{164}$ Depoimento de Iberê a Evelin Berg in BERG Evelin [et alli] Iberê Camargo Rio de Janeiro: Funarte INAP. MARGS 1985 p. 15

${ }^{165}$ VENANCIO Filho, Paulo Op.cit., p. 14

${ }^{166}$ Edmundo Cardoso in BERG Evelin Op.cit., p. 36.

${ }^{167}$ Mário Carneiro in BERG Evelin Op.cit., p. 41

${ }^{168}$ Carneiro, Mário Depoimento in SALZTEIN, Sônia (org.) Diálogos com Iberê Camargo São Paulo: Cosac Naify. 2003, p. 27

${ }^{169}$ Carneiro, Mário Depoimento in SALZTEIN, Sônia (org.) Diálogos com lberê Camargo São Paulo Cosac\&Naify 2003 p. 27. 
${ }^{170}$ Iberê in LAGNADO, Lisette Conversações com Iberê Camargo São Paulo: lluminuras 1994, p. 22

${ }^{171}$ Entrevista realizada por Carlos e Marcos André Martins in Catálogo A gravura de lberê Camargo. MARGS, 1991

172 Iberê Camargo analisava também as soluções dos desenhos e das gravuras. Observou por exemplo que nos desenhos de Filipino Lippi o lápis era trabalhado com leveza, não se encontrava um "negro violento ou exagerado." Em outra página ele reforça sua opinião: "não esquecer que nunca há um negro exagerado". Anotava as variações de intensidade de preto nas gravuras de Goya, de Dürer etc. Prestava atenção na qualidade do papel e tipo de técnicas e materiais empregados. Há também várias anotações sobre técnicas de pintura e de gravura, com as opiniões dos instrutores.

${ }^{173}$ CAMARGO, Iberê e Carneiro, Mario Iberê Camargo, Mario Carneiro Correspondência Rio de Janeiro: Casa da Palavra/ Centro de Arte Helio Oiticica/ Rio Arte: 1999 p. 47

${ }^{174}$ Depoimento de Iberê Camargo em entrevista manuscrita a Mônica Zielinsky, sem data in http://iberecamargo.uol.com.br/content/exposicoes/texto monica.asp, acesso em 27/03/2007.

${ }^{175}$ CARNEIRO, Mário Depoimento in SALZTEIN, Sônia (org.) Op.cit. p. 29

${ }^{176}$ Depoimento dado por lberê Camargo ao Correio da Manhã, em 16 de maio de 1954

177 Declaração da pintora brasileira, Djanira da Mota e Silva (1914-1979), que também encabeçou o movimento ao Diário de Notícias de 18/04/1954, in BERG Evelin [et alli] Iberê Camargo Rio de Janeiro: Funarte INAP. MARGS 1985 p. 20.

lberê dava muita importância à qualidade das tintas, nesse período pesquisa através de amigos a viabilidade das tintas européias Linel, Lefranc, Rembrandt, mas optou pelas tintas belgas Blockx.

${ }^{178}$ Contato telefônico com Mario Carneiro, dia 24/07/2007

179 Depoimento de Iberê Camargo in COTRIM, Cecília A paixão na pintura. Depoimento de Iberê Camargo a Martins, Novos Estudos n³4, novembro 1992 p. 112-113

${ }^{180}$ Iberê ainda pintou naturezas mortas, mas eram paisagens solares: "O quadro é um mundo encantado. Nele a luz não vem do sol. Poços de Caldas, 1959, a última paisagem que pintei, está mergulhada numa luz crepuscular" declarou in LAGNADO, Lisette Op.Cit.(p. 33)

${ }^{181}$ SCHAPIRO, Meyer. As maçãs de Cézanne in SCHAPIRO, Meyer A Arte moderna séculos XIX e XX, Edusp, 1979 p 61-63.

${ }^{182}$ Vale a pena observar um esboço para uma dessas composições, no qual vemos que o trabalho de lberê não era instintivo e ingênuo. Ele usava e pesquisava artifícios de composição. Um desenho seu revela que ele, nesse momento, recorria também à proporção áurea. Foi preciso compreender as regras de composição e fatura artística para poder esgarçá-las.

${ }^{183}$ Cf. depoimento de Iberê Camargo a Anna Letycia de quadros, em "Só há um salão: o Salão Moderno" para todos, 1958 in ZIELINSKY, Mônica Iberê Camargo Catálogo raisonné: volume 1/ gravuras São Paulo: Cosac Naify, 2006, p. 62

${ }^{184}$ Cf. contato telefônico com Mario Carneiro, dia 24/07/2007

${ }^{185}$ Ver o artigo "Oswaldo Goeldi" que Iberê escreveu para o Correio do Povo, Porto Alegre 19/02/1961 in LAGNADO, Lisette Op.cit., p. 136-137.

${ }^{186}$ Cf. entrevista a Carlos Martins e Marcos André Martins in ZIELINSKY, Mônica Op.cit., p. 80

${ }^{187}$ ZIELINSKY, Mônica Op.cit. 2006 p. 67

${ }^{188}$ Carta de lberê a Mário Carneiro, de 8/11/1957 in CAMARGO, Iberê e CARNEIRO, Mario Op.cit., p. 127

${ }^{189}$ Carta de Iberê a Mário Carneiro, de 8/11/1957 in CAMARGO, Iberê e CARNEIRO, Mario Iberê Camargo, Mario Carneiro Correspondência Rio de Janeiro: Casa da Palavra/ Centro de Arte Helio Oiticica/ Rio Arte: 1999 p. 127 
${ }^{190}$ Entrevista realizada por Carlos e Marcos Andre Martins in Catálogo A gravura de lberê Camargo 1991-MARGS s/p.

Mesmo a seguinte declaração dada a Antonio Hohfeldt:

"Na verdade sou um sujeito que esteve sempre muito preocupado com a cor. Eu procuro jamais repetir uma cor, uma tonalidade em meus quadros. Ė como se enquanto escritor, estivesse sempre em busca de sinônimos. Vario a cor para evitar a monotonia. Por isso, mexo tanto em minhas telas" passa a ter sentido quando colocada no contexto da entrevista na qual Iberê está falando que a fruição de um quadro "... è como guerra e paz de Tolstoi:quando se termina de ler a obra é que se consegue realmente abrange-la no seu todo", não existe enquanto partes isoladas

Correio do povo 26/7/81 Caderno Especial p. 9

Aponto também para o seguinte trecho de entrevista de Clarice Lispector em Entrevistas

Clarice- Diga-me: até que ponto uma cor exprime, e só ela, aquilo que o pintor está sentindo? Por que exatamente o marrom, e em seu lugar o vermelho?

Iberê- Na minha opinião a cor vale em seu contexto, nas suas relações. Enquanto que uma cor isolada será fria ou quente. $\mathrm{E}$ a intensidade de sua medida é também estabelecida no confronto com outras cores.

In LISPECTOR, Clarice Entrevista com Iberê Camargo in LISPECTOR, Clarice. De corpo inteiro. São Paulo: Siciliano, 1992.

${ }^{191}$ GULLAR, Ferreira Do Fundo da matéria in SALZTEIN, Sônia (org.) Diálogos com lberê Camargo São Paulo Cosac\&Naify 2003 p. 16

${ }^{192}$ ARGAN, Giulio Carlo. Arte moderna: do iluminismo aos movimentos contemporâneos. São Paulo: Companhia das Letras, 1996. p. 505

${ }^{193}$ Carta de Iberê a Mário Carneiro, de 11/08//1957 in CAMARGO, Iberê e Carneiro, Mario Op.cit., p.122- 124

${ }^{194}$ Carta de Iberê a Mário Carneiro, de 11/08//1957 in CAMARGO, Iberê e Carneiro, Mario Iberê Camargo, Mario Carneiro Correspondência Rio de Janeiro: Casa da Palavra/ Centro de Arte Helio Oiticica/ Rio Arte: 1999 p. 123

${ }^{195}$ ARGAN, Giulio Carlo. Arte moderna: do iluminismo aos movimentos contemporâneos. São Paulo: Companhia das Letras, 1996. p. 375

${ }^{196}$ SCHAPIRO, Meyer Sobre um quadro de Van Gogh in SCHAPIRO, Meyer A Arte moderna séculos XIX e XX, Edusp, 1979 p. 140

${ }^{197}$ Ibid.

${ }^{198}$ Carta a Mário Carneiro de 8/12/1057 in CAMARGO, Iberê e Carneiro, Mario lberê Camargo, Mario Carneiro Correspondência Rio de Janeiro: Casa da Palavra/ Centro de Arte Helio Oiticica/ Rio Arte: 1999 p. 127.

${ }^{199} \mathrm{Na}$ documentação existente, freqüentemente aparece ou 1956 ou 1958 como a ano da hérnia de disco que acamou Iberê. Utilizo por referência uma carta escrita por Iberê a Mário Carneiro, em dezembro de 1957, relatando o início da doença. in CAMARGO, Iberê e Carneiro, Mario Iberê Camargo, Mario Carneiro Correspondência Rio de Janeiro: Casa da Palavra/ Centro de Arte Helio Oiticica/ Rio Arte: 1999 p. s.131-132.

${ }^{200}$ CAMARGO, Iberê e Carneiro, Mario Iberê Camargo, Mario Carneiro Correspondência Rio de Janeiro: Casa da Palavra/ Centro de Arte Helio Oiticica/ Rio Arte: 1999 p. 131

${ }^{201}$ Ibid

${ }^{202}$ Contato telefônico com Mario Carneiro, dia 24/07/2007

${ }^{203}$ Desde o início do século XX, as vanguardas artísticas anunciavam a morte da pintura. Ao buscarem a essência da pintura, ao reduzi-la a seus elementos essenciais, pintores questionam a possibilidade da sobrevivência da pintura no mundo industrial. O pintor russo Kasimir Malévitch propôs uma arte em que a imagem estava livre das amarras da figuração. 
Pintou seu quadrado preto sobre o fundo branco, e iniciou a tarefa de luto da pintura, juntamente com Piet Mondrian, segundo Yves Alain Bois:

"é o questionamento sobre a possibilidade de ainda existir pintura que está no início do fim, e é esse início do fim que tem sido nossa história, a saber, o que estamos acostumados a chamar de modernismo. De fato, toda a aventura do modernismo, especialmente da pintura abstrata que pode ser tomada como seu emblema -, não teria funcionado sem um mito apocalíptico"

BOIS, Yve-Alain Pintura a tarefa de luto.(Trad. Taís Ribeiro) in Ars, Revista de Pós Graduação do Departamento de Artes Visuais, São Paulo, SP, v. 7, 2006, p. 98

$204 \mathrm{O}$ movimento influenciou parte da arte no Brasil. Alguns dos artistas que abraçaram ou tangenciaram o informalismo, também empregaram o preto em suas obras. Mas eram cores que surgiam como marcas ou manchas amorfas. O gesto da arte caligráfica japonesa influenciou o preto empastado na abstração de Manabu Mabe ).Já na pintura de Tomie Ohtake, o preto surgia como um universo cosmológico, um buraco negro.

${ }^{205}$ LAGNADO, Lisette Conversações com Iberê Camargo São Paulo: lluminuras 1994, p. 20

${ }^{206}$ Por exemplo, Lúcio Fontana rasgava as tela em suas Concepções espaciais. Robert Rauchemberg apresentava suas telas nas quais objetos mundanos eram agregados fisicamente à superfície pictórica. O italiano Alberto Burri apresentou trabalhos nos quais o evento pictórico dava-se pela transformação da matéria: a combustão de plásticos e madeiras, a oxidação dos ferros, os esgarçados nos sacos.

207 Depoimento de Iberê Camargo COTRIM, Cecília A paixão na pintura. Depoimento de lberê Camargo a Martins, Novos Estudos n³4, novembro 1992 p. 108-109

${ }^{208}$ Ibid., p. 115.

${ }^{209}$ CATTANI, Icleia Borsa Figuras e lugares nas pinturas de Iberê in SALZTEIN, Sônia (org.) Diálogos com Iberê Camargo São Paulo Cosac\&Naify 2003 p. 86

${ }^{210}$ PEDROSA Mário Ecos da Bienal - pintores brasileiros, Jornal do Brasil, 16 de janeiro de 1961.

${ }^{211}$ Entrevista de lberê a Carlos Martins e Marcos André Martins 11/06/1990 apud ZIELINSKY, Mônica lberê Camargo Catálogo raisonné: volume 1/ gravuras São Paulo: Cosac Naify, 2006 p. 94

${ }^{212}$ ZIELINSKY, Mônica Iberê Camargo Catálogo raisonné: volume 1/ gravuras São Paulo: Cosac Naify, 2006 p. 95

${ }^{213}$ Carta não datada, sem destinatário e local, na qual lberê agradecia a parabenização por um prêmio recebido.

${ }^{214}$ Entrevista a Antonio Hohfeldt publicada no Correio do povo, caderno especial 26/7/81 p. 9

${ }^{215}$ Entrevista realizada por Carlos e Marcos Andre Martins in Catalogo A gravura de lberê Camargo 1991-MARGS

${ }^{216}$, Empresto o termo de Merleau-Ponty, quando propõe que o olhar como uma variação da experiência tátil, em oposição à idéia de uma visão pura in MERLEAU-PONTY, Maurice $O$ visível e o invisível (Trad. José Artur Giannotti e Armando Mora d'Oliveira). São Paulo, Perspectiva. 2000

217“Só se vê o que se olha. Que seria a visão sem nenhum movimento dos olhos, e como esse movimento não confundiria se ele próprio fosse reflexo ou cego, se não tivesse suas antenas, sua clarividência, se a visão não se precedesse nele?"

MERLEAU-PONTY, Maurice: O olho e o espírito (Trad. Paulo Neves e Maria E.G.Pereira). São Paulo: Cosac Naify. 2004 p. 16

${ }^{218}$ MERLEAU-PONTY, Maurice ; A dúvida de Cézanne MERLEAU-PONTY, Op.cit p. 130-131

${ }^{219}$ Por exemplo: as experiências do neoconcretismo haviam rompido com a arte nos suportes convencionais. Hélio Oiticica já incorporara o cotidiano, o espectador e a ação em suas obras. Nos Estados Unidos, o minimalismo aderia à lógica industrial e apregoava o uso dos materiais 
industrializados, das formas simples, da seriação, para criar relações entre os espectadores e as obras. A pop. arte anexava os elementos de consumo e da cultura de massa às obras.

${ }^{220}$ Carta de lberê a San Yu Kim, 9/6/1960, na qual também está escrito: "Se permite recomendar-lhe-ei ser metódico na conquista dos meios de expressão para que o trabalho não nasça da improvisação, nem do acaso, favorável à arte, mas improdutivo na formação de um gravador"

${ }^{221}$ Iberê - caderno Mais! Folha de S.Paulo- 6/3/1994

${ }^{222}$ CAMARGO, Iberê, No andar do tempo Porto Alegre: L\&PM p. 65-74

${ }^{223}$ Visto por esse prisma, fica fácil entender a rejeição de lberê a artistas que propunham a coisificação e jogavam a arte em solo mundano

"Pode-se - as bienais e os salões estão abarrotados de sucedâneos - permanecer aquém da forma de arte. Julgar que a pintura acabou, que a escultura acabou, que a gravura acabou é confundir as possibilidades da matéria com o fenômeno de arte. (...) Então não se distingue mais a matéria da forma? A ausência de discernimento conduz à sandice e até a fogueira: hoje queima-se a poesia, amanhã o poeta"

CAMARGO, Iberê Fiel à arte 11/02/1968 in LAGNADO, Lisette Conversações com lberê Camargo São Paulo: lluminuras 1994, p. 142

${ }^{224}$ CAMARGO, Iberê texto no Correio do Povo Porto Alegre, 24/12/1969 in LAGNADO Op.cit, p. 145

${ }^{225}$ Trecho de carta escrita por lberê à Regina Silveira, no Rio de Janeiro, em 30 de junho de 1965, na qual ele também escreveu: "Estou particularmente interessado em experimentar a "Bougeois aine" no 12, cujos tubos satisfazem, pelo tamanho, minha volúpia de pintar com espessa massa de cor. Estou cansado de espremer raquíticos tubinhos, tamanho médio, importados pelos tímidos revendedores"

${ }^{226}$ Nos cadernos das anotações da viagem, entre 1948 e 1950, para Europa, lberê escreveu: "Deus criou o mundo do nada. Eu direi que Ticiano criou obras primas com quase nada. Copiando Ticiano é que posso..."

${ }^{227}$ Chula dança, música de origem portuguesa In: Novo Aurélio Século XXI, Rio de Janeiro, Nova Fronteira, 1999.

${ }^{228}$ GADAMER, Hans-Georg A Atualidade do belo. A arte como jogo, símbolo e festa. Rio de Janeiro:Tempo Brasileiro, 1985, p. 61

${ }^{229}$ Ibid., p. 63

${ }^{230} \mathrm{Em} 5$ de dezembro de 1980, Iberê e sua secretária foram agredidos em Botafogo, perto do atelier, no Rio de Janeiro. No desfecho da briga, Iberê matou o agressor com dois tiros. Ele foi preso. Julgado, como um caso de legítiva defesa, foi absolvido e solto em 30 de janeiro de 1981.

${ }^{231}$ Entrevista feita por Antonio Hohlfeldt, publicada no Caderno Especial do Correio do Povo, 26/7/1981, p. 9.

${ }^{232}$ Depoimento de Iberê Camargo in COTRIM, Cecília A paixão na pintura. Depoimento de Iberê Camargo a Martins, Novos Estudos n³4, novembro 1992 p. 116

${ }^{233}$ LAGNADO, Lisette Conversações com Iberê Camargo São Paulo: lluminuras 1994, p. 21.

${ }^{234}$ Referente à cor do chumbo. Palavra escolhida para passar, além da cor, uma idéia de peso.

${ }^{235}$ Entrevista realizada por Carlos e Marcos Andre Martins in Catálogo A gravura de lberê Camargo 1991-MARGS s/p

${ }^{236}$ Iberê respondeu, por carta a José Américo em 19/2/1968, como escolher a cor de tinta para retratar um rosto, após explicar as relações entre as cores, contar que Delacroix poderia transformar o barro numa "luminosa carnação de um corpo de mulher justapondo-lhe uma cor", recomendou a observação atenta dos retratos de grandes mestres em museus. Essa observação poderia revelar que a cor da pele, assim como a de qualquer outro objeto do 
quadro, foi aquela adotada pelo pintor. Bastaria reparar a "cor na pele arroxeada das figuras de El Greco, no amarelo quente das figuras de Rembrandt, na pele alaranjada das figuras de Rubens. A mentira é tão convincente que passa por verdade na arte." E aqui vemos como essa relação na arte se encadeou no pensamento, pois, mesmo sem estar explicitamente escrito, Iberê passou por vários artistas posteriores, entre eles, Van Gogh, Matisse e Picasso. Cuja famosa frase foi referida por Iberê. Trecho da carta encontra-se in BERG Evelin [et alli] lberê Camargo Rio de Janeiro: Funarte INAP. MARGS 1985 p. 27

${ }^{237}$ Para uma da presença ou carretéis como "motivo" na obra de lberê, ver SALZSTEIN, , Sônia Ausência de carretéis in ZIELINSKY, Mônica \& SALZSTEIN Sônia Iberê Camargo:moderno no limite 1914-1994 Porto Alegre: Fundação lberê Camargo, 2008 p. 33-48

${ }^{238}$ Entrevista realizada por Carlos e Marcos Andre Martins in Catálogo A gravura de lberê Camargo 1991-MARGS s/p.

\section{Espelho Negro}

${ }^{239}$ TRAKL,G Poemas (tradução Paulo Quintela) Porto: Oiro do dia,1980 p. 101

${ }^{240}$ SUED, Eduardo Eduardo Sued, entrevista a lleana Pradilla e Lúcia Carneiro, coleção palavra do artista. Rio de janeiro: Lacerda, 1998 , p. 19

${ }^{241}$ Ibid. p. 42

${ }^{242}$ NAVES, Rodrigo. Evidência e dissolução. In. NAVES, Rodrigo Precisão: Amilcar de Castro, Eduardo Sued, Waltercio Caldas. Rio de Janeiro: Centro Cultural Banco do Brasil, 1994. p. 65

${ }^{243}$ Sobre esse assunto ver KRAUSS, Rosalind Grids in KRAUSS The originality of the AvantGard and Other Modernist Myths Cambridge:MIT press,1997 p. 9-22

${ }^{244}$ MERLEAU-PONTY, Maurice: O olho e o espírito (Trad. Paulo Neves e Maria E.G.Pereira). São Paulo: Cosac Naify. 2004 p. 37

${ }^{245}$ FOUCAULT, Michel. Outros espaços. In: FOUCAULT, Michel. Estética: literatura e pintura, música e cinema (trad. Inês Autran Dourado Barbosa)Rio de Janeiro: Forense Universitária, 2006 p. 414-415.

${ }^{246}$ Por exemplo, Leonardo da Vinci compara a superfície da pintura àquela do espelho. E diz que o espelho deve servir de guia e tutor para os pintores. Leonardo também sugere que o pintor lance mão do espelho para, ao ver a imagem invertida de sua obra, conseguir identificar seus defeitos. DA VINCI, Leonardo Trattado della Pittura Storia dell'İtalia Einaudi:Edição de referência 1924 p. 201- 202

${ }^{247}$ As possíveis relações entre um observador, o espelho e o mundo perpassa toda a história da pintura. Por exemplo,em As meninas, Velásquez cria um jogo entre o observador e a representação, coloca o observador como modelo da pintura executada dentro do quadro.

${ }^{248}$ Há um espelho negro mais antigo. Arqueólogos acreditam, baseados nas peças encontradas até hoje, que o mais antigo espelho tenha sido feito, por volta de 6.200 A.C, em Çatal Hüyük, na planície de Anatólia, atual Turquia. Um objeto vítreo negro, uma peça polida feita de obsidiana . um mineral escuro e vítreo de origem vulcânica.

${ }^{249}$ Declaração dada a Marcela Rangel em entrevista realizada, 7/3/2005, no Atelier em Jacarépagua

Essa metáfora equivale à expressão: "um quadro bem sucedido é aquele que desaparece" usada por Sued in SUED, Op.Cit , p. 38-39

${ }^{250}$ DUARTE, Paulo Sérgio. Ato de pintura e potência cromática. In: CONDURU, Roberto; DUARTE, Paulo Sérgio. Eduardo Sued - A Experiência da pintura. Centro Cultural Banco do Brasil, 2004, p. 13

251 ARGAN, Giulio Carlo Arte Moderna São Paulo: Companhia das Letras,1996., p.269-270

${ }^{252}$ SUED, Eduardo Eduardo Sued, entrevista a lleana Pradilla e Lúcia Carneiro, coleção palavra do artista. Rio de janeiro: Lacerda, 1998 , p. 44-45

${ }^{253}$ CANONGIA, Lígia (org.) Eduardo Sued, São Paulo: Cosac Naify, 2005 p. 147 
${ }^{254}$ Entrevista realizada por mim, no ateliê de Jacarepaguá, 25 de novembro de 2008

${ }^{255}$ Cit. in WILSON-BAREAU, Juliet (Editor), Manet by Himself Boston: Chartwell Books , 1992, p. 26

${ }^{256}$ Entrevista realizada por mim, no seu ateliê de Jacarepaguá, 25 de novembro de 2008

${ }^{257}$ Idem

${ }^{258}$ Idem

${ }^{259}$ Idem

${ }^{260}$ Idem

\section{Do negro ao preto}

${ }^{261}$ Je ferai un poème sur le pur néant / II ne sera ni sur moi, ni sur quelqu'un d'autre / Ni sur l'amour, ni sur la jeunesse / Ni sur rien d'autre / Je l'ai fait en dormant sur un cheval / Mon poème est fait, je ne sais sur quoi / Je le transmettrai à celui / Qui le transmettra par quelqu'un d'autre / Là-bas vers l'Anjou / Pour qu'il me transmette de son étui la contre-clé./

Apud SOULAGES, Pierre, Image et signification, rencontres de l'École Du Louvre Paris, La documentation Française, 1984 in. ENCREVÉ, Pierre. Soulages, Le peintures 1946-2006 Paris Seuil, 2007, p. 334.

Guilherme IX (1071-1129), duque de Aquitânia e trovador

${ }^{262}$ CONNOR Russell, Au-delà du noir, Paris Alvik,2003 p. 111

${ }^{263}$ SOULAGES, Op.cit. p. 327-328

${ }^{264}$ Ibid.

265 Ibid.

${ }^{266}$ Ibid.

${ }^{267}$ RAGON, Michel Les ateliers de Soulages Paris Éditions Albin Michel 1990, p. 19-21.

${ }^{268}$ Très tôt j'ai pratiqué une peinture qui abandonnait l'image, et que je n'ai jamais considérée comme un langage (au sens où un langage transmet une signification). Ni image ni langage. En 1948 j'écrivais dans un catalogue d'exposition que "la peinture est une organisation de formes et de couleurs sur laquelle viennent se faire et se défaire les sens qu'on lui prête".

SOULAGES, Op.cit. p. 332

${ }^{269}$ SOULAGES, Pierre, Léspace dans La peinture in ENCREVÉ, Op.cit., p. 117

${ }^{270}$ Soulages cit. in ENCREVÈ, Op.cit, p. 239

${ }^{271}$ SOULAGES, Pierre "Les années 50" in Le Nouvel Observateur, 24-30 juin 1988, in site documentaire

${ }^{272}$ Soulages apud RAGON,Op.cit., p. 8

${ }^{273}$ Ibid.,.p. 9

${ }^{274}$ ARGAN, Giulio Carlo Arte Moderna São Paulo: Companhia das Letras, 1996 p. 538.

${ }^{275}$ Après le nazisme et la guerre que nous avons tous vécus, je ne me sentais pas le goût des jeux, des expériences formelles, je n'ai pas "fait" du cubisme, ni de l'art abstrait géométrique... Les recherches de laboratoire ne m'intéressaient pas. Mon chemin a été plus simple. J'ai peint poussé par un besoin, une nécessité qui passait avant ce genre d'exercices "Le procès à Soulages" entretien de Pierre Soulages avec Pierre-Michel Buraglio in journal larté, Paris, mai 1962 in site documentaire

${ }^{276}$ ROSSET, Clement O objeto Pictural. Homenagem a Pierre Soulages. Revista Gavea n 15, Rio de Janeiro, 1997

${ }^{277}$ ENCREVÈ, Pierre Soulages, Le peintures 1946-2006 Paris: Seuil, 2007, p. 255, p. 37 
${ }^{278}$ RAGON, Michel Les ateliers de Soulages Paris Éditions Albin Michel 1990, p. 84

${ }^{279}$ Franz Kline (1910-1962) era um pintor figurativo, mas em 1949 após ter visto seus esboços ampliados por um projetor, começou a desenvolver sua abstração.

${ }^{280}$ RAGON, Op.cit..p. 44.

${ }^{281}$ No final da década de 1950, Soulages encomendava sua pasta de tinta preta a um comerciante de cores, Edouard Adams ( o mesmo que criou o azul de Yves Klein (1928-1962) que a fazia mediante as especificações do artista. A composição era pigmento preto-de-marfim, óleo de linhaça cozido com litargírio (monóxido de chumbo) e o secante Flamand de Lefranc. $O$ secante Flamand de Lefranc-Bourgeois é composto de uma resina de copal de Madagascar, com forte proporção de óleo de linhaça, além de um óleo polimerizado a quente e um litargírio (monóxido de chumbo) diluídos em essência de terebintina. Comprava as telas na loja Lefebvre-Foinet. Pierre Soulages empregava então um verniz à base de resina natural (Dammar) ou sintética (Vernis Vibert, Lefranc).

Segundo Trabalho de conclusão de estudos não publicado apresentado de LA GRANDIERE, Pauline de, Technique Classique et problems contemporaines: Pierre Soulages Peinture, $114 \times$ 165 cm, 16 décembre 1959 Museé d'Art moderne La Ville de Paris. 2005, p. 23-26

282 Declaração de Soulages apud..ENCREVÈ, Op.cit, p. 217 e RAGON, Op.cit. p. 88

${ }^{283}$ ENCREVÈ, Op.cit. p. 255, 357.

${ }^{284}$ STEINBERG, Leo Outros Critérios in STEINBERG, Leo Outros Critérios confrontos com a arte do século $X X$ trad. Célia Euvaldo)São Paulo Cosac Naify 2008 p. 117-123

${ }^{285}$ GOETHE, J.W Doutrina das cores (trad. Marco Giannotti), São Paulo: Nova Alexandria, 1996 p. 13

${ }^{286}$ MERLEAU-PONTY, Maurice: O olho e o espírito (Trad. Paulo Neves e Maria E.G.Pereira). São Paulo: Cosac Naify. 2004. 18

${ }^{287}$ Soulages in JULIET, Charles, Pierre Soulages, Peintures de 1984-1986 18 de outubro a 13 de dezembro, Paris: Galerie de France, 1986 p. 9

${ }^{288}$ As telas que possuem essa características serão chamadas ao longo desse capítulo de "além-do-negro"

289 "Outrenoir" pour dire: au-delà du noir une lumière reflétée, transmutée par le noir. "Outrenoir": noir qui, cessant de l'être, devient émetteur de clarté, de lumière secrète.

"Outrenoir": un champ. mental autre que celui du monochrome noir. Entrevista a Pierre Encrevé "Les éclats du noir" Beaux-arts magazine, edição especial, 1996 in ENCREVÈ,Op.cit. p. 223.

${ }^{290}$ ENCREVÉ, Pierre Soulages L'ouvre complete Peintures III. 1979-1997.Paris Editions de Seul 1998 p. 168

291 Ibid. p. $172-173$

292 JULIET, Charles, Pierre Soulages, Peintures de 1984-1986 18 de outubro a 13 de dezembro, Paris: Galerie de France, 1986 p. 9

${ }^{293}$ Soulages apud ENCREVÈ, ( 2007) Op.cit., p. 337

${ }^{294}$ PEPPIATT, Michael, 'An Interview with Pierre Soulages', Art International, Vol. 24,,

Part 3-4, Nov./ Dec, 1980, p. 157-173. 


\section{Bibliografia}

ALBERTI, L.B Da Pintura (trad.Antonio da Silveira Mendonça). Campinas: Editora da UNICAMP, 1999.

ARGAN Giulio Carlo História da arte italiana - volume 3 De Michelangelo ao Futurismo.. São Paulo, Cosac\&Naify: 2003

ARGAN, Giulio Carlo. Arte moderna: do iluminismo aos movimentos contemporâneos.(Trad. Denise Bottmann e Federico Carotti) São Paulo: Companhia das Letras, 1996.

ARNHEIM, Rudolf. Arte e Percepção Visual. São Paulo, EDUSP, 1980

AURIER Albert The Isolated Ones: Vincent van Gogh G.- Mercure de France, Janeiro, 1890.

BARR, Alfred Matisse his art and his public Nova York: Museum of Modern Art, 1951.

BATAILLE, Georges The cradle of Humanity Prehistoric Art And Culture Nova lorque: Zone Books 2005

BAUDELAIRE, Charles Poesia e prosa. Rio de Janeiro: Nova Aguilar, 1995.

BAXANDALL, M. Padrões de Intenção. A explicação histórica dos quadros São Paulo: Companhia das Letras, 2006

BERG Evelin [et alli] Iberê Camargo Rio de Janeiro: Funarte INAP. MARGS 1985.

BOIS, Yve-Alain Pintura a tarefa de luto.(Trad. Taís Ribeiro) in Ars, Revista de Pós Graduação do Departamento de Artes Visuais, São Paulo, SP, v. 7, 2006, p. 98.

BOIS, Yve-Alain. Painting as Model. Cambridge, Massachusetts: MIT Press, 1992

BOIS, Yve-Alan On Matisse: The Blinding.for leo Steinberg October, vol 68 MIT Press:1994.

BRITO, Ronaldo \& NAVES, Rodrigo Iberê Camargo São Paulo: DBA 1994

BRITO, Ronaldo. Experiência crítica. São Paulo Cosac Naify 2005.

BRITO, Ronaldo. Neoconcretismo: vértice e ruptura do projeto construtivo brasileiro. São Paulo, Cosac \& Naify Edições, 1999.

CAMARGO, Iberê e CARNEIRO, Mario Iberê Camargo, Mario Carneiro Correspondência Rio de Janeiro: Casa da Palavra/ Centro de Arte Helio Oiticica/ Rio Arte: 1999.

CAMARGO, Iberê Gaveta dos Guardados São Paulo:EDUSP, 1998

CAMARGO, Iberê, No andar do tempo Porto Alegre: L\&PM 1988

CANONGIA, Lígia (org.) Eduardo Sued, São Paulo: Cosac Naify, 2005.

CASATI, Roberto A descoberta da Sombra, São Paulo: Cia da Letras. 2001

CENNINI,C. Tratato della Pittura, Roma:Saiviucci,1821.

CLARK T.J., A pintura da vida moderna Paris na Arte de Manet e de Seus Seguidores. São Paulo: Companhia das Letras, 2004.

CLARK, T.J., Modernism, postmodernism and steam, October, № 100, Spring 2002, Cambridge, Massachusetts: The MIT Press, 2002.

CLOTTES, J. Chauvet Cave, The Art of earliest times, Salt Lake City: The University of Utah Press, 2003.

CONDURU, Roberto; DUARTE, Paulo Sérgio. Eduardo Sued - A Experiência da pintura. Centro Cultural Banco do Brasil, 2004. 
CONNOR Russell, Au-delà du noir, Paris Alvik, :2003.

COTRIM, Cecília A paixão na pintura. Depoimento de lberê Camargo a Martins, Novos Estudos n³4, novembro 1992

COURTHION[ed], Manet Raconté par lui memé et pare sés amis, Geneva, 1953.

DA VINCI, Leonardo Trattado della Pittura Storia dell'Italia Einaudi:Edição de referência 1924

DELLAMARE, F. Color the story of Dyes and Pigments, Nova lorque: Harry Adams, 2000.

DUARTE, Paulo Sérgio. Anos 60/Transformações da arte no Brasil. Rio De janeiro: Campos Gerais, 1998

ENCREVÉ, Pierre Soulages L'ouvre complete Peintures III. 1979-1997.Paris Editions de Seul 1998.

ENCREVÈ, Pierre Soulages, Le peintures 1946-2006 Paris: Seuil, 2007.

ESSERS, Volkmar Henry Matisse 1869-1954 Koln :Taschen 1993

FABRIS, Annateresa (org.). Modernidade e o modernismo no Brasil. Campinas, Mercado de Letras, 1994 ..

FERREIRA, Carlos Eduardo Moreira(apres.) Oswaldo Goeldi, mestre visionário São Paulo: SESI, 1996

FERREIRA, G (org.) Clement Greenberg e o debate crítico Rio de Janeiro: Jorge Zahar, 1997.

FLAM, Jack. Matisse on art, Berkeley:UCLA press, 1995

FLAM, Jack. Matisse, the man and his art, 1869-1918 London: Thames and Hudson. 1986.

FOSTER, Hal.( edited) Discussions in Contemporary Culture- Number One. Seattle, EUA, Bay Press, 1987

FOUCAULT, Michel La Peinture de Manet. Paris: Editions du Seuil, 2004

FOUCAULT, Michel. Estética: literatura e pintura, música e cinema (trad. Inês Autran Dourado Barbosa)Rio de Janeiro: Forense Universitária, 2006.

FRANCASTEL, Pierre. Imagem, visão e imaginação. São Paulo: Martins Fontes, 1983

GADAMER, Hans-Georg A Atualidade do belo. A arte como jogo, símbolo e festa. Rio de Janeiro:Tempo Brasileiro, 1985.

GAGE , Jonh Color in art Penguin 2006

GAGE, John Color and Culture Practice and Meaning from Antiquity to abstraction. Berkeley: University of Califórnia Press, 1993.

GAGE, Jonh Color and Meaning. Art, science and Symbolism Bekerley:University of California Press 1999

GILOT, Françoise Matisse e Picasso, São Paulo Editora Siciliano, 1992.

GOETHE, J.W Doutrina das cores (trad. Marco Giannotti) São Paulo: Nova Alexandria, 1996.

GOMBRICH. Ernest Shadows The depiction of cast shadows in western art Londres:The National Gallery publications. 1995

GREENBERG, Clement Art and Culture Boston: Beacon Press, 1961.

GREENBERG, Clement Henri Matisse ,Nova lorque Acquarela Galleries INC , 1973 s/p

GREENBERG, Clement Matisse, New York Pocket Books INC, $1953 \mathrm{~s} / \mathrm{p}$

GREENBERG, Clement The collected essays and criticism Chicago: The University of Chicago Press, 1995 
GULLAR, Ferreira. Etapas da arte contemporânea. Do cubismo à arte neoconcreta. Rio de Janeiro, Revan, 1998.

HARVEY, John Men in Black Chicago: The University of Chicago Press, 1996.

HAVEL, M. La technique du tableau. 2 ed Paris: Dessain \& Tolra, 1979.

JULIET, Charles, Pierre Soulages, Peintures de 1984-1986 18 de outubro a 13 de dezembro, Paris: Galerie de France, 1986

KRAUSS The originality of the Avant-Gard and Other Modernist Myths Cambridge:MIT press, 1997.

KRAUSS, Rosalind E. The Originality of Avant Gard and Other Modern Myths. Cambridge, The MIT Press, 1997

LA GRANDIERE, Pauline de, Technique Classique et problems contemporaines: Pierre Soulages Peinture, $114 \times 165 \mathrm{~cm}, 16$ décembre 1959 Museé d'Art moderne La Ville de Paris. 2005.

LAGNADO, Lisette Conversações com Iberê Camargo São Paulo: lluminuras 1994.

LISPECTOR, Clarice Entrevista com Iberê Camargo in LISPECTOR, Clarice. De corpo inteiro. São Paulo: Siciliano, 1992.

LUCIE-SMITH, Eduard. Movements in Art since 1945 Issues and Concepts. Londres, Inglaterra Thames and Hudson, 1995

MALEVICH, K.S., Essays on art 1815-1930, vol.I Londres: Rapp. Whiting Limited, 1968.

MARTINS, Carlos MARTINS, Marcos Andre(org.) Catalogo A gravura de Iberê Camargo MARGS: 1991

MATISSE, Henri. Escritos e reflexões sobre a arte. São Paulo: Cosac Naify, 2007.

MERLEAU-PONTY, Maurice O visível e o invisível (Trad. José Artur Giannotti e Armando Mora d'Oliveira). São Paulo, Perspectiva. 2000

MERLEAU-PONTY, Maurice. O Olho e o Espírito. São Paulo: Cosac Naify, 2004.

MERRIFIELD,M. Original Treatises, dating from the XV to XVIII centuries, The arts of Painting London John Murray, 1849.

MILLER, Jonathan On Reflection. Londres:The National Gallery publications. 1998

MONOD-FONTAINE, Isabelle. Matisse Ouvres de Henri Matisse (1869-1954) Collections Du Musse National D'art Moderne s/d

Museu de Arte de São Paulo, Enciclopédia dos Museus São Paulo: Melhoramentos 1973.

NAVES, Rodrigo Precisão: Amilcar de Castro, Eduardo Sued, Waltercio Caldas. Rio de Janeiro: Centro Cultural Banco do Brasil, 1994

NERET, Gilles Matisse, Koln, London, Paris:Taschen 2006, p. 79-85

NÉRET, Gilles., Manet,Londres:Taschen, 2003.

Novo Aurélio Século XXI, Rio de Janeiro, Nova Fronteira, 1999.

ORDINE, Nuccio O Umbral da Sombra São Paulo Perspectiva 2006.

PASTOUREAU, Michel. Le petit livre dês couleurs. Paris: Éditions Du Panama, 2005,.

PEDROSA, Israel Da cor a Cor inexistente: Rio de Janeiro, Leo Christiano Editorial Ltda, 1999

PEDROSA, Mário. Acadêmicos e modernos; org. Otília B. Fiori Arantes. São Paulo, EDUSP, 1998, v. 3. (Textos Escolhidos III).

PENDERGRAST, Mark Mirror, Mirror A history of the human love affair with reflection, Nova lorque: Basic Books 2003.

PEPPIATT, Michael, An Interview with Pierre Soulages, Art International, Vol. 24,, 
RAGON, Michel Les ateliers de Soulages Paris Éditions Albin Michel 1990, p. 19-21.

ROSSET, Clement O objeto Pictural. Homenagem a Pierre Soulages. Revista Gávea n 15, Rio de Janeiro, 1997

SALZTEIN, Sônia (org.) Diálogos com Iberê Camargo São Paulo: Cosac Naify. 2003.

SCHAPIRO, Meyer A Arte moderna séculos XIX e XX, Edusp, 1979.

SCHAPIRO, Meyer Vincent Van Gogh. New York Harry N Abrams 1950 p. 31

SCHAPIRO, Meyer, Impressionismo: reflexões e impressões, São Paulo: Cosac Naify, 2002.

SCHNEIDER Pierre Matisse, Tout l'ouvre peint de Matisse Paris, Flammarion, 1986.

STEINBERG, L., Outros Critérios: Confrontos com a arte do século XX (trad. Célia Euvaldo), São Paulo: Cosac Naify, 2008.

STOICHITA, Victor A short History of the shadow Londres Reaktion Books. 1999

SUED, Eduardo Eduardo Sued, entrevista a lleana Pradilla e Lúcia Carneiro, coleção palavra do artista. Rio de janeiro: Lacerda, 1998.

SUED, Eduardo Eduardo Sued,pinturas 1980-1998 Rio de Janeiro Centro de Arte Hélio Oiticica, 1998

SYLVESTER, D.N., II in SYLVESTER, D.N, Sobre a arte moderna, São Paulo: Cosac Naify, 2007, p. 447.

TASSINARI, A., Passado e presente na arte moderna, Novos Estudos n.ำ 4, abril de 1984.

TRAKL,G Poemas (tradução Paulo Quintela) Porto: Oiro do dia,1980,

VALERY, Paul., The triumph of Manet, in VALERY, P., Degas Manet Morisot. Nova Iorque: Pantheon Books. 1960

VAN GOGH, V. The complete letters of Vincent van Gogh: with reproductions of all the drawings in the correspondence Greenwich: New York Graphic Society, 1959.

VENANCIO Filho, Paulo Iberê Camargo, Desassossego do mundo Rio de Janeiro, Silvia Roesler: Instituto Cultural Axis:2001.

VIGOTSKY, L. Psicologia da Arte. São Paulo: Martins Fontes, 2001.

WILCOX, Michel Blue and Yellow don't make Green Bristol: Michel Wilcox School of color, 2006 p.182-184

WILSON-BAREAU, Juliet (Editor), Manet by Himself Boston: Chartwell Books , 1992.

ZIELINSKY, Mônica Iberê Camargo Catálogo raisonné: volume 1/ gravuras São Paulo: Cosac Naify, 2006.

ZIELINSKY, Mônica \& SALZSTEIN, Sônia. Iberê Camargo:moderno no limite 1914-1994 Porto Alegre: Fundação Iberê Camargo, 2008. 
- 205 - 


\section{Anexo: Entrevista com Eduardo Sued}

As próximas páginas - nas quais estão impressas a compilação da entrevista realizada por mim, no ateliê de Jacarepaguá, 25 de novembro de 2008 - visam a incrementar as informações sobre o que fomenta a produção pictórica de Sued, em especial o uso que faz da tinta preta para criar seus pretos e seus negros. $^{295}$

\section{Pinturas pretas e negras ${ }^{296}$}

Pintura é o ambiente no qual espaços, planos, cores ,linhas, pontos, etc., se relacionam segundo uma ordem, não nominável, advinda dele mesmo e de minha própria experiência. O que ocorre num ambiente preto/negro ? Estimo que haja graus de saturação de preto, e, o de maior energia preta é o negro. Saturar um branco, isto é, torná-lo mais branco, com mais energia branca que o branco de prata,por exemplo, - o branco mais branco conhecido, nominável - é possível pela entourage. Isto é, pela presença de cores que estão a seu lado. Feito já conhecido pelos antigos pintores. Portanto, o conteúdo escuro dos pretos e dos negros também se desvanece ou se intensifica por sua vizinhança. Um branco vizinho os torna mais saturados e mais luminosos. E as tonalidades cinzas, por exemplo, menos saturados e luminosos. A saber: colocando um branco ao lado, ou em torno de um preto ele se torna mais saturado, mais preto, com mais energia escura. Dai os planos complexos de pretos e de negros no ambiente preto/negro.

Além da vizinhança, a quantidade de um preto, por exemplo, altera sua saturação: a superfície de um negro é mais negra que a superfície menor desse mesmo negro. 
Guaguin dizia que um quilo de vermelho é mais vermelho que meio quilo desse mesmo vermelho .

As diversas saturações de pretos e negros criam, portanto, em seu ambiente, planos de fortes contrastes.

\section{A questão da espacialidade.}

“Convivi com ela, na adolescência, 'pegando jacaré', na Praia do Arpoador. Esperando uma onda era invadido frontalmente por dois grandes planos - o céu e o mar - que se uniam dentro de mim.

A espacialidade, é hoje, em meus trabalhos, a mais forte presença entre os elementos formais da pintura. Daí o vazio ! Daí as paisagens de Monet, Pissarro, os prérenascentistas, os planos frontais de Velásquez e Rembrandt (A Ronda Noturna), de Matisse (o Ateliê vermelho, as grandes colagens) ou de Picasso (Guernica) me terem vivamente impressionado".

\section{O jardim ${ }^{297}$}

“Outra coisa importante para meu trabalho é esse jardim, é a natureza ao redor do meu ateliê, em torno de mim. Não trabalho sobre ela, nem com ela. Trabalho, creio eu, à maneira dela. Como se o processo de germinação das flores revivesse, se equivalesse ao processo de elaboração de meus trabalhos. O resultado final não é narrável, não é reflexo de nada, e sim um novo ambiente com nova significação.”

\section{A sensibilidade para a $\operatorname{cor}^{298}$}

"Eu nunca tive dificuldade com esse negócio de cor, de desenho, desde criança. Impressionante, eu era bom, sempre bom: ganhava sempre nota cem em desenho. Em qualquer tipo de desenho: observação, técnico, natureza morta etc. Foi uma coisa interior que nasceu comigo, mas teve esse lado do aprendizado, do contato com as 
coisas. Eu me lembro perfeitamente, que no jardim infância, quando eu tinha seis anos, havia uns envelopes. Eram uns envelopes que continham umas folhas coloridas: amarelo, vermelho. Também havia uns pauzinhos e umas fitas cortadas. A gente passava os pauzinhos e as fitas pelo papel, meio tecelagem. (Sued gesticula para ilustrar o movimento). Isso deve ter me marcado muito. Olha aqui (Sued aponta para seus quadros cuja superfície colorida é cortada por faixas ou pintadas em outro tom, ou coladas em outro material). Estranhíssimo isso. Depois eu cresci um pouco, fiquei adolescente e fazia estrelas com serpentinas aquelas fitas coloridas. Acho que tem relação.”

\section{Superfícies d'água}

Como Manet - que afirmou ter aprendido muito sobre pintura nas noites intermináveis quando observava o jogo de luzes e sombras da esteira do navio e durante os dias em que, debruçado no deck, fitava o horizonte ${ }^{299}$ - Sued citou, em muitas declarações, a importância da superfície d’água para a sua pintura. Em especial certa noite, numa viagem com seus colegas da faculdade, em 1947, na qual, da balaustrada de um navio, deslumbrou os reflexos da relva vindos dos fundos das águas do Rio Guaíba. Além disso, quando jovem, "pegava jacaré" no Arpoador. Ficava apoiado numa prancha de madeira, boiando enquanto esperava a onda certa. Olhava o "mar: aquele espanto". Extasiava-se com as ondulações da superfície, o horizonte, a linha do horizonte, o lugar no qual o mar encontrava com o céu, "o espaço: aquele vazio".

Ele afirmou que ter observado as superfícies d'água, à noite, pode ter aguçado sua sensibilidade para os tons sombrios. Disse: 
"As ondulações da superfície realmente criam um clima, criam um espetáculo de luz e sombra. E nessas sombras, muitas vezes eu percebo a presença do negro e do preto. A nossa sombra, o nosso escuro é diferente do escuro da Europa, por exemplo. A presença do negro é muito mais evidente aqui na América do Sul”.

\section{A primeira viagem para Paris}

Entre 1951 e 1953, Sued ficou em Paris. Conforme comentou com Lucia Carneiro e llana Pradilla: "era o auge do existencialismo. O preto dominava tudo, por toda parte.",300

"Bom, realmente era o que eu presenciava todos os dias. Eu saía: preto. Primeiro a paisagem: o que eu via era realmente muito sombrio. Com a falta de luz, causada pelo racionamento. Pela dificuldade de ter saído de uma guerra terrível, Paris foi uma cidade não-luz. Naquela época, realmente foi a cidade do escuro, da não luminosidade. Pretidão era constante nas fachadas dos edifícios.Muito além de estar danificada, a cidade se apresentava muito escura. Algo muito triste mesmo.Eu via e foi o que ocorreu. Por outro lado, repare que, naquela época, a moda era o preto. O preto era uma presença diária nas pessoas que lá viviam. Eu sentia isso. A Juliette Greco, por exemplo se apresentava, assim como a Edit Piaf também se apresentava, com roupas pretas.Naquela época, não sei se em sinal de luto, pois se tinha saído de uma guerra, não sei por que razão, mas de fato que a presença do preto era muito importante. Talvez o existencialismo também tenha influenciado. A filosofia do Sartre colaborou muito, muito, para que se adotasse o não-colorido.Eu acho que sim, é isso ai. Mas de qualquer maneira, me presenciou. Foi uma época importante, porque estávamos em Paris. Paris era a cidade criativa, grandes movimentos. Tudo lá surgiu: a arte moderna, cubismo etc. O preto era uma presença, porque era o tom da época”. 


\section{Cafés Parisienses ${ }^{301}$}

Nós freqüentávamos o Café Cujas. Um café que ficava no Quartier Latin, na Rue Cujas, que corta o Boulevard San Michel. Ficava cheio à noite, iam muitos brasileiros. Não eram somente intelectuais, mas turistas também. Conversava-se sobre tudo: poesia, cinema, pintura. Havia poetas, estudantes de filosofia, de cinema etc. Como o meu amigo o Ângelo de Sá que, estudava na Alemanha, com Heidegger, quando estava férias em Paris, encontrávamo-nos no café. Eu conheci o Rui Guerra, por exemplo, cineasta, angolano que depois veio para o Brasil.

As coisas aconteciam em Paris. Troca de livros e discussões sobre o texto, sobre poesia, Trakl, Holderlin e Rilke. Nós tínhamos conversas gerais, mas sem um intuito de formar algum grupo.

Aqui, no Vermelhinho, era a mesma coisa a mesma coisa. Encontrava-se com o Bruno Giorgi, o Portinari, Pancetti,etc. Mas, após os encontros, cada um ia para o seu lado.

\section{O uso do preto pelos mestres}

"Manet usava o preto com grande maestria, assim como Goya, Rembrandt e Velásquez também. Mas eu falei no Manet porque ele deu origem ao movimento moderno, ou seja, está muito próximo. Seu trabalho me lembra muito Picasso e Matisse, olhe os negros, olhe os contornos. Se você reparar, se você analisar, há uma presença, uma relação, uma coerência entre o trabalho de Picasso e o de Matisse com a pintura de Manet. Isso ninguém pode negar. O Manet, para mim, é o francês dos pretos!

Velásquez é realmente o senhor dos pretos. Impressionante, ele é impressionante! Cria uma superfície impressionante: não tinha nada ali, mas é um manto uma coisa uma chapada, negra. Picasso também. 
Matisse também usa muito preto. Sabe, o preto separa as cores, muitas vezes para valorizar as cores usa-se o preto, ou para separar, ou para rebaixar. Enfim, é uma coisa do pintor. Muitas vezes aparece um negro, o vazio. Às vezes o preto, com sobre-tons. Tem pretos com sobre-tom de verde, de vermelho. Como todos pintores Picasso também usava. Isso não é uma invenção minha.

\section{Preto em Mondrian}

"Funciona como qualquer cor, como o vermelho, o amarelo, o branco. Não tem nenhuma preferência. Serve para tensionar as cores, tal qual o branco, mas o branco cria menos tensão.”

\section{Pierre Soulages}

"Soulages, sua obra tem a presença de muito preto. Preto em extensão. Soulages é muito interessante. Vi uns trabalhos dele no Beaubourg. São trabalhos de força. Tem a presença do negro e do preto ali. E é abundante, praticamente o quadro preto, eu acho, preto. Ele é que o preto e o negro, eu não.”

\section{Sobre os pretos e negros dos americanos}

"Eu acho que o tal negro que eles usam é como o que todos os pintores usam. Não tem uma presença dominante, não é polarizante, não polariza nada. Pertence. Vive, vive igualmente com as cores. Há uma relação com todas as outras cores com o mesmo peso e não tem uma dominância, uma presença dominante da pintura. É uma cor como as outras.Nos americanos não vejo.”

\section{Pintura norte americana}

“Eu não, eu não sou muito ligado à pintura americana, por que eu fiquei muito em Paris. A Escola de Paris, La Ecole de Paris, era muito dominante. Era o que existia no 
mundo, incluindo Nova Iorque. Começava a aparecer a pintura americana, mas eles não eram o máximo, então, não era o tipo de arte que eu enfocava ou procurava.

Depois veio essa onda e tal. Eu olho como qualquer pintura, mas não vejo nada de extraordinário. Não vejo, não consigo, nem mesmo o Pollock, eu o acho somente curioso, só curioso..."

\section{A prática da gravura em metal}

Ao ser questionado, Sued concorda que a prática da gravura em metal pode ter afinado sua sensibilidade para os diversos pretos:

“A gravura em metal realmente foi uma paixão minha. Eu, de fato, senti já na Europa esse desejo de fazer gravura. Comprei até um livro do Hayter ${ }^{302}$, que era um gravador e professor de gravura inglês. Quando eu voltei para o Brasil, procurei então o Darel $^{303}$, que era amigo do Iberê. Eu disse que eu estava interessado em fazer gravura em metal, e ele me levou ao Iberê, na Lapa. Na verdade, eu havia conhecido o Iberê antes de eu ter ido para Paris. Ele tinha chegado recentemente da Europa, quando o visitei em seu ateliê. Bem, eu fui para Europa, passou-se o tempo. Quando voltei, o procurei por intermédio do Darel.

O Iberê era realmente competente. Havia estudado gravura na Itália. Ele me ensinou tudo sobre técnica: água-forte, água-tinta, maneira-negra, vernizes, mordentes etc.

Eu comecei a freqüentar o ateliê do Iberê, fazia gravura. De fato o preto tem uma presença marcante. Porque era preto e branco, quero dizer, a gravura em metal pode ser feita em cores. Mas inicialmente eu me dediquei, com paixão, à gravura em preto e branco. A gravura em metal era realmente apaixonante. Uma riqueza de técnicas, a diversidade, as possibilidades de expressão. Tudo isso é bem possível com a gravura em 
metal. Ela é mais rica, em minha opinião, que todas as outras modalidades de gravura como serigrafia, a litografia, a xilogravura. A gravura em metal, não digo que fosse a mais trabalhosa, mas, exigia muito fisicamente de mim.

Exige uma precisão técnica, além da visão. É preciso ter uma visão bem rigorosa. A visão tem de estar clara. O olho precisa estar muito atento, porque se trabalha no escuro. No começo da gravura em metal na água forte, por exemplo, se passa o verniz preto. Você trabalha sobre um muro preto. Você precisa ter um olhar afiado. Um olho físico afiado para desenvolver o seu trabalho. É um esforço muito grande. A tal ponto que Morandi, por exemplo, deixou-a, depois de certo tempo. Ele fazia muita água forte, somente água forte praticamente. Depois ele abandona a gravura. Quando lhe perguntaram por que, ele disse que o olho não estava mais acompanhando. Ele fazia muito aquele hachurado, aquela maneira do seu traçado exige muito..

Fazendo gravura, a presença do preto e da luz: o branco, começam, então a aparecer em mim”.

\section{Biblioteca Municipal de São Paulo}

Algum tempo depois, em 1957, Eduardo Sued foi para São Paulo. Freqüentou a Biblioteca Municipal, onde consultou com "avidez sua coleção de livros técnicos, a cozinha da pintura." ${ }^{304}$

"Eu era obcecado pela pintura, pela técnica da gravura, da pintura. Eu lia todas as fórmulas, ou a receita, digamos assim, de vernizes, de diluentes, de preparação de tela, dessas coisas da cozinha da pintura. Eu ficava apaixonado, eu tinha anotado tudo, tudo. Os tecidos, a questão dos tecidos todos: dos linhos, lonas. Enfim, um mundo fantástico. A cozinha da pintura é monumental. Além disso, li sobre as técnicas dos mestres: El Greco, Tintoretto, Tiepolo, Rembrandt etc. Eu achava que eu precisava de tudo isso. De 
fato me foi útil. Com o tempo, eu fui me decantando, simplificando. Mas, de qualquer maneira, a base técnica me foi dada nessa Biblioteca Municipal."

\section{Bons livros de técnicas}

"O livro do Doerner, Max Doerner e o do Ralph Meyer. Tinha muitos outros, mas basicamente esses dois eram muito interessantes. Eu tenho os dois livros ainda: Ralph Mayer e Max Doerner!"305

\section{Livros escritos por artistas}

"Tive contacto com o Paul Klee numa livraria. Quer dizer, com a sua obra, na Livraria Francesa, que ficava atrás do Copacabana Palace. Eu morava e nasci em Copacabana. Gostava dessas livrarias. Eu nasci desta maneira gostando de ler, gostando de ver. Na livraria francesa, por volta de 1948, vi uma brochura: era uma conferência que Klee havia dado na Suíça. Eu o li muito. Tenho-o até hoje. O Klee foi muito importante no meu começo, assim como foi Picasso. Depois eu comprei outros livros, como de Bauhaus. Na época, não havia no Brasil muito livro escrito por artista. Meu contato com os escritos de Matisse foi muito depois, depois de velho, não na fase de minha formação. Tive contato muito mais tarde.

Eu lia, mas também eu via. Havia a grande livraria Askanasy, no centro. Sabe que as livrarias na época eram importantes. Como não havia galeria, nem mercado existia esse negócio de mercado é coisa nova -,então essas livrarias eram importantes. Askanasy por exemplo, ou a livraria Freitas Bastos, muitas livrarias faziam exposição de artista. Num cantinho assim, um coquetelzinho, uma coisa. Mas o mercado não existia. Vendas: somente entre amigos. Os amigos é quem comprava. Não existia mercado. Hoje, ao contrário, essa garotada só pensa em ter o mercado. O importante é amar as coisas: nos éramos amadores. Não éramos propriamente pintores. Éramos 
pintores amadores. Gostávamos. O ato de gostar, de ficar dentro. E assim foi. Conheci várias pessoas. Milton Dacosta, importante. Conheci Volpi também.”

\section{Milton Dacosta}

"Milton da Costa. Eu achava aquela pintura construtiva espetacular. Ele foi presente, ele realmente foi um dos que me orientaram intelectualmente. Eu o adorava. Também gostava dele como pessoa. Eu o conhecia. Morava ali na perto da Nossa Senhora e Silva. Ali na Praça Nossa Senhora da Paz. Eu passava sempre lá. Porque eu morava ali na Lagoa, aliá, aainda moro. Era pertinho, eu ia todo o dia. Ele era uma figura, uma figura de artista. Coisa rara hoje.

Ele conseguia com aqueles quadros pequenos uma dimensão enorme. $\mathrm{O}$ tamanho ótico era diferente do tamanho métrico. É como Morandi. É a mesma coisa. Morandi trabalhando em pequenos formatos, no entanto, com aquela expansão.. Morandi: quadro pequeno, porém gestual imenso. Tem gente que precisa ter quadro grande, gestos largos, e ele, com aqueles quadros pequenos, movimentos curtos, cria algo grande. Milton também, a mesma coisa: quadro pequeno, mas obra enorme."

Sobre o uso que Milton fazia do preto, Sued disse:

“Também usou, mas não foi seu forte não. Usou preto, preto e branco, mas naquela época não havia isso. Usava o preto como cor, uma cor como o vermelho, o amarelo. Tem alguns quadros, mas também tem quadro vermelho, tem quadro branco.

Milton foi uma grande figura que eu conheci. Assim como o Sérgio Camargo também. Sérgio foi amigo. Fui amigo do Milton, da Maria Leontina, do filho deles, que é ator de teatro e cinema, o Alexandre Dacosta." 


\section{Fotos em branco e preto de Geraldo de Barros}

"Eu conheci o Geraldo muito antes de ir para a Europa. Eu conheci aqui juntamente com o Mavignier, Almir Mavignier,com o Ivan Serpa, o Abraão Palatinik, essa turma toda, o Mário Pedrosa que era o cabeça. Fazíamos parte de um grupo, não é bem grupo. O Geraldo era um pouco mais velho que eu. Ele me ensinou,como se diz,você calca o papel sobre uma tinta. Como é que se chama? Ele me ensinou algumas técnicas de pintura, me ensinou muitas coisas... Vinha muito de Klee,porque ali realmente havia o Klee no fundo. Geraldo me ensinou muitas coisas sobre a questão dos materiais, sobre explorar as possibilidades de todo material, de qualquer material. Por exemplo,cera: eu passava no papel e depois passava uma tinta por cima. A cera impedia a tinta de entrar no papel.Depois passava a gilete, tirava a cera. Enfim, essas maneiras, esses procedimentos técnicos. O Geraldo era do grupo e realmente eu me ligava muito a ele.

Houve uma ligação muito interessante com o Geraldo, conversas sobre a parte técnica das pinturas, sobre as colagens. Ele me falou algumas coisas. Eu sempre acompanhei o trabalho do Geraldo, assim como acompanhei o Almir. Eu acho os trabalhos do Geraldo sempre interessantes. Apesar dos períodos que ele não se manifestava, não mostrava trabalhos. Sempre admirei muito. Eu acho muito bom seus pretos, mas seu trabalho não me influenciou diretamente.

Eu fui morar em São Paulo, Geraldo tinha uma loja na Praça da República, era uma loja de design. Ele era muito envolvido com a Bauhaus,esse movimento do Gropius.

Ah, sim. Falávamos muito, naquela época a Bauhaus era importantíssima. Um fato de primeira ordem que influenciou. A Bauhaus era uma presença permanente naquela época. Ela deu origem ao construtivismo aqui no Brasil, ao concretismo etc. 
Isso tudo partiu da Bauhaus, de Gropius, Klee, Kandinsky, todos. Também importante para nós, além da Bauhaus que era dominante, era a Ècole de Paris: Picasso, Matisse, Braque. Então era uma época muito criativa, aconteciam mil coisas.

\section{Poesia $^{306}$}

"Para mim, poesia foi de fato um fomento importante."

\section{Noites e escuridões em verso ou prosa}

"Eu admiro muito o Georg Trakl ${ }^{307}$. Eu tenho a impressão de que ele lida muito com esse clima do oculto, do escuro, do não dito. Isto me fascinava muito. A questão do crepúsculo, da tarde, do noturno ou mesmo da escuridão. Eu sinto que essa questão do sombrio, do escuro, é uma presença em mim. Por isso que talvez o negro, que é a suprema escuridão, o negro, seja tão caro a mim. Tem aquele lado, o lado do mistério, do desconhecido, do que está atrás. E isso e é um mistério. Isso me fascina muito, porque no fundo a arte é um mistério."

\section{Tenebroso é belo ou sublime?}

Sued revelou a lleana Pradilla e Lúcia Carneiro não saber definir o belo. Que a palavra em si não lhe transmitia um conteúdo inequívoco. Que não existe padrão de beleza. Mas, em sua opinião, "tudo que conduz ao deslumbramento é belo." "O belo, independente de qualquer ideal, pode, portanto, se revelar mesmo através do tenebroso!" 308 .

O tenebroso não estaria mais relacionado ao sublime que ao belo?

Deslumbramento que nos leva ao encantamento é encontro ou comunhão consigo mesmo, é solidez do ser, é ato belo, estado de beleza. 
O grandioso ou supremo encantamento é o sublime: o pôr do sol, as cintilações nas ondas do mar, a "Ronda Noturna" de Rembrandt ou o orgasmo são eventos belos.

Deslumbramento que leva ao medo, ao terror é fragmentação, corrupção do ser, é ato perverso ou estado de terror: crocodilos gigantes invadindo Nova York, uma aranha projetada num grande telão, tsunami devastador ou cobra devorando cobra........serão certamente eventos de terror !!

Uma onda gigante pode despertar medo ao surfista ou, ao "pegá-la", ser causadora de forte emoção -- um indefinível encantamento. .

O tenebroso pode ser aparição do belo (o carro alegórico As Trevas do carnavalesco Joãozinho Trinta, da escola de samba Unidos do Viradouro - carnaval, Rio, 1997 , e um ambiente preto / negro de Soulages , são bons exemplos )

O tenebroso pode ser também a aparição da destruiçâo.......... da morte !

\section{Pintura e Música:}

Sued freqüentemente usa a música como metáfora para as relações cromáticas. Compara os intervalos, acordes, dissonâncias, os contrapontos e harmonias da música às diferentes luminosidades, saturações e extensões das cores $^{309}$

“De fato, existe uma relação muito grande entre a música e a pintura. Às vezes eu fico ouvindo música e fico pensando nos valores de claro e escuro, luminosidade, na distancia entre um acorde e outro. Eu vejo como se tivesse vendo uma pintura. A presença do contraponto na pintura. Há algo que passa independente das coisas que estão diante. Como se houvesse outras coisas que não estão diante de nós, mas que no entanto se harmonizam. É esse contraponto que eu vejo na pintura. É engraçado, são 
termos parecidos, existe uma analogia de fato entre a pintura e a música. Eu vejo tudo isso, timbre das cores, timbre dos instrumentos, valor, tonalidade. Tudo isso existe tanto em um quanto em outro. Muitas vezes eu faço uma leitura de uma música, digamos, eu ouço uma música, só observando esses detalhes, essas especificações. Eu acho bem interessantes esses objetos que existem na música."

\section{Nessa analogia o que seriam os pretos e os negros? $?^{310}$}

"Nesse caso, eu poderia dizer que o negro e os pretos seriam a tuba. Mas, se não for para associar a algum instrumento. Em outro sentido, o negro seria a ausência, não o vazio, seria a ausência de sons. A ausência, os intervalos mudos. Seria a mudez, isso seria o negro. A mudez seria o negro.”.

\section{E os pretos, há uma diferença entre os dois?}

"Há sim. Há uma diferença grande entre os dois. O preto é um som de fato, não é uma ausência. É uma presença mesclada, sem cromatismo. Digamos assim, olhando a música, há momentos sem cromatismo, são aquelas passagens não definidas, sem cor. Isso seria o preto. Na música, às vezes ouvem-se umas passagens sem cor, isso seria o preto. O negro seria, então, aquele vazio imenso. No qual você pudesse mergulhar e não encontrar algum fundo."

Antes de ir para a Europa, Sued teve aula de pintura com um pintor expressionista que era violinista.

"Antes de eu ir para Europa, Henrique Boese chegou da Alemanha. Tocava violino. Chegou da Alemanha, casado com uma médica brasileira. Eles foram morar em Santa Teresa e ele então ele começou a dar aulas. Fui eu e o Almir Mavignier. Fomos a esse curso todos os sábados. Nós íamos lá, fazíamos uma ou outra coisa qualquer, levávamos trabalhos. Ele comentava, no fim da aula, sobre o que tinha sido feito 
durante o dia. Henrique Boese era um pintor, pintor em Santa Teresa, e também tocava violino.

\section{Boese fazia essas relações entre música e pintura?}

"Não, não. Nada, nada. Isso era uma coisa particular dele. Nós sabíamos, mas ele não falava."

\section{Matisse comparou o uso do preto a um contrabaixo, que chegou a fazer solos. ${ }^{311}$. A qual instrumento Sued compararia o preto, e o negro?}

"Pois é, ele falou em contrabaixo, tudo bem. Pode ser contrabaixo também, pode ser contrabaixo. Há uma associação e pode dizer isso tuba e tem outros, tem uns fagotes. As madeiras de um modo em geral se ligam mais aos pretos Tem os fagotes, mesmo o oboé, corne inglês, Não sou músico, não. Mas eu estou falando de música. Os instrumentos se ligam, lembram as cores. Os brancos lembram as clarinetas. Os brancos, aquela coisa, as cornetas se ligam muito aos brancos. $\mathrm{O}$ preto pode ser um instrumento, mas o negro, para mim, é a ausência de tudo, o silêncio."

\section{A paleta de Sued ${ }^{312}$}

"Minha paleta não é ortodoxa e lembro que procurei as cores vibrantes quando meu pai morreu"313.

"É sim, é verdade"

\section{A paleta o funciona sempre como contraste do estado emocional?}

Pode ter funcionado naquele caso. Foi uma fase difícil. Eu ia ao hospital do servidor do estado, aquilo era cinza, somente cinza. Então, quando eu saía, eu queria ver cores. Eu saía e queria ver um edifício colorido, vermelho. Eu queria ver uns planos, umas áreas imensas de cor. Evidentemente eu acho que naquele momento havia uma 
reação ao estado emocional. Era uma maneira de reagir àquele estado emocional. As cores exuberantes negavam o estado não colorido interior. Pensava "eu não quero mais isso, não, eu já estou cansado”. Era uma reação contra. Mas é possível que haja outro tipo de relação.

\section{Pretos e negros}

“Aqui e agora, não tem nada. É outra coisa, talvez tenha uma conotação mais filosófica. Talvez o pensamento. Não tem o emocional, não vejo muito. Está mais ligado a um pensamento do vazio."

\section{Este vazio tem relação ao conceito budista de suniata, o vazio produtivo?}

“Tem muito a ver. Vazio sem nada dentro não é vazio. É contraditório dizer isso. Se é vazio não pode ter nada dentro, mas eu digo: vazio, se não tiver nada dentro, não é vazio. Veja é bem diferente. É um vazio construtivo, germinativo. É ai que importa. É isso que interessa. Não o vazio vazio, o vazio nada não é isso. É um vazio cheio, vazio vivo, germinativo..

\section{Qual a diferença do vazio do prata para o vazio do preto ou negro?}

Sued havia declarado anteriormente que "o prata é o vazio, mas um vazio que é o lugar de alguma coisa, e contém a presença do invisível. (...) Por repudiar algumas cores e conservar outras, o prateado - um autista muito exigente - instaura a ordem na tela." ${ }^{314}$

"Do prata? Existe uma diferença de fato. Como é que foi na época, na época o prata era o vazio. Eu acho que os dois são vazio. O prata é um vazio invisível. O negro é um vazio presente, visível. Não sei se visível seria a palavra. O negro é o vazio que você sabe que está com ele. Já o prateado é o vazio que foge, que você não sente a presença. 
No prateado, é um caminhar solitário, enquanto no negro é um caminhar engraçado, vitalizado. Se bem que eu falo há vitalidade nos dois. Porém, no negro, estranho, eu acho que no negro há um diálogo. $\mathrm{O}$ autista realmente é muito prateado. Não se liga. Eu acho que com o prata estou desligado. É um desligamento, o invisível, nada sei. Com o negro, ao contrário, é um ligamento, fecundação. O negro eu vejo a fecundação e no prateado a ausência disso, é outro vazio.”

\section{Experimentações}

Sued declarou não hesitar em infringir as relações do todo, reverter os procedimentos habituais da técnica e/ou adotar novos materiais, pois experimentar é aceitar o desafio da dúvida ${ }^{315}$. Nessas experimentações, como se comportam os pretos?

"Exato. O Klee me ensinou muito nesse particular. Permitiu que eu pudesse usar qualquer coisa, qualquer objeto, qualquer ferramenta. Desde que você esteja dentro da criação, você pode usar o que você quiser: régua, compasso, qualquer cor. Tudo está a seu alcance, qualquer coisa colagem, colar papel é livre. O sentido da liberdade em Klee é muito importante. Eu aprendi, tanto que, até hoje, se eu estou produzindo, e se quero colar alguma coisa ali, eu colo barbante, eu colo um tecido, eu colo um papel. A liberdade, a criação permite que se use o que você quiser desde que você prossiga, desde que você se aprofunde nela mesma, nessa criação. Qualquer coisa que te ajude a ir mais fundo."

\section{Como variam os pretos e negros ao mudar a tinta, o suporte?}

“Acho, de fato, que a presença do negro me é dada através da presença de um elemento novo material. Um tecido brilhante negro que eu colo, eu introduzo esse negro. Ou então, eu pinto o negro na própria tela, ou colo alguma coisa negra ou preta. 
Há tecidos negros, outros pretos também. Eu acho que o preto e negro estão presentes sempre. Muitas vezes não de uma maneira dominante, mas como um elemento de harmonia, de coesão apenas."

\section{Como Sued consegue o negro na pintura?}

Existem certos materiais que têm um caráter negro. $\mathrm{O}$ esmalte, por exemplo. Repare que, mesmo nos tubos de tinta vendidos no comércio, há diversos negros: negrode-marte, negro-de-marfim, negro-de-pêssego etc. São tantos. É uma diversidade muito grande. Há sub-tons, nuances em cada um deles. O negro é mais negro, é o negro puro, digamos assim. É aquele que não tem nada dentro de si, nada, nenhuma cor, nenhuma tonalidade. Ele é apenas ele mesmo. Por isso ele é verdadeiro, por isso ele é o grande escuro. Às vezes, o negro é dado pelo material mesmo. Já o branco é diferente, tem uma passagem que eu falo como conseguir o grande branco, eu falo em Rembrandt, não sei se você leu essa passagem ${ }^{316}$. O branco-de-prata é o mais branco desses materiais. Como é que você vai conseguir mais branco que o branco-de-prata? Não existe nenhum material que possa ser mais branco que o branco-de-prata. É no contraste, na entourage, no que está em volta e que faz com que o tal branco fique mais branco. Já no negro não existe isso, não tem isso, não adianta entourage, que é ele mesmo. Ele é independente. O negro é o buraco negro, absorve tudo ele. É ele mesmo. É difícil distinguir. Ali por exemplo, (Sued aponta para um quadro feito com esmalte sintético e óleo), há o negro espelhado e o preto do lado. Está evidente aquilo ali. É a qualidade, o próprio material, que distingue um do outro pela própria escuridão,

\section{Brilho das superfícies esmaltadas ${ }^{317}$}

"O brilho ofuscante do esmalte é uma propriedade secundária, não é relevante. $\mathrm{O}$ que importa no esmalte ,quando eu falo do esmalte, é o negro. O brilho não tem nada a ver, é acidental. Para mim, o brilho ofuscante, o brilho que atrapalha a visão mais direta 
do negro, não importa porque é um acidente físico. O negro, isso que está oculto dentro dessa situação criada pelo esmalte, é o que importa. Digamos assim, o brilho que ofusca não é relevante, é secundário. O que importa é o negro.”

\section{A dificuldade de conseguir o negro com tinta acrílica}

“Com acrílico é difícil. É muito difícil. Tem um negro mais intenso, que é vendido, chamado negro mais intenso. É o carvão puro, pode-se trabalhar como negro. É o carbono."

\section{Suporte da pintura.}

"O suporte da pintura... Eu usava linho, hoje, eu uso lona preparada, comprada pronta. Antes, eu fazia, preparava o fundo. Era muito trabalhoso. Hoje, já encomendo. Vem a tela e tal. Eu trabalho. Não faço mais nenhum tratamento ao fundo. Eu começo logo a pintar, colocando as primeiras cores, depois umas cores começam a chamar outras. A gente vai então caminhando. Com relação ao suporte, pode ser a madeira também. Eu comecei a fazer "pintura-relevo", eu chamo de pintura-relevo é onde há a junção da tela com madeira. Juntando tudo, o suporte passa a ser diferente: é tela e madeira. Pinta-se sobre esses elementos, é apenas isso, Pode pintar sobre papelão, sobre Eucatex, sobre o que quiser. Como disse Klee, ou melhor, como ele mostrou, você é livre, você pode pintar com o dedo se quiser."

\section{Instalações feitas com tecidos}

Em diversas instalações Sued usou tecido, tanto em 1984, na XLI Bienal de Veneza, Itália, quanto em "entorno de HO, no em 1998, no Centro de Arte Hélio Oiticica.

“Tecidos foram escolhidos por mim, já a priori. Já havia decidido que usaria tecidos. Escolhi esse negro aqui, essa seda aqui. Procurei um material que fosse o mais 
escuro possível. Encontrei um preto, a seda italiana, então, coloquei aquele tecido negro. Em Veneza tem esse negro com outras cores do lado. Seda também. Os tecidos são escolhidos assim: eu vou na loja e vejo qual o preto mais preto, mais escurão, mais escuro e o elejo como sendo o negro".

O jogo entre o brilho e a opacidade dos quadros pretos e negros, cuja fatura é gorda encrespada, e a vibração da superfície ordenada por pinceladas teriam relação com esse brilho dos tecidos?

"O tecido tem esse brilho quando a gente se move."

\section{A loja de armarinho}

Durante a infância e juventude, Sued teve contato com tecidos por intermédio da profissão do pai. Haveria algum eco desses tecidos na pintura?

"Naquela época, as lojas chamadas de armarinho eram lojas grandes. Havia os balcões repletos de gavetas. Vendiam-se linhas, agulhas, cadarços, e mais não sei o quê. No salão, havia aquelas torres com tecidos. Tecidos que pendiam jogados. (As mãos de Sued movimentam-se, mimetizando a caída ondulante do pano). Era interessante. Ainda existe isso, existem lojas com panos que caem. Então acho que teve uma presença: as cores, as variações de cores naqueles tecidos. Teve uma presença, eu morei ali, eu vivi ali. Pai imigrante, questões de família, então a gente ajudava na loja. Eu vendia coisas cadarço, tecido etc. Isso afina o olho. É um aprendizado também.” 


\section{Notas}

${ }^{295}$ A não ser que diferentemente indicado, as citações em itálico foram extraídas das entrevista realizada em 25/11/2008

${ }^{296}$ Conversa telefônica em 17/12/2008

${ }^{297}$ Conversa telefônica em 17/12/2008

${ }^{298}$ Entrevista realizada em 25/11/2008.

${ }^{299}$ WILSON-BAREAU, Juliet (Editor), Manet by Himself Boston: Chartwell Books , 1992, p. 26

1850- anotado por Charles Toché

${ }^{300}$ SUED, Eduardo Eduardo Sued, entrevista a lleana Pradilla e Lúcia Carneiro, coleção palavra do artista. Rio de janeiro: Lacerda, 1998 p. 9

${ }^{301}$ Conversa telefônica em 19/12/2008

${ }^{302}$ Stanley William Hayter, pintor e gravurista inglês,escreveu "New Ways of Gravure", cuja 1 ${ }^{\text {a }}$ edição saiu em em 1949 e posteriormente escreveu "About Prints", publicado em 1962.

${ }^{303}$ Darel Valença Lins

${ }^{304}$ SUED, Eduardo Eduardo Sued, entrevista a lleana Pradilla e Lúcia Carneiro, coleção palavra do artista. Rio de janeiro: Lacerda, 1998 p.13-14.

${ }^{305}$ The Artist's Handbook of Materials and Techniques, traduzido em português como "Manual do Artista de Técnicas e Materiais" do Ralph Meyer e "The Materials of the Artist and Their Use in Painting: With Notes on the Techniques of the Old Masters," de Max Doerner., sem tradução em português.

306 "O gênero narrativo provoca a sensação de se estar no mundo, na reflexão dele. O poema, por sua vez, deixa a impressão de se estar com o mundo, na construção dele. As leituras poéticas pareciam me dar a consciência de ser um dos mortais responsáveis pela construção do munso, isto é, um dos seus co-autores" in SUED, Eduardo Eduardo Sued, entrevista a Ileana Pradilla e Lúcia Carneiro, coleção palavra do artista. Rio de janeiro: Lacerda, 1998 p. 29

${ }^{307}$ Georg Trakl (1887-1914), poeta austíaco considerado um dos grandes expoentes da poesia expressionista alemã.

${ }^{308}$ SUED, Eduardo Eduardo Sued, entrevista a lleana Pradilla e Lúcia Carneiro, coleção palavra do artista. Rio de janeiro: Lacerda, 1998 p. 54

${ }^{309}$ Por exemplo,Sued afirmou:

"Ao ouvir música, vejo-me ligado aos seus intervalos, acordes e dissonâncias, aos seus contrapontos e harmonias. Tento promover em mim mesmo essa vivência através das cores, em suas diferenças de luminosidades, saturações e silêncios. Os silêncios cromáticos, por exemplo, se referem às séries branca, cinza e preta." In SUED, Eduardo Eduardo Sued, entrevista a lleana Pradilla e Lúcia Carneiro, coleção palavra do artista. Rio de janeiro: Lacerda, 1998 pp. $22-23$

$\mathrm{Ou}$,

"Não se trata de uma correspondência entre uma escala musical qualquer e as cores, de tal modo que pudéssemos construir uma espécie de escala cromática, menos ainda da audição de sons através das cores. Isto mostraria, por certo, a fraqueza do próprio sistema plástico. Ouvir as cores é simplesmente uma metáfora: é vê-las livres das exterioridades, num concerto radical e emergente de luz, A analogia de um outro sistema (musical/plástico) não é senão aquela das relações essenciais e vivas dos elementos (sons/cores) que existem em cada um desses 
sistemas." In SUED, Eduardo Eduardo Sued, entrevista a lleana Pradilla e Lúcia Carneiro, coleção palavra do artista. Rio de janeiro: Lacerda, 1998 p. 60-61

Em outra declaração:

"Costumo ouvir as cores para poder fazer a estrutura cromática das telas. As cores falam muito baixo e por vezes demoram até a falar. O pintor precisa trabalhar com os ouvidos para escutar as exigências das telas. Quando estou em dúvida a respeito de um trabalho, fecho os olhos e aproximo o ouvido da tela. As cores servem para serem vistas e ouvidas" Entrevista em $O$ Globo, 2 de outubro de 1989, citado em CANONGIA, Lígia (org.) Eduardo Sued, São Paulo: Cosac Naify, 2005 p. 186-187

310 "Os silêncios cromáticos, por exemplo se referem às séries branca, cinza e preta, Acho que existem presenças distintas de silêncio e, portanto, um conceito de silêncio". SUED, Eduardo Eduardo Sued, entrevista a lleana Pradilla e Lúcia Carneiro, coleção palavra do artista. Rio de janeiro: Lacerda, 1998 p. 23.

311 "Como toda a evolução, a do preto na pintura se fez aos solavancos. Mas desde os impressionistas parece tratar-se de um progresso contínuo, de uma participação cada vez maior na orquestração colorida, comparável à do contrabaixo que chegou a fazer solos". MATISSE, Henry: Matisse escritos e reflexões sobre a arte São Paulo: Cosac Naify, 2007, p. 226, nota65

312 "Hoje, o leque de cores é bastante aberto e elas são chamadas à medida que o trabalho necessita. Basicamente utilizo magenta, vermelho-de-cádmio claro, vermelho púrpura,ocrevermelho,terra-de-Siena queimada, vermelho-de-Veneza;amarelo-de- cádmio, laranja,ocreamarelo,verde-esmeralda,verde-veronese, azul-altramar claro,azul-cobalto claro, azulturqueza, azul-da-Prússia,violeta-cobalto claro,preto-marfim,preto-de-marte,branco-titânio e branco-de-zinco.

Este conjunto, selecionado a partir do mostruário de cores vendidas pelo comércio, constitui o que chamo palheta física do artista. A palheta real é, porém, indefinida. É o conjunto de suas cores, obtidas a partir daquelas. Essas novas cores não tem nome. "In SUED, Eduardo Eduardo Sued, entrevista a lleana Pradilla e Lúcia Carneiro, coleção palavra do artista. Rio de janeiro: Lacerda, 1998 p. $42-43$

${ }^{313}$ Declaração dada ao jornalista Antonio Gonçalves Filho, em maéria publicada no O Estado de S. Paulo, 21 de outubro de 1999. Citado em CANONGIA, Lígia (org.) Eduardo Sued, São Paulo: Cosac Naify, 2005 p.179.

314 "O prata é o vazio, mas um vazio que é o lugar de alguma coisa, e contém a presença do invisível. O vazio vitalizado representa as coisas sem gravidade e sem peso, e foi se estendendo como uma potência na tela. É como se eu estivesse lidando com entes invisíveis e ausentes. Por repudiar algumas cores e conservar outras, o prateado - um autista muito exigente - instaura a ordem na tela"

"Eduardo Sued declarou em depoimento publicado em O Globo, 30 de junho de 1997) Citado em CANONGIA, Lígia (org.) Eduardo Sued, São Paulo: Cosac Naify, 2005 p. 190.

${ }^{315}$ In SUED, Eduardo Eduardo Sued, entrevista a lleana Pradilla e Lúcia Carneiro, coleção palavra do artista. Rio de janeiro: Lacerda, 1998 p. 56

316 "Quanto à cor branca, quando situada em contexto branco, é menos luminosa e menos intensa do que o mesmo branco em contexto sombrio. A virtude de se chegar ao branco mais luminoso e mais intenso que o branco da tinta advém de sua vizinhança. Eu me lembro, em 1952, no Museu do Prado (Madri), da forte impressão que me causou o branco intenso e luminoso da sobre-saia da Artemisa de Rembrandt. Ao contrário do negro, essa superfície de cor branca não permite a penetração do olhar. A superfície branca, independente de qualquer vizinhança, é opaca."

In SUED, Eduardo Eduardo Sued, entrevista a lleana Pradilla e Lúcia Carneiro, coleção palavra do artista. Rio de janeiro: Lacerda, 1998 p. 45-46

${ }^{317}$ Conversa telefônica em 19/12/2008 